UNIVERSIDADE DE SÃO PAULO

FACULDADE DE FILOSOFIA, LETRAS E CIÊNCIAS HUMANAS

DEPARTAMENTO DE HISTÓRIA

PROGRAMA DE PÓS-GRADUAÇÃO EM HISTÓRIA ECONÔMICA

DANILO BAROLO MARTINS DE LIMA

\title{
O DEBATE SOBRE O TRATADO DE COMÉRCIO BRASIL-ESTADOS UNIDOS (1935): \\ Classes, Estado e Projetos para o Brasil
}




\section{UNIVERSIDADE DE SÃO PAULO}

FACULDADE DE FILOSOFIA, LETRAS E CIÊNCIAS HUMANAS

DEPARTAMENTO DE HISTÓRIA

PROGRAMA DE PÓS-GRADUAÇÃO EM HISTÓRIA ECONÔMICA

\section{O DEBATE SOBRE O TRATADO DE COMÉRCIO BRASIL- ESTADOS UNIDOS (1935):

\author{
Classes, Estado e Projetos para o Brasil
}

DANILO BAROLO MARTINS DE LIMA

Dissertação apresentada ao Programa de

Pós-graduação do Departamento de História da Faculdade de Filosofia, Letras

e Ciências Humanas da Universidade

de São Paulo, para obtenção do título de

Mestre em História Econômica.

Orientadora: Profa. Dra. MARISA MIDORI DEAECTO

SÃO PAULO

2014 
Aos meus pais e à Thaissa 
História é passado e presente, um e outro inseparáveis.

Fernand Braudel

É que cada nova classe que assume o lugar daquela que antes governava é compelida, a fim simplesmente de levar a cabo seus objetivos, a representar seu interesse como o interesse comum de todos os membros da sociedade (...), tem de dar a suas ideias a forma de universalidade, representando-as como as únicas racionais e universalmente válidas.

K. Marx e F. Engels 


\section{AGRADECIMENTOS}

Há muitas pessoas a agradecer pela contribuição dada, não apenas para a elaboração desta dissertação, mas também para minha formação, como pesquisador e

historiador. É tarefa impossível lembrar-me de todos, e certamente alguns que muito mereceriam menção podem ficar ausentes. Porém, isso se deve exclusivamente às minhas próprias falhas de memória. Devo, portanto, agradecer primeiramente, de forma coletiva, aos vários professores, colegas e amigos, com os quais pude inúmeras vezes dialogar, discutir e aprender. Sem essas conversas, muitas vezes descontraídas, outras mais sóbrias, eu nunca poderia ter concluído este trabalho. Um pequeno, ainda que valioso passo no que espero, seja uma longa jornada.

Devo agradecer especialmente a alguns mestres que muito contribuíram para minha formação como historiador. O Prof. Dr. Lincoln Secco, que desde o princípio da graduação me recebeu em seu Grupo de Estudos de Fernand Braudel, a quem devo boa parte de minha introdução à História, à Historiografia e à obra de Braudel, sua visão totalizante e delicado trabalho de síntese. Também agradeço muito à Profa. Dra. Maria Lígia Coelho Prado, que me acolheu em seu grupo de estudos de História latinoamericana e relações internacionais, que nos conduziu por leituras riquíssimas e discussões teórico-metodológicas fundamentais para nossa formação.

Agradeço também imensamente aos meus colegas de grupos de estudos. Se há algo que aprendi em minha formação acadêmica é o valor inestimável das leituras dirigidas e debates que neles pude travar ao longo desses anos. No Grupo de Braudel, o Prof. Fábio, Apoena, Larissa, Helena, Vivian, Cristiano, e outros. Em nosso grupo latinoamericano, Adamastor, Ricardo, André, Fernando e Gustavo. No(s) Grupo(s) de Estudos de Marx, Flávio, Badaró e Jonas. Também aos colegas do atual Grupo de Estudos de História Econômica, sob a coordenação do Prof. Dr. Alexandre Saes.

Ao Prof. Dr. Wilson do Nascimento Barbosa, pelas aulas acerca de método, História contemporânea, economia e política. E pelas conversas que valeram mais do que aulas inteiras. Ao Prof. Dr. Ricardo Colistete, pelo incentivo e conhecimento compartilhado em História Econômica. Ao Prof. Dr. Alexandre Barbosa, pela orientação valiosa nos caminhos dos clássicos da historiografia e do pensamento social brasileiro. Agradeço especialmente ao Prof. Dr. Felipe Loureiro, pelos comentários críticos que muito me ajudaram a traçar novos caminhos para a presente pesquisa. E a vários 
professores que, não sendo diretamente ligados a meu campo específico de pesquisa, não deixaram de contribuir enormemente para a minha formação. São tantos que seria impossível aqui contemplar a todos.

E não há como deixar de mencionar todos os amigos com os quais tive conversas tão enriquecedoras nas salas, corredores e pátios dessa Universidade e que tornaram esse caminho mais alegre também. Edson, David, Jaeder, Samuel, Felipe, Leandro, Eliel e Natália, somente para citar alguns, entre tantos. Ao Ricardo, com quem tenho tido tantas interlocuções sobre o fazer da História e problemas do presente. Certamente não poderia faltar menção ao meu amigo e parceiro de pesquisas, Luiz Felipe Bruzzi-Curi, cuja colaboração intelectual e conhecimentos acerca da obra e do pensamento de Roberto Simonsen foram indispensáveis para a conclusão desta dissertação.

Agradeço aos meus pais (que são dois), minha mãe e ao meu querido amigo-pai Carlos Lungarzo, pelo apoio, carinho, paciência e exemplo, intelectual, ético e humano, pelas longas conversas e laboriosas revisões de trabalhos. A minha irmã, meu primo, a meu irmão, Vítor - músico e futuro historiador, e a meus amigos que sempre se mantiveram próximos. A meus colegas e amigos de trabalho. A minha querida esposa, Thaissa, que além do apoio constante, amor, companheirismo e paciência para lidar com minhas ausências, crises e problemas, bem como grande ajuda na escrita desta dissertação, me ofertou inspiração e um exemplo do que é ser uma cientista ética, focada, trabalhadora e brilhante.

Por fim, mas não por último, agradeço imensamente à minha orientadora, a Profa. Dra. Marisa Midori Deacto, pela orientação, pela correção minuciosa dos textos e pela paciência que tantas vezes demonstrou, ao longo deste meu proveitoso, ainda que por vezes difícil, caminho de aprendizado. 


\section{RESUMO}

Danilo Barolo Martins de LIMA. O Debate Sobre O Tratado De Comércio Brasil-Estados Unidos (1935): Classes, Estado e Projetos para o Brasil. [Dissertação]. Universidade de São Paulo, Faculdade de Filosofia, Letras e Ciências Humanas. São Paulo, 2014. 143 p.

A presente dissertação objetiva analisar o debate acerca da ratificação do Tratado de Comércio entre Brasil e EUA, em 1935. Observamos, na historiografia acerca do episódio, que os grupos em disputa foram designados como os "representantes da indústria" (contrários ao tratado) versus os da "agroexportação", (favoráveis ao tratado). Contudo, foi possível verificar, a partir da análise da documentação, que quase nenhuma das manifestações em defesa do tratado foi encaminhada por representantes diretos das frações de classe ligadas às atividades agroexportadoras, sejam os deputados classistas representantes da Lavoura, ou as associações de classe ligadas a ela. Assim, buscamos averiguar a conformação concreta de tais grupos. Propusemos, então, a hipótese de que os defensores do tratado fariam parte de uma elite formada e educada em um período de hegemonia do pensamento liberal, segundo o qual o caráter da economia brasileira seria essencialmente agrário e a indústria ocuparia papel secundário. Concluímos que a defesa do tratado foi feita por membros da burocracia estatal e da elite política, em nome de uma ideologia particular, afinada em vários aspectos com os interesses das elites agrárias, mas não diretamente motivada pela defesa destes, tendo ainda como elemento central considerações de cunho geopolítico e estratégico. Uma lógica própria, ligada aos interesses da própria burocracia estatal, teria sido a matriz ideológica que norteou sua ação política. Finalmente, interpretamos a atuação das lideranças industriais na defesa do Tratado, como um momento importante no processo de constituição dessa fração de classe e como ator político autoconsciente na construção de um consenso em torno de um projeto nacional fundamentado na industrialização, como via de desenvolvimento nacional.

Palavras-chave: Governo Vargas, política externa, grupos de interesse, ideias econômicas, hegemonia. 


\begin{abstract}
Danilo Barolo Martins de LIMA. The debate about the Commercial Treaty between Brazil and the United States (1935): Class, state and projects for Brazil. University of São Paulo, Faculdade de Filosofia, Letras e Ciências Humanas. São Paulo, 2014. 143 p.
\end{abstract}

This dissertation aims to analyze the debate over the parliamentary ratification of the Treaty of Trade between Brazil and USA, in 1935. We have observed in the historiography that addresses the episode, that the disputing groups were designated as the "industry representatives" (contrary to the treaty) versus the "agro-export" supporters (favorable to the treaty). However, we have been able to find, by way of the analysis of the documents concerning such debate, that almost none of the statements in defense of the Treaty was given by direct representatives of the class fractions linked to agro-export activities, such as the class members of the National Congress, representing agricultural interests, or associations connected to it. Thus, we sought to determine the specific conformation of such groups. Therefore we proposed the hypothesis that the proponents of the Treaty would be part of an elite, trained and educated in a period of hegemony of liberal thinking, whereby the character of the Brazilian economy and the industry would be represented as essentially agrarian and industry occupied a secondary role. We concluded that the defense Treaty was made mainly by members of the state bureaucracy and the political elite, on behalf of a particular ideology tuned in several respects with the interests of the agrarian elites, but not directly motivated by their promotion, having also as a central element geopolitical considerations of strategic nature. Its own logic, linked to the interests of the state bureaucracy itself, would have been the ideological matrix that guided their political action. Finally, we interpret the role of industrial leaders in upholding the Treaty as an important moment in the constitution of this class fraction as a self-conscious political actor in building a consensus around a national project, based on industrialization as a means for national development.

Keywords: Vargas Government, foreign policy, interest groups, economic ideas, hegemony. 


\section{LISTA DE FIGURAS E GRÁFICOS}

Figura 2.1 - Valores totais de importação de mercadorias pelo Brasil,

procedentes dos EUA, Alemanha e Grã-Bretanha, no período 1928-1939.

Figura 2.2. - Valores totais de exportação de mercadorias do Brasil,

destinadas aos EUA, Alemanha e Grã-Bretanha, no período 1928-1939.

Figura 4.1 - Recorte ("Clipping") feito por diplomatas brasileiros, residentes

em Washington, contendo reportagem no jornal norte-americano The New

York Times....

Figura 5.1 - Fotografia: A assinatura do Tratado de Comércio entre Brasil e Estados Unidos

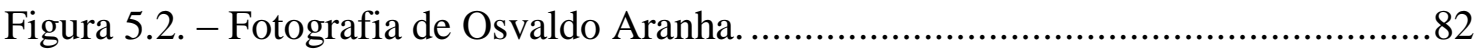

Figura 6.1. Exemplo de ata de reunião do CFCE. ..................................................91

Figura 7.1. Exemplo de páginas das atas de sessões parlamentares. ...........................92

Figura 7.2. - Fotografia de Roberto Simonsen.......................................................... 123

Figura 8.1. - Valores estimados totais da produção industrial - para o Brasil e para o estado de São Paulo (1919-1938). 


\section{LISTA DE ABREVIATURAS E DE SIGLAS DE DOCUMENTOS}

ACSP

ARQUIVO OA

ARQUIVO GV

ARQUIVO ITAMARATY Arquivo Histórico do MRE

CFCE

FIESP

GV

MRE

OA

SRB

Sociedade Rural Brasileira
Associação Comercial do estado de São Paulo

Arquivo pessoal de Osvaldo Aranha (CPDOC-FGV, RJ)

Arquivo pessoal de Getúlio Vargas (CPDOC-FGV, RJ)

Conselho Federal do Comércio Exterior

Federação das Indústrias do Estado de São Paulo

Getúlio Dornelles Vargas (Presidente da República)

Ministério das Relações Exteriores

Osvaldo Euclides de Sousa Aranha (embaixador nos EUA) 


\section{SUMÁRIO}

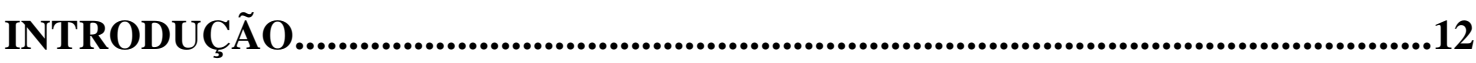

Capítulo 1 - Referenciais Teóricos, Metodologia e Fontes......................................16

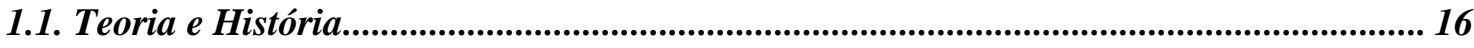

1.2. Definições: Conceitos e Categorias .................................................................................. 19

1.3. Um quadro mais geral - A Economia Mundial: Ciclos e hegemonias históricas............. 35

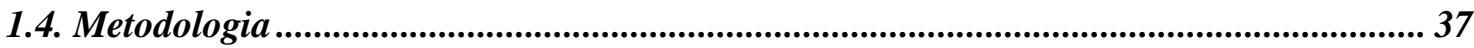

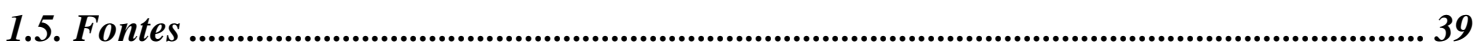

Capítulo 2 - As questões gerais da Historiografia .................................................41

2.1. Economia e Política: O Estado brasileiro e a industrialização na década de 1930......... 41

2.2. Sociedade: Classes e Frações de classe no Brasil da década de 1930.............................. 45

2.3. As Ideias - pensamento econômico e político ......................................................................... 48

Capítulo 3 - O Tratado Brasil-EUA de 1935: História e Historiografia...................56

3.1. História - O Tratado no contexto: Crise e oportunidades......................................................56

3.2. O Tratado e a Historiografia: Indústria versus agroexportação? ...................................... 60

Capítulo 4 - Problemas e Hipóteses de Trabalho .................................................69

Capítulo 5 - A Negociação do Tratado ....................................................................73

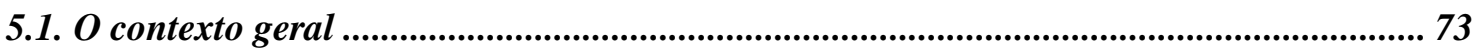

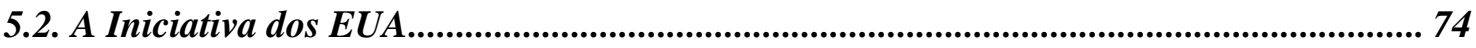

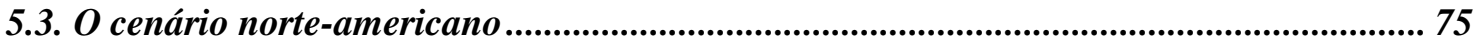

5.4. O governo dos EUA pressiona o Brasil ................................................................................... 77

5.5. A atuação de Osvaldo Aranha e a assinatura do Tratado ................................................... 78

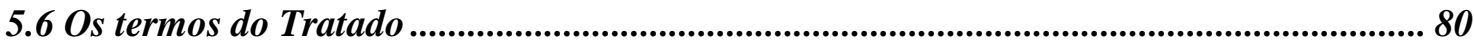

5.7. O que se seguiu: os debates acerca da ratificação e seu desfecho final............................. 80

Capítulo 6 - O Debate no Âmbito do Governo Federal ......................................83

6.1. As discussões no Conselho Federal de Comércio Exterior ............................................ 83

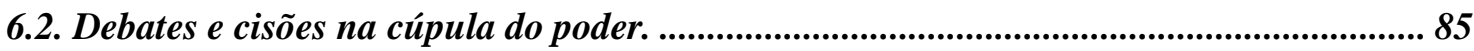


Capítulo 7 - O Debate na Câmara dos Deputados .................................................92

7.1. Definições: Como entender a conformação dos grupos no debate? ................................. 93

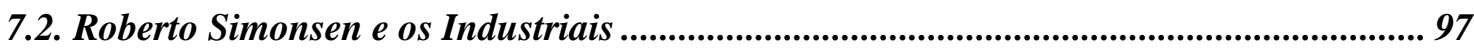

7.3. Octávio Mangabeira e a Oposição Parlamentar ...................................................................... 110

7.4. Paulo Martins e a Burocracia Estatal .................................................................................. 113

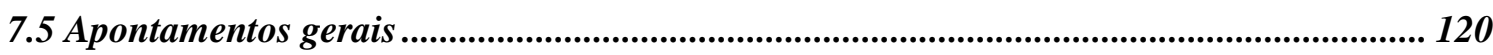

Capítulo 8 - O Debate nas Associações de Classe e na Imprensa ..........................124

8.1. As associações de classe e o Tratado: $O$ silêncio da Agricultura e a

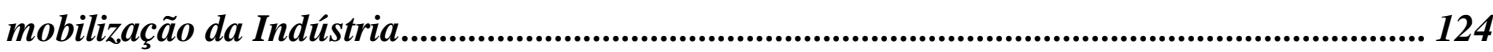

8.2 A Associação Comercial de São Paulo e a representatividade da posição de

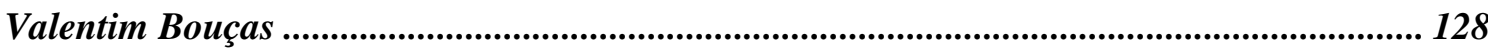

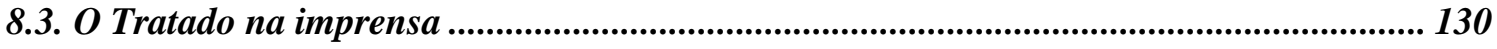

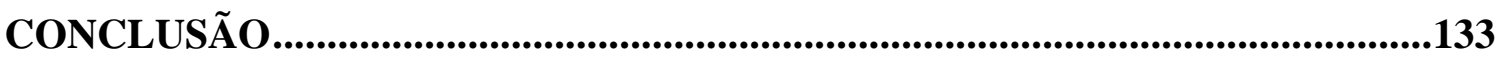

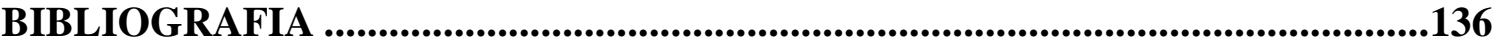




\section{INTRODUÇÃO}

O Tratado de Comércio entre o Brasil e os Estados Unidos, assinado em Washington, em dois de fevereiro de 1935, foi um acordo comercial, que visava à liberalização do comércio em um contexto de crise e crescente protecionismo. Foi um entre mais de trinta tratados semelhantes, celebrados pelo Brasil, entre 1930 e 1935, sendo, porém, o mais importante. Além da evidente importância econômica que comportava, uma vez que os EUA eram então o maior mercado consumidor das exportações brasileiras e o maior fornecedor de importados, sua relevância deve ser avaliada pela gravidade da conjuntura histórica na qual se inscreveu.

Contudo, quanto ao objeto do presente estudo, acredito ser necessário um breve esclarecimento: não se trata de um estudo acerca do Tratado de 1935 per se. Trata-se, na verdade, de um estudo acerca do debate que se precedeu à sua assinatura e sua ratificação parlamentar, nos diversos âmbitos e espaços nos quais se desenrolou.

Tal debate teve como palco as sessões plenárias da Câmara dos Deputados, algumas das associações de classe vinculadas à produção agrícola, comércio e indústria, o interior da estrutura do governo federal e seus conselhos técnicos, os ministérios da Fazenda, e das Relações Exteriores, bem como a embaixada do Brasil em Washington e a imprensa nacional; em todas as instâncias em que o debate foi travado, este mobilizou grupos de interesse e articulou ideias econômicas, políticas e concepções acerca da natureza e do futuro almejado para o país.

Quanto à relevância da escolha de tal objeto para uma pesquisa no campo da História Econômica do Brasil, esperamos ao longo do trabalho ter evidenciado que o referido episódio pôde nos fornecer um ponto de vista interessante para a compreensão do período histórico no qual se insere. Período este que pode ser delimitado tanto por referenciais mundiais, como o da era da grande crise econômica, deflagrada com o crash de 1929 e suas reconfigurações geopolíticas e transições de hegemonia, quanto por caracteres mais especificamente brasileiros.

Estes últimos podem ser tanto referenciais de caráter mais político quanto de referenciais mais próprios da História Econômica e Social. Os referenciais políticos delimitam o período do chamado Primeiro Governo Vargas (1930-1945), com seus movimentos de construção de um Estado centralizado, burocratizado e mais atuante na 
esfera econômica, mas também por suas oscilações entre a dependência e o alinhamento com os EUA, e uma aproximação comercial e política com a Alemanha. Já as balizas econômicas e sociais marcam um período decisivo para o processo de industrialização do Brasil, bem como para a formação de uma elite industrial nacional, cada vez mais consciente de si mesma como ator político.

Dependendo do ponto de vista que se assume, poder-se-ia afirmar que o debate configura um evento cuja temporalidade particular mais imediata pode ser inscrita numa "curta duração" - o tempo da política, dos fatos fugazes e da tradicional história événementielle, segundo a proposição de Fernand Braudel. Delimitar-se-ia, assim, tal período entre o início efetivo das negociações para a assinatura do Tratado, no início do ano de 1933, até o fim de seu processo de ratificação, culminando com a sua aprovação e sanção presidencial, em dezembro de 1935. Contudo, a apreensão da temporalidade do objeto estudado, apenas a partir da perspectiva do "tempo curto", não esgota as possibilidades interpretativas à disposição do pesquisador.

Acreditamos que este pode ser analisado como um momento singular, que de certa maneira nos permitiria observar algo como uma "síntese" de alguns dos problemas e processos históricos mais importantes desse período da história brasileira. Permitir-nosia, portanto, observar um dos "nós" que ligam processos de longa duração, tais como o da formação do capitalismo e da sociedade industrial no Brasil, com sua particular composição social e política.

Há certo consenso na historiografia acerca do Tratado, ${ }^{1}$ indicando que, apesar dos esforços dos norte-americanos, das tensões e oposições acaloradas em solo brasileiro e dos temores de seus opositores industrialistas, os efeitos concretos da vigência efetiva do Tratado não foram de grande monta. A exportação de café não se alterou significativamente, nem as importações de produtos manufaturados estadunidenses se elevaram em decorrência direta do Tratado. Assim, o Tratado per se talvez não possa ser considerado tão relevante para a história econômica do Brasil.

Porém, uma análise dos documentos produzidos no debate enfocado, principalmente no âmbito parlamentar, mas também no Conselho Federal de Comércio Exterior, nas associações de classe e no governo, pode ser muito interessante para o estudo dos grupos que então se conformaram, bem como das ideias e ideologias que orientavam os projetos para o futuro da inserção do país na economia mundial.

\footnotetext{
${ }^{1}$ Ver Capítulo 2 da presente Dissertação.
} 
O Tratado de 1935, ou os debates que o cercaram, nunca foram objetos de um estudo histórico específico mais amplo, ${ }^{2}$ seja na forma de livro, ou tese acadêmica. Há, contudo, uma série de obras, oriundas dos campos da História ou da Ciência Política, as quais utilizaram este evento apenas como um episódio ilustrativo para a análise de algum outro conjunto de questões, tais como a constituição do empresariado industrial como classe politicamente atuante, ${ }^{3}$ ou como ferramenta para a análise da política externa brasileira no período, ${ }^{4}$ por exemplo.

Tais análises partem de abordagens diversas, tanto em termos das perspectivas teóricas escolhidas, problemas colocados e seus objetivos mais gerais, quanto em relação ao nível de atenção dedicada ao Tratado. Contudo, observa-se como traços gerais que alguns trabalhos enfatizam o aspecto geopolítico ${ }^{5}$, enquanto outros procuram enfocar os conflitos que envolveram classes, ou grupos de interesse, porém priorizam apenas um dos lados da disputa, o dos industriais, opositores do Tratado. ${ }^{6}$ Além disso, comumente, o mapeamento dos grupos em disputa tende a assinalar o conflito entre o interesse da indústria e o da chamada "agroexportação". 7 Como será proposto na presente dissertação, tal caracterização deve ser reavaliada frente à evidência documental.

Algumas questões, então, surgiram, a partir do confronto destas interpretações, presentes nas análises da historiografia acerca do Tratado, com os documentos analisados: Qual teria sido concretamente a conformação dos grupos que se confrontaram no debate, particularmente o dos defensores do tratado? Os participantes do debate acerca do Tratado podem ser considerados representantes diretos de classes ou frações de classe específicas? É possível identificar o caráter de algumas das ideias defendidas?

O objetivo da presente dissertação foi a análise deste debate, a fim de sugerir possíveis respostas para essas e outras questões. A partir da análise documental realizada, constatamos que quase não houve a participação direta de representantes classistas da lavoura e pecuária no referido debate. Ao invés disso, os defensores mais ativos do Tratado eram membros da burocracia estatal e da elite política. Além disso, a partir da análise do teor dos discursos dos defensores do Tratado e também de seus opositores,

\footnotetext{
${ }^{2}$ Há, porém, um artigo publicado em periódico dedicado à análise do Tratado. Ver D'ARAÚJO e MOURA, 1978.

${ }^{3}$ Ver DINIZ, 1978.

${ }^{4}$ Ver MOURA, 1980.

${ }^{5}$ Ver GAMBINI, 1977, HILTON, 1977, MOURA, 1980 e ABREU, 1999, por exemplo.

${ }^{6}$ Ver D’ARAÚJO e MOURA, 1978, LEME, 1976 e DINIZ, 1978.

${ }^{7}$ Cf. DINIZ, 1978, GAMBINI, 1977, LEME, 1976, por exemplo. Para uma discussão mais aprofundada das questões relativas às análises do Tratado na Historiografia, ver o Capítulo 3 da presente dissertação.
} 
pudemos identificar algumas das ideias políticas e econômicas centrais, que orientavam suas proposições.

Ao final, propusemos uma interpretação alternativa para qualificar as visões tradicionais: a defesa do tratado foi feita por membros da burocracia estatal e da elite política, em nome de uma ideologia particular, afinada em vários aspectos com os interesses das elites agrárias, mas não diretamente motivada pela defesa destes. Uma lógica própria, ligada aos interesses de alinhamentos estratégicos de Vargas e da Cúpula do Estado, bem como os interesses próprios da burocracia estatal, seria a matriz ideológica que orientou sua ação política.

Procuramos, finalmente, construir uma interpretação acerca do ataque ao Tratado, levado adiante pela oposição industrial, como uma etapa num processo de constituição desta fração de classe como ator político e, concomitantemente, de uma disputa pela hegemonia no bloco de frações de classe que dirigem o Estado, processo este que passou necessariamente pela elaboração de projetos diferenciados para o Brasil e de um consenso em torno da necessidade da industrialização para o desenvolvimento nacional.

A presente dissertação foi organizada em oito capítulos, além da introdução e da conclusão. No primeiro capítulo, expusemos nossas escolhas quanto aos referenciais teóricos, metodologia e fontes, que fundamentaram a pesquisa. Nos dois capítulos seguintes, apresentamos uma discussão acerca das questões e debates mais relevantes na historiografia econômica, política e social do Brasil no período, bem como as análises acerca do Tratado de 1935. No quarto capítulo, definimos os problemas e hipóteses que abordamos em nossa análise. Em seguida, empreendemos a análise das fontes em cada um dos âmbitos acima mencionados, desde o momento das negociações prévias à assinatura do Tratado, até sua ratificação parlamentar. Ao final, tecemos algumas considerações finais acerca dos significados históricos que pudemos extrair dos eventos estudados. 


\section{Capítulo 1 - Referenciais Teóricos, Metodologia e Fontes}

\subsection{Teoria e História}

Uma teoria pode ser concebida, segundo Barros, numa primeira acepção mais geral, como uma representação racional sobre o real, numa tentativa de compreendê-lo e/ou explicá-lo. ${ }^{8}$ Evidencia-se aqui a relação intrínseca e dialética existente entre a teoria, de um lado, e a coleta, sistematização e análise de dados empíricos, de outro. E tal relação se constitui um dos fundamentos de qualquer campo do conhecimento científico atual.

Assim, acreditamos que um trabalho de pesquisa em História parte de certas preocupações relacionadas a questões teóricas, pertinentes ao seu campo e próprias do seu tempo (tais como os modelos interpretativos elaborados para explicar certos fenômenos históricos) e dos debates travados em torno delas, na busca de contribuir para uma compreensão empírica da realidade. Exemplos clássicos, no campo da História Econômica do Brasil são os debates em torno do caráter da vinculação da América Portuguesa aos centros econômicos europeus, ou acerca da caracterização da organização da produção no período colonial. ${ }^{9}$

Contudo, ao mesmo tempo em que a teoria permite "enxergar" a realidade de uma forma específica e fornece um conjunto particular de questões (e de respostas possíveis para estas questões), bem como indica métodos para o trabalho com as fontes; também a investigação empírica é necessária para validar e repensar as formulações teóricas. O caminho para a teorização pode se dar a partir de constatações empíricas, que embasam enunciados de maior alcance, os quais, por sua vez devem ser colocados "à prova" através de observações acerca de fenômenos aparentemente análogos ou semelhantes.

A História Econômica pode ser entendida como um campo de especialização da História, o qual se define por seu enfoque, ao privilegiar um aspecto, "dimensão", ou esfera da existência social dos homens: a "economia", ou seja, os fatos relativos à produção, a circulação, o consumo e a apropriação dos produtos do trabalho humano. Tal

\footnotetext{
${ }^{8}$ BARROS, José D’Assunção. Teoria da História. vol. 1: Princípios e conceitos fundamentais. Petrópolis: Vozes, 2011, p. 50-52.

${ }^{9}$ Cf. NOVAIS, F. Portugal e Brasil na crise do antigo sistema colonial. São Paulo: Hucitec, 1985; FRAGOSO J. e FLORENTINO, M. O Arcaísmo como Projeto.. Rio de Janeiro: Diadorim, 1993 e F GORENDER, J. $O$ Escravismo Colonial. São Paulo: Ática, 1980, entre outros.
} 
enfoque se justifica na medida em que permite um tratamento mais preciso do objeto e se fundamenta em um acúmulo de conhecimento, teórico e empírico, produzido por especialistas do campo, um conjunto de referenciais conceituais próprios, etc. ${ }^{10}$

Contudo, acreditamos que as explicações possíveis para fenômenos tidos como "essencialmente econômicos", podem muitas vezes se localizar na inter-relação de elementos diversos - tais como aspectos geográficos, demográficos, relações políticas, ideias, representações e elementos culturais. Assim, acreditamos que o estudo de discursos, de ideias (econômicas, políticas e quaisquer outras relacionadas), bem como de uma "economia política", situada historicamente, são objetos legitimamente pertinentes ao campo da História Econômica.

Portanto, ao nos situarmos no interior desse campo, procuramos nos apropriar de referenciais teóricos, conceituais e de modelos interpretativos, sejam aqueles próprios da História Econômica, ou aqueles provenientes de outras especialidades da História - as chamadas Histórias "Social", "Cultural", "Política", "das ideias", etc. -, bem como de outros campos disciplinares, tais como a ciência política, a economia e a sociologia.

Finalmente, o contraste com a investigação empírica pode, inclusive, "por a prova" a validade de tais referenciais teóricos e conceituais para orientar uma apreensão mais adequada dos fenômenos históricos estudados. Afinal, os fatos em geral não se “encaixam” perfeitamente nos modelos teóricos mobilizados para explica-los.

Contudo não se deve esquecer que tais modelos, desde que historicamente formulados e constantemente revisados, podem ser úteis para situar os fatos num quadro mais amplo do conhecimento, bem como para perceber mais claramente as relações entre aspectos da realidade que, de outra forma, pareceriam fragmentados, confusos, ou incompreensíveis da maneira em que aparecem imediatamente aos observadores.

É possível discernir no campo da Teoria da História um conjunto de grandes correntes teóricas, pautadas em fundamentos epistemológicos próprios. Tais correntes são aqui denominados pela noção de paradigmas historiográficos. ${ }^{11}$ No presente trabalho, entre os referenciais teóricos, figuram em destaque alguns autores pertencentes ao paradigma do materialismo histórico, tais como Antonio Gramsci, Edward Thompson, entre outros. Contudo, não assumimos aqui uma filiação exclusiva a este paradigma e

\footnotetext{
${ }^{10}$ A definição segue em linhas gerais o proposto por NOVAIS, Fernando A. e FORASTIERI, Rogério (org. e introdução). Nova História em perspectiva. V. 1. São Paulo: Cosac Naify, 2011, p. 7-70.

${ }^{11}$ Tal noção é apresentada por BARROS, 2011, op. cit.
} 
buscamos incorporar, sempre que foi considerado profícuo para as finalidades da pesquisa, aportes de outras correntes. Entre tais aportes conceituais, destacamos a noção de "economia-mundo" e, obtida a partir das obras de Giovanni Arrighi e Fernand Braudel, associados direta ou indiretamente à Escola dos Annales. ${ }^{12}$

É digno de nota que, quando nos apropriamos de tais referenciais, procuramos sempre nos distanciar de visões deterministas, bem como de formas reducionistas de se conceber as relações entre as diversas "esferas da existência social" (a economia, a política, a cultura, etc.). Colocando a questão de outra maneira, de acordo com o vocabulário próprio do marxismo, trata-se de rejeitar a ideia de uma determinação direta e "mecânica" de uma esfera sobre a outra. Trata-se de buscar apreender as complexas relações recíprocas entre as "esferas" e como estas relações podem fornecer um quadro explicativo mais amplo para os fenômenos estudados. Dessa maneira, concordamos integralmente com a asserção feita por Carlos Nelson Coutinho:

Ao contrário do que pensa certo marxismo economicista ou vulgar, o modo pelo qual economia e política se relacionam não é dado de uma vez por todas: o modo de articulação entre as duas esferas, o maior ou menor poder de determinação em sua ação recíproca, dependem do tipo específico da formação social em questão, sendo, portanto, um fenômeno historicamente mutável. ${ }^{13}$

Nesse mesmo sentido, concordamos também com a proposição de Ellen $\mathrm{M}$. Wood, segundo a qual é preciso superar a falsa dicotomia entre economia e política, reconhecendo o que há de econômico na política e o que há de político nas relações "econômicas", chegando a pensar tanto o Estado, quanto as estruturas produtivas como relações sociais, historicamente determinadas. ${ }^{14}$

\footnotetext{
${ }^{12}$ Resta notar que, de acordo com Ciro F. Cardoso, tanto os Annales (em suas duas primeiras gerações), quanto o Materialismo Histórico partem de uma mesma matriz paradigmática, denominada "iluminista" e, portanto, segundo este autor, os diálogos entre eles, mais do que possíveis, foram amplos e constantes na historiografia do século XX. Cf. CARDOSO, Ciro Flamarion. História e paradigmas rivais. In: VAINFAS, Ronaldo e CARDOSO, Ciro Flamarion (orgs.). Domínios da história. SP: Campus, 2011, pp. 1-22.

13 COUTINHO, Carlos Nelson. Gramsci: um estudo sobre seu pensamento político. Rio de Janeiro: Civilização Brasileira, 2007, p. 100.

${ }^{14}$ WOOD, Ellen Meiksins. Democracia contra capitalismo: a renovação do materialismo histórico. São Paulo: Boitempo, 2003, p. 27-72.
} 


\subsection{Definições: Conceitos e Categorias}

\subsubsection{Estado e Estado Capitalista}

Um dos pontos focais da análise empreendida no presente trabalho é a apreensão de algumas das características definidoras do Estado brasileiro na década de 1930 e de qual teria sido o seu papel, com relação às questões pertinentes à política econômica e internacional. Mais especificamente, nos interessa o papel desempenhado por supostos representantes de classes, ou frações de classe, e por membros da burocracia estatal no debate sobre o Tratado Brasil-Estados Unidos, de 1935. Dessa forma, acreditamos que cabem inicialmente algumas definições quanto às nossas concepções acerca do Estado.

Há várias maneiras de se conceber teoricamente o fenômeno do Estado. Desde a visão dos clássicos da filosofia política, que pensaram o Estado como uma forma de autoridade instituída por uma espécie de "contrato social” entre indivíduos livres, a fim de preservar sua integridade e/ou suas liberdades, ${ }^{15}$ passando pela definição liberal do Estado como conjunto de instituições destinadas a servir ao "bem comum", ou ao "interesse nacional", ${ }^{16}$ assim como pela celebre formulação weberiana do Estado como um aparato administrativo e político que detém o monopólio da violência legítima dentro de um determinado território, ${ }^{17}$ até as diversas concepções liberais contemporâneas. ${ }^{18}$

No interior do paradigma teórico do materialismo histórico, também diversas foram as visões elaboradas acerca do Estado. Segundo Bob Jessop, o elemento comum a todas essas concepções associadas ao materialismo histórico é a vinculação do Estado à existência das classes sociais e de relações assimétricas de poder entre elas. ${ }^{19}$ Seriam as lutas históricas entre tais classes que constituiriam a própria estrutura social e, portanto, também a estrutura do próprio Estado. O fundamental é que deve haver uma relação, mais ou menos direta, entre o Estado e a organização da produção. Ou seja, para os autores marxistas, o Estado não pode ser pensado como uma "esfera" separada, neutra, situada "acima" da sociedade civil, ou como um conjunto de instituições completamente autônomo em relação aos interesses de grupos e classes econômicas.

\footnotetext{
${ }^{15}$ Cf. WEFFORT, Francisco C. (Org.). Os clássicos da política. v1. São Paulo: Ática, 2010.

${ }^{16}$ CARNOY, Martin. Estado e teoria política. 16a ed. Campinas: Papirus, 2011, p. 19-50.

${ }^{17}$ WEBER, Max. Ciência e Política: Duas vocações. São Paulo: Martin Claret, 2005.

${ }^{18}$ CARNOY, op. cit., p. 50-62.

19 JESSOP, Bob. Putting the capitalist state in its place. Oxford: Blackwell Publishing, 1990, p. 27-8.
} 
Ao contrário, o problema do Estado, bem como as suas diferentes concepções teóricas no seio do materialismo histórico, se definiu precisamente quanto às diferentes compreensões acerca do caráter das relações entre o fenômeno estatal e as classes que constituem uma dada sociedade, especialmente quanto à forma do poder que sobre ele exercem as classes dominantes. No presente estudo, procuramos nos afastar das concepções mais simplistas, que tendem a ver o Estado como mero instrumento dos interesses de uma classe dominante homogênea, que o controlaria de forma direta. Vale dizer que o próprio Marx tratou de desenvolver uma visão muito mais nuançada e complexa dessa relação, tal como se pode depreender de suas obras de análise política, como no Dezoito de Brumário. ${ }^{20}$

Para o paradigma do materialismo histórico, o Estado não pode ser corretamente definido como Estado "em geral", abstrato, tendo-se que considerar as relações concretas de poder entre as classes em um dado contexto histórico. Se, na contemporaneidade, há o domínio das classes capitalistas, o Estado deve ser um "Estado capitalista". Porém, isso não quer dizer que as relações entre as classes dominantes e o Estado sejam assim tão simples. Numa análise histórica, se verifica o fato de que há diversas instâncias nas quais essas relações foram complexas, contraditórias, e por vezes conflitivas. Tal é o caso de sociedades que passam por processos de modernização, nos quais a classe politicamente dirigente não é a mesma que comanda as transformações econômicas.

No presente trabalho, nos aproximamos da perspectiva de Antonio Gramsci, segundo a qual o Estado tem um papel vital para unificar e organizar as classes dominantes em seu domínio político e ideológico. Na obra deste marxista italiano, o Estado não é apenas o lócus por excelência do domínio pela força. O Estado passa a ser visto como tendo simultaneamente o papel de promover uma forma de "liderança" pelo consenso. ${ }^{21}$ Gramsci desenvolveu um enfoque marxista alternativo e "ampliado" do Estado, definindo-o como: "Todo complexo de atividades práticas e teóricas com o qual a classe dominante não somente justifica e mantém seu domínio, mas procura conquistar o consentimento daqueles sobre os quais exerce sua dominação".22

O Estado, na forma "ampliada", portanto, seria visto por Gramsci como constituído de duas esferas, a sociedade civil, isto é, um conjunto das organizações - os

\footnotetext{
${ }^{20}$ MARX, Karl. O 18 de Brumário de Luís Bonaparte. Trad. Nélio Schneider. São Paulo: Boitempo, 2011.

${ }^{21}$ COUTINHO, op. cit., p. 42.

${ }^{22}$ GRAMSCI, Antonio. Cadernos do cárcere. Tradução e edição de Carlos Nelson Coutinho. v. 3 Rio de Janeiro: Civilização Brasileira, 2003.
} 
"aparelhos privados de hegemonia"23 -, responsáveis pela elaboração e/ou difusão de ideologias, (sistema escolar, as igrejas, os partidos políticos, as organizações profissionais, mídia, etc.); e o Estado, em sentido estrito, ou "sociedade política", a qual seria equivalente ao "aparelho de coerção que assegura legalmente a disciplina dos grupos que não consentem, nem ativa nem passivamente, mas que é constituído para toda a sociedade, na previsão dos momentos de crise no comando e na direção, quando fracassa o consenso espontâneo". ${ }^{24}$

A complexa combinação de consenso e coerção, determinante da supremacia de uma classe, é bem ilustrada pela conhecida afirmação de Gramsci:

A supremacia de um grupo social se manifesta de duas maneiras, como 'domínio' e como 'direção intelectual e moral'. Um grupo social é dominante dos grupos adversários, que tende a 'liquidar' ou submeter mesmo que com a força armada e é dirigente dos grupos afins ou aliados. Um grupo social pode e deve ser dirigente já antes de conquistar o poder governativo (esta é uma das condições principais para a própria conquista do poder); depois, quando exercita o poder e na medida em que o mantém fortemente em suas mãos, torna-se dominante, mas deve continuar sendo dirigente. $^{25}$

O Estado aparece para Gramsci, portanto, não somente como mero instrumento de domínio de classe pela coerção, mas também como instância fundamental da constituição do arcabouço ideológico de uma sociedade. Ele atribuiu ao Estado parte da função de promover um conceito universal de realidade, a ser incorporado e aceito pela maioria, consistindo em elemento central na construção da hegemonia e fornecendo uma das bases fundamentais do poder de classe, ao menos nas sociedades de tipo "ocidental" ${ }^{26}$

Também, a partir da obra de Nicos Poulantzas, obtivemos algumas referencias interessantes para a compreensão do Estado capitalista, ainda que não adiramos

\footnotetext{
${ }^{23}$ Coutinho e Secco contrastam este conceito ao de "aparelhos ideológicos de Estado" de L. Althusser, cujo problema seria o de não enfatizar o grau de autonomia relativa desses aparelhos em relação ao Estado. Cf. COUTINHO, op. cit., p. 133 e SECCO, Lincoln. Gramsci e a Revolução. São Paulo: Alameda, 2006, p. 198-200.

${ }^{24}$ COUTINHO, op. cit., p. 127-130.

${ }^{25}$ GRAMSCl, op. cit., p. 130.

${ }^{26}$ É bastante conhecida a distinção traçada por Gramsci entre as sociedades por ele denominadas "orientais", conjunto de nações onde o Estado é muito forte em sua capacidade coercitiva e a sociedade civil é frágil e pouco desenvolvida, e as "ocidentais", onde a sociedade civil é complexa e seus aparelhos de hegemonia servem como "trincheiras" que atuam para manter o poder da burguesia, quando este é ameaçado. Numa sociedade ocidental, a mera tomada do Estado, não seria, portanto, suficientemente eficaz para se concretizar uma revolução social, sendo necessário o gradual processo de construção da hegemonia, o qual Gramsci denominou "guerra de posição". Cf. SECCO, op. cit., p. 197.
} 
integralmente à concepção teórica deste autor. Interessa-nos, sobretudo, a noção de "bloco no poder", a qual pode ser definida como:

Um bloco de forças e classes dominantes, independente de um acordo político explícito, cuja unidade, em torno de objetivos políticos gerais, é garantida pelo aparelho do Estado. Tende a formar-se um núcleo hegemônico, uma fração ou um conjunto de frações de classe que faz prevalecer seus interesses no bloco, o que se traduz na capacidade de obter prioritariamente os benefícios da política econômica e social. Os fatores dessa hegemonia podem ser o poder econômico, a capacidade de organização político-ideológica e de pressão sobre o Estado. ${ }^{27}$

Esta nos parece uma noção interessante para a compreensão das relações entre as classes dominantes (e distintas frações destas), o Estado e as classes subordinadas.

Bob Jessop, por sua vez, apresentou uma interessante contribuição, ao insistir na tese de que o Estado deve ser visto sempre e antes de tudo como um conjunto de relações sociais. Trata-se de vê-lo como um complexo institucional, cujas orientações políticas são disputadas ativa e continuamente por forças políticas em conflito, através de estratégias diferenciadas. A eficácia de tais estratégias é, contudo, "seletiva", o que significa que as lutas pelo poder do Estado - e pela própria constituição do Estado -, são travadas a partir de posições prévias de poder assimétricas, mas que só se configuram historicamente. Assim, é possível evitar uma dicotomia entre "sujeito e estrutura", em favor de uma concepção dialética, uma vez que é a ação dos sujeitos, através das estratégias que empregam, que vai moldar os contextos seletivos, no interior dos quais certas estratégias se mostram sucessivamente mais bem sucedidas do que outras. ${ }^{28}$

\subsubsection{Classes e frações de classe}

A fim de que possamos empreender a análise dos grupos envolvidos no debate acerca da ratificação do Tratado de Comércio Brasil-Estados Unidos, de 1935, pensamos que é preciso definir claramente quais as categorias analíticas que acreditamos serem as mais eficazes para apreender e explicar a atuação de tais grupos frente ao episódio.

\footnotetext{
27 Cf. POULANTZAS, Nicos. O Estado, o poder, o socialismo. Rio de Janeiro: Graal, 1985; Idem. Poder político e classes sociais. São Paulo, ed. Martins Fontes, 1977. A definição é enriquecida pelas considerações de FARIAS, Francisco P. de. Frações burguesas e bloco no poder: uma reflexão a partir do trabalho de Nicos Poulantzas. In: Crítica Marxista, n. 28, 2009. p. 93.

${ }^{28}$ JESSOP, op. cit., p. 338-369.
} 
Algumas hipóteses iniciais se apresentam: Seria o conceito de classe o mais adequado para descrever os grupos que se conformaram naquele momento? $\mathrm{Ou}$, de outra forma, seriam tais grupos melhor definidos em termos de recortes de classe? E, sendo este o caso, seriam cada uma das posições opostas, contra e a favor da aprovação do tratado, definidas em termos de interesses de classe distintos?

Primeiramente, cabe definir o que entendemos pelo conceito de classe. Há várias vertentes na teoria social que utilizam esse conceito, com significados divergentes, tais como a Weberiana, por exemplo. A classe pode ser concebida, numa primeira aproximação, como um agrupamento de indivíduos, que partilham de uma situação comum no interior de uma sociedade. Partiremos aqui de uma concepção cara ao materialismo histórico, segundo a qual trata-se de definir tal posição a partir inicialmente de sua inserção no interior das relações sociais de produção. ${ }^{29}$

Porém, a situação "econômica" de classe não esgota o conceito. Resta a questão de se pensar a classe como sujeito coletivo, o que é fundamental para a teoria social. Para isso, seria preciso abordar a questão da consciência de classe: até que ponto as condições econômicas de um dado grupo, no interior da esfera produtiva, se relacionam com essa consciência? ${ }^{30}$

Um amplo debate se deu entre os seguidores de Marx, acerca de qual seria a definição mais correta, em termos teóricos e epistemológicos, para o conceito de classe. Algumas posições tendem a reforçar o aspecto das determinações "objetivas" de classe (a unidade contraditória de relações de produção e forças produtivas), em detrimento da consciência. Outros o fizeram na direção oposta, dando primazia à consciência, de forma que, para estes últimos, uma classe só existe plenamente na medida em que se constituir em sujeito político consciente.

Não podemos aqui nos aprofundar nesse debate, mas pensamos que Edward P. Thompson apresenta uma concepção de classe que pode permitir a superação dessa dicotomia. Este historiador inglês considera as classes como realidades históricas dinâmicas, em processo, e cuja existência concreta se relaciona simultaneamente com sua

\footnotetext{
${ }^{29}$ SILVA, Kalina V. e SILVA, Maciel H. Dicionário de conceitos históricos. 2a ed. São Paulo: Contexto, 2006, p. 63-66.

${ }^{30}$ BOTTOMORE, Tom. (ed.) Dicionário do pensamento marxista. Rio de Janeiro: Jorge Zahar ed., 2001, p. 61-63.
} 
materialidade e consciência. ${ }^{31}$ Thompson se posiciona contra correntes que tendem a ver a classe como algo "estático", que pode ser definido estruturalmente. ${ }^{32}$

Para Thompson, também não se trata de uma realidade "subjetiva" apenas, sendo uma realidade histórica que se efetiva na mediação entre as determinações das relações produtivas e as experiências de homens reais:

A classe acontece quando alguns homens, como resultado de experiências comuns (herdadas ou partilhadas), sentem e articulam a identidade de seus interesses diferem (e geralmente se opõem dos seus). (...) Os homens e mulheres (...) retornam como sujeitos (...) não como sujeitos autônomos, "indivíduos livres", mas como pessoas que experimentam suas situações e relações produtivas determinadas como necessidades e interesses e com antagonismos, e em seguida "tratam" essa experiência em sua consciência e sua cultura (...) e em seguida (muitas vezes, mas nem sempre, através das estruturas de classe resultantes) agem, por sua vez, sobre a situação determinada. ${ }^{33}$

É importante notar que a experiência de classe é delimitada em grande medida, pelas relações de produção, nas quais os homens se inserem involuntariamente, e que delimitam as situações possíveis de serem vividas. Porém, tais experiências se expressam na consciência dos homens, na sua cultura: "A consciência de classe é a forma como essas experiências são tratadas em termos culturais encarnadas em tradições, sistemas de valores, ideias e formas institucionais". ${ }^{34}$ A "experiência" seria então o elo entre a totalidade das relações sociais de produção e o resultado das "situações" vividas.

A classe, de acordo com Thompson, portanto, pode ser pensada como condição social e material, submetida a permanente experimentação, (re)organização e luta. É, portanto, um grupamento em movimento, em permanente construção. ${ }^{35}$

Para o presente trabalho, é interessante que pensemos como o conceito de classe exposto, na realidade, designa algo cuja apreensão deve ser empiricamente enraizada. Não se determina sua existência - a priori, sem que se procure compreender como esta se forma num processo histórico e a partir de suas experiências. Da mesma maneira,

\footnotetext{
${ }^{31}$ THOMPSON, Edward P. A formação da classe operária inglesa. 1a ed. Rio de Janeiro: Paz e Terra, 1987, p. 9.

32 Idem, Ibidem, p. 10.

${ }^{33}$ THOMPSON, Edward P. A miséria da teoria ou um planetário de erros: uma crítica ao pensamento de Althusser. Rio de Janeiro: Zahar Editores, 1981, p. 182.

${ }^{34}$ THOMPSON, 1987, op. cit., p. 10.

${ }^{35}$ VITORINO, Arthur J. R. Notas sobre a teoria da formação de classe em E. P. Thompson. In: Historia Social. Campinas: № 4/5 1997/1998, p. 157-173.
} 
acreditamos que não se deve pressupor que grupos de interesse que se articulam em torno de um dado objetivo econômico, ou político devam ser necessariamente considerados representantes de interesses definidos de classe.

A experiência histórica da formação de classe passa, inclusive, pela construção discursiva de identidades diferenciais de classe. É através dessa definição do outro, em um contexto conflitivo, que se estabelece o caráter de pertinência a um dado grupo social.

Adotaremos aqui um conceito de classe como realidade histórica em processo, o qual se aproxima, portanto, da definição de E.P.Thompson.

Já a noção de fração de classe está presente em muitas análises associadas ao materialismo histórico. Para uma possível definição para esta noção, recorramos a Álvaro Bianchi:

Os capitais particulares não são idênticos entre si. Eles diferem das mais variadas formas - ramo de atividade, tamanho, localização -, ocupando lugares e momentos diferentes no processo de produção e reprodução do capital social. São estes diferentes lugares (...) que permitem falar de frações deste, conjuntos de capitais particulares que partilham condições comuns de realização e que, portanto, compartilham interesses. ${ }^{36}$

Ou seja, os capitalistas têm em conjunto o mesmo interesse, enquanto formam uma classe frente à outra classe, mas têm interesses opostos, antagônicos quando se defrontam entre si, na concorrência. Lembrando sempre que tais interesses não são dados atemporais atribuídos automaticamente a cada fração, e sim construções históricas determinadas. ${ }^{37}$

Existem várias possibilidades de se conceber as formas de fracionamento da classe dominante, numa sociedade capitalista, de acordo com múltiplas dimensões: as funções do capital (industrial, comercial, bancário, etc.), a origem espacial (pertinência a estruturas econômicas e políticas regionais), a escala de operações (pequeno ou grande capital), etc. A fração de classe não é algo dado e estático, havendo diferentes possibilidades de constituição, emergência, desaparição e cruzamento entre frações. ${ }^{38}$

\footnotetext{
${ }^{36}$ BIANCHI, Álvaro. Empresários e ação coletiva: notas para um enfoque relacional do associativismo. In: Revista Sociologia Política. Curitiba, 28, 2007a, p. 121.

${ }^{37}$ Idem, Ibidem, p. 122.

${ }^{38}$ FARIAS, op. cit., p. 89.
} 
Estes grupos, diferenciados na esfera econômica, não se concretizam de imediato, no plano político. Aglutinam-se concretamente em função de questões e interesses, para defender ou rejeitar aspectos da política estatal, por exemplo. Para Farias, um dado relevante é o de que a distribuição de poder e recursos entre frações é em geral assimétrica, introduzindo o potencial para o conflito. ${ }^{39}$

E desenvolvendo sua análise das frações de classe, Farias propõe a noção de "grupos multifuncionais", como "conglomerados econômicos que atuam em mais de uma esfera do capital". Porém, esse fenômeno não anula a existência de frações de classe, uma vez que tendem a sofrer o recorte dos interesses setoriais, em razão do impacto da política do Estado. Um subgrupo pode prevalecer politicamente no interior do grupo maior, sendo levado a defender políticas mais particularistas. É excepcional o caso em que a formação do grupo multifuncional coincide com uma política capaz de harmonizar os interesses específicos de cada fração. ${ }^{40}$

Para o período comumente denominado República Velha (1889-1930) é clássico o exemplo de um grupo multifuncional, o chamado "grande capital cafeeiro". Tal grupo teria se dividido entre suas várias dimensões (agrária, comercial, industrial), sendo que a política econômica do estado favorecia o prioritariamente a dimensão mercantil. $\mathrm{O}$ Estado, por meio de suas políticas, teve o papel de articular os interesses das várias frações de classe. A política de valorização do café era um desses elementos que articulava os interesses das frações do grande capital cafeeiro, mas significava um antagonismo, com outros grupos regionais. ${ }^{41}$

Assim, acreditamos ser teoricamente mais correto admitir que, quando é feita referência (como é comum) à indústria, ao comércio, ou à agricultura agroexportadora, ${ }^{42}$ estamos na realidade nos referindo a diferentes frações das elites econômicas brasileiras, caracterizadas socialmente pela busca da acumulação de capital. Uma vez tornado mais complexo e matizado o conceito de classe social, pelo conceito de fração de classe, coloca-se a questão: seriam agrupamentos de classe ou fração os únicos possíveis atores

\footnotetext{
${ }^{39}$ Idem, Ibidem, p. 81-2.

${ }^{40}$ Idem, ibidem, p. 83.

${ }^{41}$ Idem, ibidem, p. 93.

42 Ressaltamos que aqui não nos referimos à "agricultura em geral", apenas aquela de grande escala, voltada para a exportação de produtos de alto valor no mercado mundial, uma vez que há claros problemas em atribuir o caráter fração da classe capitalista à boa parte da atividade agrícola nacional, caracterizada pela produção para subsistência.
} 
num caso como o do Tratado? Seriam esses conceitos suficientes para dar conta da formação dos grupos no debate?

\subsubsection{O Problema da "representação" de classe}

Como tal terminologia é recorrente, cabe determinar o que se entende por “representação de classe". Segundo Emir Sader:

A relação que os representantes políticos de uma classe apresentam é determinada por mecânicas diferentes: eles se tornam representantes de uma classe quando sua apreensão não ultrapassa os limites que determina essa classe enquanto tal, levando-os teoricamente às mesmas soluções e aos mesmos problemas a que os interesses materiais e a posição social levam praticamente essa classe. ${ }^{43}$

O problema com essa compreensão, a nosso ver, se apresenta numa questão que o próprio Sader traz a tona, secundando Marx: é preciso distinguir entre os interesses "objetivos" da classe - e que na realidade, podem ser pensados como aqueles que se espera, teoricamente, que uma dada classe deveria ter e que deveriam se refletir em seu comportamento concreto em cada caso histórico particular -, e interesses "subjetivos", ou seja, aqueles que os próprios membros de uma dada classe (ou fração) concretamente evidenciam a partir de seu comportamento.

É fato que pode haver - e quase sempre há, em algum nível - uma defasagem entre eles. Como fica, então, a relação de representação? Pode acontecer um "deslocamento" nessa relação. Aquele que se poderia considerar um "representante" político de uma dada classe, dado que suas ações seriam "consistentes" com a defesa dos interesses subjetivos desta classe - ou aqueles os quais lhe são imputados -, pode num momento particular passar a ser, concretamente, um adversário político desta classe, diversos fatores de ordem prática ou ideológica, percebem seus interesses diferentemente.

Assim, nossa opção teórica não é pela rejeição da ideia de que um grupo político pode estabelecer uma relação de representação com uma classe que não o reconhece como seu próprio representante, ou que se opõe prática e/ou discursivamente a suas ações.

Pensamos apenas, que se deve qualificar o conceito de representação para que não incorramos no equívoco simplificador de atribuir à vontade ou às ações de uma classe toda e qualquer decisão política que favoreça a consecução de seus interesses "objetivos". Isto seria esquemático em demasia. Pior ainda, poderia obscurecer todo um conjunto de

\footnotetext{
${ }^{43}$ SADER, Emir. Estado e política em Marx. São Paulo: Cortez, 1998, p. 75.
} 
problemas fundamentais para a compreensão de aspectos fundamentais da complexa articulação entre as esferas política, econômica e cultural, num sentido amplo e em um caso histórico concreto.

\subsubsection{Elites políticas e a Burocracia}

Uma das possibilidades de se compreender as formações de grupos, em torno de interesses e identidades diferentes daquelas delimitadas pelo conceito de classe, ou fração de classe, seria partir do conceito de elites políticas. Este conceito derivou-se de uma tradição na filosofia política e nas ciências sociais, associada a autores como Vilfredo Pareto e Gaetano Mosca. Contudo, trata-se de um conceito que carrega problemas e, na forma na qual se apresenta originalmente, é antagônico ao conceito marxista de classe. ${ }^{44}$ Portanto, com a finalidade de avaliarmos a possiblidade de seu uso, é preciso submetê-lo a análise crítica.

Apesar de tal antagonismo conceitual, há correntes do materialismo histórico que procuraram se apropriar do conceito de elite e trazê-lo para o interior de seu campo teórico. Mas o fizeram modificando os próprios fundamentos do conceito. Segundo os cientistas sociais, Adriano Codato e Renato Perissinotto, a concepção marxiana mais geral, da natureza de classe do Estado capitalista não dá conta de: compreender sua configuração interna, seus níveis decisórios e as funções que os diversos centros de poder cumprem, seja como produtores de decisões, seja como organizadores políticos dos interesses das classes e frações dominantes. Nesse sentido, a função de mediação que o aparelho de Estado desempenha, através de suas atividades administrativas e burocráticas rotineiras, adquire aqui uma importância decisiva. ${ }^{45}$

Nas chamadas "obras históricas" de Marx e Engels, ${ }^{46}$ estaria presente uma análise na qual se observam as lutas políticas de grupos, facções e frações de classe, e é possível conceber o Estado como uma instituição dotada de recursos organizacionais próprios, que lhe conferem "capacidade de iniciativa" e de decisão. Na luta política concreta, os grupos políticos e as classes sociais percebem o Estado como uma instituição capaz de definir a distribuição de recursos diversos (ideológicos, econômicos, políticos) no interior da

\footnotetext{
${ }^{44}$ MARTUSCELLI, Danilo Enrico. Elite e classe dominante: notas sobre o marxismo inspirado na teoria das elites. In: Marxismo: teoria, história e política. São Paulo: Alameda, 2011. p. 157-177.

${ }^{45}$ CODATO, Adriano. e PERISSINOTTO, Renato M. O Estado como instituição. Uma leitura das 'obras históricas' de Marx. In: Crítica Marxista n. 13, out. 2001, p. 9-10.

${ }^{46}$ São citadas A Burguesia e a Contrarrevolução (1848), As Lutas de Classe em França de 1848 a 1850 (1850) e 018 de Brumário de Luís Bonaparte (1852).
} 
sociedade. Em função disso, lutam entre si para controlar diretamente ou influenciar à distância os diferentes ramos do aparelho estatal. ${ }^{47}$

A forma de funcionamento do aparelho de Estado possui certa autonomia, e que pode, no limite, afetar inclusive a funcionalidade do Estado e o processo de realização prática dos interesses da classe economicamente dominante. Marx, nas suas "obras históricas", abordou a forma conflituosa em que se desenvolvem as relações entre a burguesia e suas frações, por um lado, e os seus representantes políticos e os agentes estatais, por outro. $\mathrm{O}$ resultado desse processo histórico é construído em meio à dinâmica política e suas consequências não estão, em nenhum momento da análise de Marx, previamente acertadas. ${ }^{48}$

Partindo do reconhecimento dessas relações complexas entre classe e Estado, Adriano Codato defende o emprego da noção de elite política, na investigação da configuração histórica do Estado brasileiro. Segundo ele:

A elite política (...) [é] apenas uma parte daquele conjunto designado pelo nome 'classe dirigente' (...) [esta] englobaria também, além da elite política, todos os agentes que estão fora do Estado e fora do governo, mas que poderiam influenciar as decisões políticas (...) a elite política seria, por sua vez, uma subespécie da classe dirigente: é a parte da classe dirigente que estaria incumbida da tarefa de governar. $^{49}$

Este conceito de elite política, não substituiria o conceito de classe dominante, já que não seriam termos intercambiáveis. Segundo Codato, tal conceito pode ser assim definido:

Através desse termo (...), eu quero designar o grupo especializado de políticos profissionais (...) que controlam recursos políticos (posições institucionais no Estado, por exemplo) (...) e exercem as funções de governo (no Executivo e no Legislativo) (...). Os profissionais da política são (...) ligados às classes, camadas ou categorias sociais (por suas 'origens'), mas separados delas por suas funções e papéis no sistema de dominação. ${ }^{50}$

Aqui diferenciamos o uso do conceito de "elite" no campo da ciência política, do uso comum, tal como aparece na literatura não especializada, onde "elite" em geral refere-se ao conjunto de pessoas que, sem serem organicamente membros das classes

\footnotetext{
${ }^{47}$ CODATO e PERISSINOTTO, 2001, op. cit., p.17.

${ }^{48}$ Idem, Ibidem, p. 26.

${ }^{49}$ CODATO, Adriano N. Elites e instituições no Brasil: uma análise contextual do Estado Novo. Tese de Doutorado apresentada ao Programa de Pós-Graduação em Ciência Política do Instituto de Filosofia e Ciências Humanas da Universidade Estadual de Campinas, Campinas, 2008, p. 19.

${ }^{50}$ Idem, Ibidem, p. 19-20.
} 
dominantes, aderem a essas classes e as apoiam por interesses indiretos - clientelismo, tráfico de influência, privilégios, ou status, por exemplo.

A elite estatal seria formada pelo conjunto de pessoas que se encontram na cúpula das instituições do sistema estatal, controlando-as e exercendo o poder de Estado. Segundo Codato, estas "elites políticas podem, ou não, representar classes (...), mas elas cumprem essa missão, todavia, enquanto representam a sim mesmas", ou seja, possuem um conjunto de interesses comuns, empiricamente discernível e diverso do interesse mais imediato de classes ou frações dominantes. ${ }^{51}$ Ao mesmo tempo uma redefinição do termo "elite política" nos parece mais adequada, tendo em vista a não confusão com uma elite político-partidária.

Outra é a questão dos papeis dos ocupantes de posições no interior do Estado, a burocracia. ${ }^{52}$ Claude Lefort propõe uma definição, em consonância com a teoria marxista, nos seguintes termos:

\begin{abstract}
[A Burocracia] não é uma classe nem camada semelhante àquelas que podem ser distinguidas no interior de uma classe. (...) ela deve a sua existência à divisão da sociedade em classes, à luta de classes, pois sua função é a de fazer prevalecer as regras de uma ordem comum (...). A burocracia está 'normalmente' a serviço da classe dominante, (...) [porém] ela é mais que um simples segmento de classe, ela pode se chocar com certos de seus interesses, por pouco que um equilíbrio das forças sociais o permita, e adquirir então uma relativa autonomia. ${ }^{53}$
\end{abstract}

Os conceitos de elite e burocracia serão aqui propostos como hipótese para a tentativa de explicar a formação de grupos durante o debate acerca do Tratado. Cientes da problemática incorporação desses conceitos ao quadro teórico que escolhemos, procuramos fazê-lo com o cuidado de não postular uma excessiva autonomia desses grupos, em relação aos interesses das classes e frações mais relevantes.

Parece-nos claro que nas questões mais sensíveis da política estatal, não se verifica uma tendência a uma oposição entre os interesses específicos da elite política e da burocracia e o das frações da classe dominante. Contudo, da mesma forma que a tais frações não agem sempre em consonância e, por vezes, entram em aberto conflito,

\footnotetext{
${ }^{51}$ Idem, Ibidem, p. 25.

${ }^{52}$ Cabe ressaltar que o termo "Estado" está sendo utilizado, nestas passagens, na acepção do "estado restrito", ou "sociedade política" em termos gramscianos.

${ }^{53}$ LEFORT, Claude. O que é burocracia? In CARDOSO, F. H. e MARTINS, C. E. (Orgs.) Política \& Sociedade. São Paulo: Nacional, 1979, p. 149.
} 
também a elite burocrática pode posicionar-se de forma contraditória em relação a interesses imediatos das frações de classe dominantes. Dessa maneira, acreditamos que este conceito pode ser útil ao auxiliar na análise empírica do objeto do presente estudo.

Resta um último, porém importante, comentário acerca dos atores envolvidos nos debates acerca do Tratado. Não pretendemos aqui que nossa análise enfoque exclusivamente as classes, frações e grupos, mas também os indivíduos que os constituem. Pois, se a ação dos indivíduos não deve ser compreendida sem referências às totalidades maiores, as quais, ao mesmo tempo, são constituídas por e constituintes desses sujeitos individuais, também suas ações não são mecanicamente determinados pelas relações com tais sujeitos denominados "coletivos". As inclinações, ideias, atitudes e comportamentos pessoais também são fatores a serem levados em conta em qualquer análise histórica, porém, sem dúvida não de forma isolada ou fragmentária.

\subsubsection{Ideologia}

O conceito de Ideologia, central para a análise aqui empreendida, é polissêmico e recebe diversas definições, dentro e fora do campo teórico marxista. A ideologia é um complexo de ideias enraizado histórica e socialmente e, para Gramsci é a "unidade de fé entre uma concepção de mundo e uma norma de conduta adequada a essa concepção". 54 A ideologia é, para ele, um "médium” da hegemonia, a liderança cultural- ideológica de uma classe sobre as outras, que passa pela construção do consenso em torno de seus valores. Torna-se, assim, um elemento indissociável do exercício do poder por uma classe ou fração de classe, mas também pode servir à luta política contra esse poder. O conceito de ideologia em Gramsci enfatiza o papel das ideias nas transformações sociais. Nesse sentido, ele se aproxima de Marx, ao admitir que: "a teoria se transforma em poder material tão logo se apodera das massas". 55

É interessante notar que, na concepção inicial de Marx, o conceito de ideologia é em geral interpretado no sentido de uma "falsa consciência". Tal concepção é expressa na leitura de Marilena Chauí: "Este ocultamento da realidade social chama-se ideologia. Por

\footnotetext{
${ }^{54}$ GRAMSCl, op. cit., p. 111.

${ }^{55}$ MARX, Karl. Critica da filosofia do direito de Hegel. São Paulo, 1977, p.8
} 
seu intermédio, os homens legitimam as condições sociais de exploração e de dominação, fazendo com que pareçam verdadeiras e justas". 56

Já Gramsci afirma ser a ideologia uma concepção de mundo definidora e constituidora do real, ou seja, ela tem um aspecto "positivo", no sentido de que atua também de forma a criar e não somente reproduzir a realidade social. Daí que haja um espaço para as "ideologias" de emancipação. ${ }^{57}$ Este autor traça ainda uma distinção entre as ideologias historicamente orgânicas, as quais seriam "necessárias a uma determinada estrutura (...) e que organizam as massas humanas, formam o terreno no qual os homens se movimentam, adquirem consciência de sua posição, lutam, etc.”, das ideologias individuais, arbitrárias e, portanto, inócuas do ponto de vista dos processos sociais mais amplos. $^{58}$

Apesar das claras distinções apontadas, não acreditamos que tais visões sejam completamente irreconciliáveis. Ideologias são concepções do mundo e sua elaboração não cabe exclusivamente às classes dominantes. Também não são meros epifenômenos superestruturais, sendo elementos constitutivos do real, fundamentais para a estrutura de poder nas sociedades contemporâneas. Tais visões de mundo, porém, podem servir também como instrumentos de dominação social, ao escamotear conflitos e interesses, “distorcendo" assim, de certa forma, as percepções dos sujeitos.

Além desse sentido mais geral, o conceito de ideologia também foi aqui empregado numa acepção relativa ao "discurso ideológico", tal como é pensado por Terry Eagleton. Para este autor, a ideologia está sempre relacionada à luta política. Assim: “Dizer que um enunciado é ideológico significa, portanto, afirmar que está carregado de um motivo ulterior, estreitamente relacionado com a legitimação de certos interesses em uma luta de poder.". ${ }^{59}$ Ou seja, sempre que falarmos em discurso ideológico, estaremos falando da instrumentalização das ideias e representações do discurso para finalidades políticas subjacentes, que frequentemente não são explicitadas nem transparecem no próprio discurso. É através da análise que se pode tentar investigá-las.

\footnotetext{
${ }^{56}$ CHAUI, Marilena. O que é Ideologia. São Paulo: Brasiliense, 1981, p. 21.

${ }^{57}$ BRANDÃO, Nágela A. e DIAS, Edmundo F. A questão da ideologia em Antonio Gramsci. In: Trabalho \& Educação, vol.16, no 2, 2007.

${ }^{58}$ GRAMSCl, op. cit., p.237.

${ }^{59}$ EAGLETON, Terry. Ideologia: uma introdução. São Paulo: Boitempo, 1997, p. 28.
} 


\subsubsection{Hegemonia}

Trata-se de um conceito fundamental, uma vez que é ele que permite compreender como se dá concretamente a mediação entre economia, política e ideias, na teoria gramsciana. O termo "hegemonia" remete, em sua raiz grega, ao sentido de "liderança" e não foi uma invenção de Gramsci. Na realidade, Gramsci o empregou de forma proposital em um diálogo com os movimentos marxistas de sua época e, notadamente com o pensamento de Lênin. Contudo, o conceito de Hegemonia para Gramsci veio a adquirir um sentido próprio e bastante distinto.

Hegemonia, para Gramsci, pode ser entendida como a capacidade de direção intelectual e moral, através da qual a classe dominante, ou a que pretende tornar-se dominante, consegue sua legitimidade, obtém o consenso ou a aceitação passiva da maioria da população para suas determinações políticas. Nesse contexto, uma classe pode ser considerada hegemônica somente quando tiver conquistado o consentimento das classes subordinadas. ${ }^{60}$

Esse conceito gramsciano pode ainda ser desdobrado em dois significados distintos: (1) é o processo na sociedade civil pelo qual uma parte da classe dominante exerce o controle, através de sua liderança moral e intelectual, sobre outras frações aliadas da classe dominante, na medida em que é capaz de articular todos esses segmentos; (2) é também o processo pelo qual uma classe dominante é capaz de usar sua liderança política, moral e intelectual para impor sua visão de mundo como abrangente e universal, moldando os interesses e as necessidades dos grupos subordinados. Portanto, a hegemonia tem um componente horizontal (no interior da classe dominante) e um componente vertical (classe dominante sobre classe dominada). ${ }^{61}$

Para Carnoy, “A originalidade de Gramsci, como marxista, fundamenta-se em parte no seu conceito da natureza do domínio (...); de que a força verdadeira do sistema não reside na violência da classe dominante ou no poder coercitivo do seu aparelho de Estado, mas na aceitação por parte dos dominados de uma concepção de mundo que pertence aos seus dominadores". ${ }^{62}$ Enfim, "a hegemonia consiste no fato de, na sociedade

\footnotetext{
${ }^{60}$ SECCO, op. cit., p. 198.

${ }^{61}$ ALVERGA, Carlos F. R. P. de. Teoria marxista do estado capitalista: uma comparação entre Gramsci e Poulantzas. In: Jus Navigandi, abr/2011. URL: http://jus.com.br/revista/texto/18964/teoria-marxista-do-estado-capitalista-uma-comparacao-entregramsci-e-poulantzas, acessado em 16/08/2012.

${ }^{62}$ CARNOY, op. cit, p. 93.
} 
capitalista, a classe dominante conseguir convencer, persuadir a classe subalterna a aceitar e compartilhar seu sistema de crenças bem como seus valores sociais, culturais e morais". 63

Anita Schlessener enfatiza a articulação entre as concepções de hegemonia e do Estado em Gramsci:

A noção de hegemonia articula-se à concepção gramsciana de Estado (...) o poder é exercido através da sociedade política, composta pelos aparelhos administrativo-burocrático e político-militar, (...) [para] reprimir e disciplinar os grupos sociais que se opõem ao seu domínio; e da sociedade civil, formada pelas instituições que elaboram e/ou divulgam as ideologia, possibilitando a formação de consenso, base de sustentação das relações de poder. ${ }^{64}$

Porém, tal consenso não dá à classe dirigente o controle sobre toda a sociedade; o conflito, a divergência de opiniões, as contradições sociais, os movimentos por uma nova hegemonia podem exigir o uso da força. De fato, a hegemonia nunca representa um domínio total, absoluto, que não comporte visões discordantes e resistências contra hegemonias diversas. Daí a permanente relevância dos aparelhos privados de hegemonia e do Estado. De acordo com Carnoy: "Para Gramsci (...), o Estado, como um aparato ideológico ajuda a legitimar essa hegemonia e é, portanto, parte dela (...) [e] a responsabilidade decisiva dessa função legitimadora cabe aos intelectuais, tanto dentro quanto fora do Estado". 65

Álvaro Bianchi procura distinguir, no pensamento de Gramsci, o que chama de "hegemonia no sentido pleno", ou seja, "a direção política e cultural de uma classe revolucionária sobre o conjunto das classes subalternas"; do que denomina "hegemonia restrita", isto é, a "direção, em um período histórico no qual a classe dominante já perdeu a capacidade de assimilar a seu projeto as classes subalternas e, na qual uma fração das classes dominantes exerce sua função dirigente apenas sobre o conjunto delas por meio da mediação do Estado". ${ }^{6}$

Finalmente, cabe esclarecer o conceito de crise de hegemonia, no pensamento gramsciano. Tal crise ocorre quando existe equilíbrio de classes, ou seja, nenhuma classe

\footnotetext{
${ }^{63}$ ALVERGA, op. cit.

${ }^{64}$ SCHLESSENER, Anita Helena. Hegemonia e cultura em Gramsci. 3. ed. Curitiba: Ed. UFPR, 2007, p. 28-29.

${ }^{65}$ CARNOY, op. cit., p. 12.

${ }^{66}$ BIANCHI, Alvaro. Estratégia do contratempo: notas para uma pesquisa sobre o conceito gramsciano de hegemonia. In: Cadernos CEMARX. Campinas, no 4, 2007b. p. 9-39.
} 
social tem suficiente poder para arrebatar e conservar, sozinha, o controle do Estado. Nesse contexto, no qual nenhum estrato social consegue exercer sozinho o poder no Estado, a burocracia pode preencher o vácuo de poder, adquirindo autonomia relativa em relação à classe dominante e passa ela mesma a exercer o poder político.

\subsubsection{Projetos hegemônicos}

Choques entre diferentes frações do capital moldam o processo de sua reprodução. Portanto, é impossível falarmos em "interesses gerais do capital”, sem avaliarmos as relações de força entre estes grupos e o papel dos intelectuais orgânicos ${ }^{67}$ como mediadores na formulação dos interesses, dando coerência a essas necessidades, na forma de projetos políticos e econômicos. O nível de abrangência de tais projetos varia, sendo vinculado às relações de força político-ideológica. ${ }^{68}$

Bianchi propõe uma tipologia para estes projetos: projetos econômicocorporativos traduzem interesses econômicos imediatos de setores da produção, projetos hegemônicos restritos são "expressão da articulação dos interesses de diferentes ramos ou esferas da produção que construíram uma identidade econômica comum, mas que não são ainda capazes de afirmar um projeto de direção do conjunto da sociedade”. Já os projetos hegemônicos globais são aqueles por meio dos quais "um grupo afirma sua vocação de direção 'política, intelectual e moral' sobre o conjunto da sociedade, por intermédio da incorporação de demandas das classes subalternas". 69

\subsection{Um quadro mais geral - A Economia Mundial: Ciclos e hegemonias históricas}

A fim de situar o episódio estudado num quadro mais amplo e abrangente de processos, de "longa duração", é preciso especificar o que entendemos pelo conceito de Economia Mundial. A perspectiva que ora adotamos parte inicialmente da definição dada por Fernand Braudel para o conceito de "Economia-mundo", como sendo:

\footnotetext{
${ }^{67}$ Acerca dos intelectuais orgânicos, Bianchi esclarece, seguindo as ideias de Gramsci: "O desenvolvimento pleno de uma classe pressupõe que esta seja capaz de dotar-se de uma camada de intelectuais capaz de dar-Ihe homogeneidade e consciência de sua própria função, não apenas no campo econômico, como também nos terrenos da política e ideologia.". Cf. BIANCHI, 2007a, op. cit.

${ }^{68}$ BIANCHI, Álvaro. 2007a. p. 125-6.

${ }^{69}$ Idem, ibidem, p. 126.
} 
(...) um pedaço do planeta economicamente autônomo, capaz, no essencial, de bastar a si próprio e ao qual as ligações e trocas internas conferem certa unidade orgânica (...), embora dividida política, cultural, socialmente, admite uma certa unidade econômica (...) [e] é a mais vasta zona de coerência, em determinada época, em uma região determinada do globo. ${ }^{70}$

A Economia-mundo braudeliana é uma realidade histórica de longa duração, que possui limites no espaço, que lhe conferem um sentido. Possui um centro em beneficio de uma cidade, um capitalismo dominante, se constitui em um espaço hierarquizado, com periferias, numa soma de economias particulares, entre as quais se estabelece uma divisão internacional do trabalho. ${ }^{71}$ Como é uma realidade histórica, seus limites geográficos também são mutáveis no tempo. É assim que, essa "zona de coerência" sistêmica, pode transformar-se de Economia-mundo restrita à Europa, em uma Economia Mundial, com a expansão do capitalismo, que se consolida já no século XIX. E cada Estado se insere nesta realidade mais ampla em uma posição definida de sua hierarquia, a qual é relativa às suas capacidades históricas de acumulação de capitais.

Além dessa delimitação espacial, é fundamental insistir nas balizas históricas que a constituem. Giovanni Arrighi, partindo da concepção braudeliana do capitalismo como uma camada superior não especializada da hierarquia econômica, onde se realizam lucros extraordinários e que tem a flexibilidade necessária para deslocar continuamente seus investimentos das atividades econômicas que estejam enfrentando uma redução dos lucros ${ }^{72}$ definiu o conceito de "Ciclo Sistêmico de Acumulação".

A dinâmica dos ciclos sistêmicos se dá como segue: nas fases de expansão material, o capital monetário coloca em movimento uma massa crescente de produtos; nas fases de expansão financeira, uma massa crescente de capital monetário 'liberta-se' de sua forma mercadoria, e a acumulação prosseguem na forma financeira. Juntas, essas duas fases, constituem um ciclo completo.

\footnotetext{
${ }^{70}$ BRAUDEL, Fernand. Civilização Material, Economia e Capitalismo: séculos XV-XVIII. São Paulo: Martins Fontes, 1996, p. 13.

${ }^{71}$ Idem, ibidem, p. 13-34.

${ }^{72}$ ARRIGHI, Giovanni. O Longo Século XX. São Paulo: Editora UNESP, 1996. p. 8. A utilidade dessa definição de capitalismo - apesar dos problemas presentes ao se tentar sua apropriação ao materialismo histórico, devido às diferenças teóricas com relação conceito de "modo de produção", bem como as suas implicações para o conceito de "classe" -, reside justamente nessa ênfase dada à ideia de flexibilidade como traço distintivo desta camada, o que contribui para que se entenda sem problemas o processo de fracionamento da burguesia brasileira, em atividades econômicas diversas, sem que percam seu caráter fundamental de classe.
} 
Cada fase, além disso, corresponderia a um período de liderança de determinadas comunidades e blocos de agentes governamentais e empresariais, configurando Hegemonias sistêmicas e regimes particulares de acumulação, associados a um centro. A fase de expansão financeira marcaria ao mesmo tempo o apogeu e a crise de um dado ciclo, dando lugar a um período de transição, compreendido entre uma "crise sinalizadora", com a emergência de competidores cada vez mais fortes disputando o papel central e de diversas vias de desenvolvimento em choque; e uma "crise terminal", que marcaria, de forma muitas vezes violenta, a troca do centro. ${ }^{73}$

Os processos de "recentragem" das economias-mundo são definidos também por Fernand Braudel, que os identifica em diversos momentos da história do capitalismo. O que aqui nos importa especificamente seria aquele que resultou na transferência do centro econômico - e da hegemonia sistêmica - de Londres para Nova York, num um processo de longo prazo, que se torna claramente visível por volta de 1929.

A "crise terminal" do chamado Ciclo Hegemônico Britânico coincide, portanto, com a crise econômica mundial, a qual fornece o pano de fundo histórico para o Tratado. Compreende-se, assim, que, num período de crise sistêmica, deve haver diferentes estados (e estratégias) em disputa. Esse quadro subjacente à competição entre EUA e Alemanha, acompanha o declínio do Reino Unido, e se faz sentir com força no período que estudamos.

\subsection{Metodologia}

Para a realização do presente trabalho, procuramos partir de fontes, que, frente ao objeto de estudo que elegemos, se apresentam como essencialmente "qualitativas", ou seja, a ênfase é aqui atribuída aos significados e sentidos delas extraídos por um processo de análise e interpretação. O tratamento metodológico, portanto, foi definido a partir da dos problemas formulados, ${ }^{74}$ e das necessidades características da análise do tipo de documentos que pudemos recolher a fim de abordá-los, as quais, no caso, são fontes escritas de tipo diverso: atas parlamentares, atas de reunião em conselhos técnicos do governo e de associações de classe, correspondências diplomáticas e jornais. O objetivo, em primeiro plano, foi a análise dos discursos nelas contidos.

\footnotetext{
${ }^{73}$ ARRIGHI, op. cit. P. 218-245.

${ }^{74}$ Os problemas de pesquisa se encontram explicitados na seção “Problemas e Hipóteses de Trabalho".
} 
Os dados relevantes foram, portanto, obtidos por um método de análise textual inspirado na proposta de Cardoso e Vainfas (1997), o qual busca evidenciar: “(...) os nexos entre as ideias contidas nos discursos, as formas pelas quais elas se exprimem e o conjunto de determinações extratextuais que presidem a produção, a circulação e o consumo dos discursos (...)", ${ }^{75}$ ou seja, procuramos relacionar o discurso ao seu meio social e à temporalidade a eles específica, para a compreensão de seu significado histórico.

Dessa maneira, acreditamos que não se trata de uma análise dos discursos por si próprios, tal como se fosse possível descobrir somente em seu próprio conteúdo todas as determinações de seus significados. Procuramos enraizá-los em relação aos determinantes sociais, políticos, em suma históricos, que possibilitaram sua construção da forma concreta em que se apresentam. Torna-se possível assim um questionamento e análise críticos das informações extraídas da documentação, em face do conhecimento histórico disponível.

O conteúdo dos discursos passou a ser explorado em diversas dimensões: foram utilizados com a finalidade de identificação dos grupos que se conformaram no debate acerca do Tratado, a partir da análise do posicionamento dos participantes, tal como foi por eles expresso na ocasião; em seguida, partimos para uma análise de elementos biográficos dos participantes, visando identificar sua origem social e inserção política; procuramos ainda identificar e explicitar as ideias contidas nos discursos, com ênfase na identificação de elementos do pensamento econômico e visões sobre a política e sociedade, de forma que se tornasse possível uma análise de como tais ideias foram elaboradas - de que matrizes partiam, como foram apropriadas, etc. - e de como foram instrumentalizadas, a fim de defender determinadas posições e interesses subjacentes, identificando assim o seu papel histórico concreto. Finalmente, submetemos as conclusões obtidas ao contraste com a bibliografia existente.

\footnotetext{
${ }^{75}$ CARDOSO, Ciro Flamarion, e VAINFAS, Ronaldo. História e Análise de Textos. in: CARDOSO, C. F. (org.) Domínios da História - Ensaios de Teoria e Metodologia. São Paulo: Editora Campus, 1997, p. 376- 378.
} 


\subsection{Fontes}

As fontes utilizadas para a elaboração desta dissertação são de características variadas. Os documentos foram obtidos majoritariamente em arquivos, na forma de textos datilografados ou manuscritos, sejam eles originais ou fac-símiles, ou na forma digitalizada (on-line), quando disponível. Os documentos provenientes do CPDOC-FGV, por exemplo, se encontravam registrados em microfilmes, a partir dos quais foram extraídas cópias reprográficas. Quanto aos manuscritos, alguns deles eram de leitura difícil, devido à má-conservação e, portanto, boa parte deles precisou passar por um trabalho de interpretação.

Abaixo, encontram-se listadas as principais fontes primárias a serem utilizadas para esta dissertação:

- O texto do "Tratado de Comércio entre os Estados Unidos do Brasil e os Estados Unidos da América", assinado em 02 de fevereiro de 1935- obtido através do Decreto N. 542, de 24 de dezembro de 1935, que promulga o tratado e contém sua redação integral, além de um apêndice que traz as listas de produtos contemplados e suas respectivas tarifas; ${ }^{76}$

- Atas constantes dos Anais da Câmara dos Deputados, de 1935, obtidos no acervo da Biblioteca Nacional (RJ); ${ }^{77}$

- Correspondências diplomáticas oficiais entre a embaixada de Washington e o Ministério das Relações Exteriores, custodiadas pelo Arquivo Histórico do Itamaraty $(\mathrm{RJ})$;

- Correspondências, extraídas dos arquivos pessoais pertencentes ao embaixador Osvaldo Aranha, aos ministros Arthur da Souza Costa e José Carlos Macedo Soares e ao presidente Getúlio Vargas, custodiados pelo CPDOC-FGV (RJ);

- Atas de reuniões do Conselho Federal de Comércio Exterior (CFCE), custodiadas pelo Arquivo Nacional (RJ);

\footnotetext{
${ }^{76}$ Disponível on-line. URL: http://www2.camara.gov.br/legin/fed/decret/1930-1939/decreto-542-24-dezembro-1935-555656publicacaooriginal-74987-pe.html. Acessado em 10/11/2011.

${ }^{77}$ Disponíveis também on-line. URL: http://imagem.camara.gov.br/diarios.asp. Acessado em 12/06/2012.
} 
- Atas de reunião dos conselhos diretores da Sociedade Rural Brasileira (SRB), encontradas em seu arquivo histórico institucional, e documentos publicados pela Federação das Indústrias do Estado de São Paulo (FIESP);

- Jornais de ampla circulação e periódicos das associações de classe. 


\section{Capítulo 2 - As questões gerais da Historiografia}

A fim de que possamos melhor situar a problemática que orienta a presente pesquisa, é preciso antes realizar uma breve incursão em debates de cunho historiográfico e teórico acerca período estudado. Uma das questões mais relevantes a tratar é a de qual era o caráter do Estado, tal como se afigurava concretamente nessa conjuntura histórica particular. Qual era sua estrutura, a quais interesses e/ou a quais frações ou grupos representava, quem eram seus agentes, quais eram seus projetos políticos e qual era o arcabouço ideológico dele constitutivo, estão entre as questões mais importantes que se nos apresentam.

\subsection{Economia e Política: O Estado brasileiro e a industrialização na década de 1930}

A História Econômica que trata do período do Primeiro Governo Vargas apresentou debates interessantes acerca da natureza do Estado e de sua atuação na esfera econômica e, mais diretamente, sobre o papel do Estado no processo de industrialização.

Boris Fausto e Francisco Weffort apontam como elemento que caracterizou a política no período, a crise orgânica da aliança oligárquica vigente na Primeira República, ocorrida em paralelo com a ascensão de setores das elites, notadamente o setor industrial. Tais mudanças teriam resultado num quadro de indefinição, ou incapacidade do exercício da hegemonia por uma determinada classe, ou fração de classe, o que teria concorrido para a consolidação de uma forma política particular denominada Estado de Compromisso, assumindo o papel de "árbitro" de interesses, com relativa autonomia frente aos grupos em conflito. ${ }^{78}$

Para Eli Diniz, nessa conjuntura, as perspectivas de participação na elaboração da política governamental por parte de elementos das elites industriais se amplificaram, na medida em que um conjunto de interesses próprios gradualmente se configurava. A atuação dos representantes da classe industrial teria caracterizado um novo estilo de participação em decisões políticas, agora em moldes corporativos. Os conselhos técnicos, tais como o Conselho Federal de Comércio Exterior (CFCE), tornaram-se locais

\footnotetext{
${ }^{78}$ FAUSTO, B. A revolução de 1930: historiografia e história. São Paulo, Companhia das Letras, 1997 e WEFFORT, F. O populismo na política brasileira. 4a ed. Rio de Janeiro, Paz e Terra, 1989.
} 
privilegiados para a participação dos industriais em decisões relativas às políticas econômicas.

Tal participação teria sido pautada por conflitos e negociações em torno de interesses e concepções ideológicas divergentes ou antagônicas. Entre as disputas ali travadas, teve destaque a controvérsia entre políticas liberais e protecionistas ou "nacionalistas". A autora caracteriza a orientação fundamental do empresariado industrial como "nacionalista", tendo como objetivo: "a defesa da produção interna, tendo em vista a superação gradual da condição de importador de manufaturados". 79

Segundo Diniz, tais conflitos e embates, em seu plano mais estrutural, corresponderiam à gradual diferenciação de interesses entre os grupos, ou frações de classe, constituintes das elites dominantes. Partindo de um pequeno grau de contradição entre os interesses de uma elite agrária e uma elite industrial, característico por definição do chamado capital cafeeiro, observa-se a constituição, lenta e conflituosa, de um conjunto de demandas e projetos políticos mais particularizados e característicos das distintas frações das classes dominantes. ${ }^{80}$

A década de 1930 teria assim sido um período marcado, do ponto de vista da atuação dos industriais, como tendo sido palco de uma disputa ideológica e um processo de conscientização. Segundo Diniz, os industriais tiveram um papel de "intérpretes do advento de uma nova ordem econômica (...). Tratava-se de uma oportunidade para destruir os argumentos anti-industrialistas”. Parece claro, a partir da análise desta autora, como teria sido necessário romper com a hegemonia das concepções "tradicionais", ou seja, aquelas ligadas à visão de um Brasil agrário:

Durante os primeiros anos da década de 30 o pensamento oficial revelaria ainda seus compromissos com a perspectiva de subordinar o desenvolvimento da indústria aos interesses das atividades econômicas tradicionais. (...) Claro esta que tais pronunciamentos não podem ser interpretados como indicador da subordinação do novo governo ao poder dos grupos econômicos tradicionais, (...) a linguagem oficial visava sobretudo a apaziguar setores significativos da aliança política que permitira a vitória do movimento de 30 ". Contudo, segundo a autora, "revela as profundas resistências à defesa de uma posição francamente industrialista, inseridas na própria estrutura de poder. ${ }^{81}$

\footnotetext{
${ }^{79}$ DINIZ, Eli. Empresário, Estado e Capitalismo No Brasil: 1930/1945. Rio de Janeiro, Paz e Terra, 1978.

${ }^{80}$ DINIZ, Eli. O Estado Novo: estrutura de poder e relações de classe. In FAUSTO, Boris (ed.). História geral da civilização brasileira. O Brasil Republicano. 3a ed., São Paulo: Difel, 1986, tomo III, vol. 3.

${ }^{81}$ DINIZ, 1978, op. cit., p. 125.
} 
No que concerne mais propriamente às relações entre Estado e industrialização, um amplo debate se desenvolveu. Seu ponto de partida foi a conformação de uma tradição interpretativa inaugurada por Celso Furtado, ${ }^{82}$ a qual atribui o crescimento da indústria brasileira na década de 1930 às políticas governamentais adotadas frente ao "choque externo adverso" da crise mundial para a defesa da economia cafeeira. Porém, segundo sua tese, tais políticas teriam sido postas em prática sem qualquer intenção prévia de promover a industrialização, ou seja, as políticas que favoreceram a industrialização teriam sido um subproduto da defesa do café.

Já Warren Dean representa uma vertente interpretativa, segundo a qual, no início do governo Vargas, a reavaliação das políticas econômica e externa teria partido de uma visão "hostil aos industriais", pois "nada em sua educação econômica [dos membros do governo] the dera a entender que a industrialização do Brasil fosse assunto urgente". ${ }^{83}$ Dean parece, portanto, corroborar a tese de Furtado, ao afirmar que as opções políticas de Vargas no início de seu governo não foram inspiradas em uma política de governo voltada à promoção da indústria, mas foram antes resultantes das dificuldades cambiais crônicas.

Ainda segundo Dean, entre 1932 e 1937, "Vargas baseou sua política econômica numa expectativa de que o livre comércio internacional viesse a se restaurar de uma forma qualquer" ${ }^{84}$ Dessa maneira, teria conduzido a política comercial externa tendo em vista, prioritariamente, os interesses da agroexportação. O que, segundo Dean, impedia a reorientação da política oficial era, entre outras coisas, "a atitude dos industriais, incapazes de convencer os fazendeiros, a classe média, ou a burocracia de que, zelando pelos seus interesses particulares, eles estariam zelando pelos interesses do Brasil". ${ }^{85}$

Contrariamente, Stanley Hilton afirma que "Vargas esteve comprometido com uma política de crescimento balanceado e que a industrialização, consequentemente, tinha alta prioridade em sua lista de objetivos nacionais desde o inicio", ${ }^{86}$ avaliação que

\footnotetext{
${ }^{82}$ Cf. FURTADO, Celso. Formação Econômica do Brasil. São Paulo: Ed. Nacional, 1985, cap. XXXI.

${ }^{83}$ DEAN, Warren. A industrialização de São Paulo, 1880-1945. 3a ed., São Paulo: Difel, 1971 [1969], p. 195.

${ }^{84}$ Idem, Ibidem, p. 209.

${ }^{85}$ Idem, Ibidem, p. 220.

${ }^{86}$ HILTON, Stanley. Vargas and Brazilian economic development, 1930-1945: A reappraisal of his attitude toward industrialization and planning. Journal of Economic History. 35, Dez 1975, p. 756. A tradução é nossa.
} 
se reproduz em outra obra deste autor. ${ }^{87}$ Hilton ainda discorda de Dean, com relação aos princípios orientadores da política econômica: “durante o período chave de 1930-1937, as ideias econômicas e as políticas da administração Vargas de forma alguma se centraram na manutenção da divisão de trabalho internacional anterior à Primeira Guerra Mundial". ${ }^{88}$ A tese defendida por Hilton, assim como no caso de Dean, se apoia fundamentalmente em elementos discursivos. ${ }^{89}$

Já Pedro C. Dutra Fonseca defende que há evidencias empíricas da intencionalidade na promoção da industrialização. Porém, tais evidências não deveriam ser buscadas na análise dos discursos oficiais, ou das políticas econômicas instrumentais, visto que nem sempre são reveladoras das intenções que as motivaram, e sim no exame das instituições criadas e alteradas no período.

Estas representariam mecanismos, regras e arenas de disputa dentro do aparelho de Estado, onde grupos foram capazes de reorientar a economia, definindo uma nova relação entre Estado, empresários, trabalhadores e o mercado. A criação dos conselhos técnicos federais, institutos como o do café e da borracha e outras instituições, que contaram com a participação ampla de industriais e pautaram sua atuação em conformidade com seus interesses, seria evidência clara dessa orientação a favor da indústria..$^{90}$

Fundamental para o presente trabalho também é a compreensão do papel da burocracia estatal nessa relação entre Estado e industrialização. Luciano Martins, em sua tese de doutorado afirma que a transformação capitalista teria sido conduzida, na ausência de uma burguesia politicamente dirigente, e a base de uma coalisão elitista de formato oligárquico, elegendo a "moderna burocracia econômica" que emergiu na década de 1930 como o grande ator histórico do processo de industrialização. ${ }^{91}$

Como se pode ver, trata-se de questões bastante relevantes para uma análise histórica abrangente sobre o período. Tais questões serão colocadas em pauta nas análises

\footnotetext{
${ }^{87}$ Cf. HILTON, Stanley E. O Brasil e as grandes potências: aspectos políticos da rivalidade comercial. Trad. Carlos Nelson Coutinho. Rio de Janeiro: Civilização Brasileira, 1977, p. 46.

${ }^{88}$ Idem, Ibidem, p.756.

${ }^{89}$ Idem, Ibidem, p. 771.

90 FONSECA, Pedro C. D. Sobre a intencionalidade da política econômica industrializante do Brasil na década de 1930. In; Revista de Economia Política. 23 (1), janeiro/março 2003, pp. 134-5.

${ }^{91}$ MARTINS, Luciano. "Pouvoir politique et developpement economique, structures de pouvoir et systeme de decisions au Bresil”, tese de doutoramento. Universidade René Descartes, apud. DRAIBE, 2004, p. 22.
} 
que aqui faremos da documentação relativa ao debate sobre o Tratado, seja em âmbito parlamentar, no interior das associações de classe, na imprensa, ou no seio do próprio governo federal.

\subsection{Sociedade: Classes e Frações de classe no Brasil da década de 1930}

Edgard Carone se vale de elementos da clássica interpretação de Celso Furtado, para explicar as circunstâncias nas quais se deu a lenta passagem para o predomínio de uma burguesia industrial sobre as antigas elites agrárias, cujo marco inicial se situa na década de 1930. Em suas palavras, "declínio agrícola geral e reerguimento da produção industrial representam a dialética do período". O amadurecimento desse processo, bem como a plena consciência dele por parte das autoridades governamentais, teria vindo só no final da década. ${ }^{92}$

A crise econômica mundial é o elemento de ruptura que "abala todo o alicerce econômico" e teria permitido uma reconfiguração sócio-política. Com a quebra do sistema de poder das oligarquias agrárias, a ascensão da emergente burguesia se fez possível. Mas se houve, segundo Carone, uma "decadência das classes agrárias e a ascensão da burguesia", não se deve tomar este processo como uma ruptura radical, nem sequer na medida em que se apresentava ainda incipiente no período em questão. De fato, Carone insiste a todo tempo na pouca diferenciação - na realidade, quase indiferenciação - político-ideológica entre elite agrária e burguesia, ambas com tendências profundamente conservadoras.

A Revolução de 1930 é o momento que marca a queda do antigo sistema político (...) e é também o início do processo de declínio do sistema agrícola. Esta passagem leva à falsa ideia de que 1930 representa, automaticamente, a ascensão absoluta da indústria e da burguesia. Em primeiro lugar, há a diferença entre a queda politica das oligarquias agrárias, dominadas pelo café, e a quebra de predomínio do sistema agrícola (...) a composição de poder após 1930 é grandemente agrícola (...). Daí o sistema político-social dominante ainda ser em grande parte de origem agrícola. ${ }^{93}$

Ainda há clara proximidade de interesses entre os grupos, a qual tem raízes nas origens sociais da própria elite industrial:

São de capitais da agricultura e da pecuária que se originam grande parte das indústrias e dos bancos nacionais (...), o que mostra a ligação de interesses entre

\footnotetext{
${ }^{92}$ CARONE, Edgard. A república nova: 1930-1937. São Paulo: DIFEL, 1974, p. 5.

${ }^{93}$ Idem, ibidem, p. 82.
} 
ambos (...). Os interesses comuns é que explicam a prática inexistência de choques entre agricultura e indústria. (...) [Os líderes industriais] defendem seus interesses, mas acentuam sempre a importância das atividades agrícolas. Após 1930, continua-se a bater em favor da agricultura e pela ajuda do governo aos agricultores. ${ }^{94}$

No mesmo sentido, se manifesta Décio Saes, acerca do chamado "grande capital cafeeiro":

O grande capital cafeeiro (...) é um grupo dominante multifuncional ou polivalente (...), portanto, diferentes interesses econômicos (...). Caso os portadores de tais interesses fossem grupos sociais diferenciados (e não um só grupo social como no caso em pauta), seria inevitável o conflito entre eles. ${ }^{95}$

Segundo Sérgio Silva, o "capital cafeeiro": "apresenta ao mesmo tempo as características do capital agrário, do capital industrial, do capital bancário e do capital comercial." $\mathrm{Na}$ economia cafeeira, caracterizada por um grau ainda fraco de desenvolvimento capitalista essas diferentes funções eram reunidas pelo capital cafeeiro e não definem frações de classe relativamente autônomas: havia apenas uma burguesia cafeeira exercendo múltiplas funções. ${ }^{96}$

Para Carone, a década de 1930 assiste a uma transformação gradual na problemática da identificação social entre os setores das elites - ou frações de classe. Nesse momento "confundem-se, ainda, os dois interesses e as duas frações, aparentemente sobressaindo como elemento dominante a dos grupos agrários". ${ }^{97}$ Dessa forma, Carone reconhece a permanência de a hegemonia dessa fração, em no seio de um bloco de classes bastante próximas quanto a seus interesses mais amplos, mas já com certa diferenciação no que tange a alguns interesses mais imediatos.

Neste momento, acreditamos que a concepção de Eli Diniz pode contribuir para melhor compreender os processos em curso nesse período, já apontados por Carone. Para esta autora, de fato havia pouca diferenciação social entre as frações principais da burguesia. Porém, o que é possível verificar a partir do início do século - e, mais claramente no período do Entreguerras (1918-1939) - é que passa a haver uma "crescente

\footnotetext{
${ }^{94}$ Idem, Ibidem, p. 83.

${ }^{95}$ SAES, Décio. Estado capitalista e classe dominante. In: Crítica Marxista, n.12, 2001, p. 157.

${ }^{96}$ SILVA, Sérgio. Expansão cafeeira e origens da indústria no Brasil. São Paulo: Alfa-Ômega, 1976.

${ }^{97}$ CARONE, op. cit., p. 83.
} 
diferenciação" de interesses entre tais frações, o que se reflete na configuração de formas de representação política gradualmente diferenciadas. ${ }^{98}$

Sônia Draibe, em seu amplo estudo sobre as relações entre o Estado, a industrialização e os projetos e interesses de classe no Brasil, apresenta uma perspectiva com a qual concordamos em muitos pontos. A autora define as "classes ou frações de classe fundamentais", como aquelas que seriam historicamente capazes de ordenar, a partir de seus interesses estratégicos objetivos, o conjunto da sociedade. Em outros termos, é pela capacidade de generalização, de transformação de seus próprios interesses econômicos, sociais e políticos em interesses de amplos setores da sociedade, convertendo-se em base do Estado.

A autora identifica como classes fundamentais a burguesia mercantil-exportadora, a burguesia industrial e o proletariado. Cada um desses setores constituía uma base de interesses capaz de propor diferentes "vias de desenvolvimento", ou seja, alternativas para equacionar as questões da transformação assinalada como "revolução burguesa". Tais vias não constituíam, contudo, projetos determinados de antemão pelas forças políticas em luta, resultando do enfrentamento de tais forças pela conquista e direção do Estado e concretizando-se em torno de projetos que aspiravam à formação de coalizões e articulações, ou seja, de blocos dirigentes. ${ }^{99}$

\begin{abstract}
A crise da economia cafeeira, que atingiu seu clímax com a depressão dos anos de 1930, representou a possibilidade de ruptura de sua forma de inserção no âmbito da economia mundial capitalista. (...) Mas o estabelecimento da dominância do capital industrial, como novo eixo da acumulação capitalista, não se deu como um desenlace, deduzido abstratamente a partir das condições estruturais (...) a severidade do colapso que atingiu frontalmente a economia mercantil-exportadora abriu diferentes alternativas de desenvolvimento capitalista, (...) nenhuma delas estava, automaticamente determinada a priori como solução para o futuro. No contexto da crise, qualquer das alternativas implicaria, para sua materialização, uma nova política no interior do Estado e, simultaneamente, uma transformação do próprio Estado. ${ }^{100}$
\end{abstract}

Draibe defende que os interesses do capital cafeeiro tinham condições de propor e sustentar uma via de desenvolvimento própria nas condições abertas em 1930. Sua dominação admitiria e até mesmo necessitaria da expansão paralela de um setor industrial de bens de consumo. Porém, tal expansão dependeria de políticas e investimentos de Estado que, no limite, poderia vir a significar a subordinação de seus interesses às

\footnotetext{
${ }^{98}$ DINIZ, 1986, op. cit.

99 DRAIBE, Sônia. Rumos e Metamorfoses: um estudo sobre a constituição do Estado e as alternativas da industrialização no Brasil. Rio de Janeiro: Paz e Terra, 2004, p. 22-26.

${ }^{100}$ Idem, ibidem, p. 25.
} 
prioridades da regulação estatal. A forma de vinculação "tradicional" à economia mundial, da qual o capital cafeeiro dependeria, requeria uma política liberal (de câmbio e tarifas), que visasse o suprimento mais conveniente de bens manufaturados.

Já aí apareceria uma contradição potencial com interesses objetivos da burguesia industrial, a qual, partindo de um estágio precário de concentração e centralização de capital, requerendo políticas econômicas de suporte do Estado, em termos de crédito, proteção tarifária, disponibilidade cambial, gastos em infraestrutura, etc. ${ }^{101}$ Ainda que não estivesse mecanicamente determinada por essa contraposição de interesses objetivos, uma oposição de projetos políticos e objetivos imediatos, poderia surgir, como de fato teria ocorrido em certas ocasiões específicas:

Em seu projeto de industrialização, a burguesia industrial enfrentaria a oposição dos setores ligados ao café em várias dimensões da política econômica. Na ruptura de suas relações de dependência com o setor exportador, tenderiam a divergir quanto à política cambial, a politica tarifária (...), à politica monetária, de gasto publico e à política creditícia. ${ }^{102}$

No âmbito do presente estudo, nos coube verificar, concretamente no caso em questão, qual foi a configuração de interesses em jogo e responder à indagação de se o referido conflito entre interesses de classes ou frações de classe foi fator determinante para o processo. Afinal, especificar quais interesses estavam em jogo, quem de fato os defendeu e por que, são questões que procuramos abordar nessa dissertação.

\subsection{As Ideias - pensamento econômico e político}

Ao fazer uma análise do pensamento dos industriais brasileiros, Mariza Leme, propõe uma distinção entre o que chama de um "campo econômico" e outro, "social e político", constitutivos de sua ideologia de classe. Para justificar tal divisão, a autora contrapõe o caráter inovador do pensamento econômico dos líderes industriais ao conservadorismo intrínseco de suas visões sobre a sociedade e a política. ${ }^{103}$

Se de um lado os industriais elaboram um pensamento sobre as questões prementes para a economia nacional, pautado pela defesa de uma industrialização ativamente promovida pelo Estado e pelo questionamento de aspectos fundamentais das

\footnotetext{
${ }^{101}$ Idem, ibidem, p. 25.

102 Idem, ibidem, p. 30.

103 LEME, Mariza Saenz. O pensamento industrial no Brasil: 1919-1945. Dissertação de Mestrado apresentada ao departamento de História da Faculdade de Filosofia, Letras e Ciências Sociais da Universidade de São Paulo, 1976, p. 272.
} 
ortodoxias econômicas liberais, o que seria elemento de nítida diferenciação desse grupo em relação aos demais setores da classe dominante; por outro lado suas concepções sobre a política seriam marcadas pelo combate a todo movimento organizado da classe trabalhadora, a oposição às chamadas "leis sociais" (trabalhistas, previdenciárias, direitos de organização, etc.) e uma visão elitista da sociedade. Todos estes traços seriam elementos de aproximação com as elites agrária e comercial, contribuindo para configurar uma identidade mais ampla das "classes dirigentes". ${ }^{104}$

Não discordamos aqui, em essência, do conteúdo da análise de Leme, quanto à distinção sugerida acima. Contudo, nossa abordagem ao invés de ressaltar tal cisão entre um "pensamento econômico", de caráter progressista, e um "pensamento social e/ou político", de caráter conservador, procura apreender a totalidade deste "pensamento dos industriais" - inserido sempre no quadro mais amplo das ideias que circulavam no seio das classes capitalistas do Brasil naquele período. Trata-se de entender não porque havia uma diferença entre pensamento político e econômico - tal como se ambos fossem claramente dissociáveis -, mas de compreender como concretamente se deu essa articulação entre uma visão inovadora em economia e um arraigado conservadorismo em matéria social e política.

Uma primeira aproximação pode ser feita ao se constatar as origens sociais da semelhança de posições quanto às questões políticas mais substantivas. De fato, um grande número de estudos já elucidou as origens sociais intrinsecamente vinculadas, quando não idênticas, das elites agrária e industrial. Antes de tudo, constituíam frações, ainda não fortemente diferenciadas, de classes capitalistas em formação, numa sociedade pautada pela extrema desigualdade legada por seu passado colonial e escravista. Defendiam, no plano ideológico, concepções autoritárias e excludentes em política, que podem ser interpretadas como ligadas intimamente à preocupação concreta com a manutenção de seus privilégios. Refletiam, ademais, a permanência de uma cultura política fortemente autoritária.

Além disso, as questões e problemas políticos com os quais aqueles setores das elites se defrontavam certamente não eram os mesmos que se apresentavam nos países centrais. E isto, claramente, se relaciona com o nível de maturidade dos movimentos sociais e de articulação e complexidade, constitutivas da sociedade civil, no sentido gramsciano. Assim, tal conservadorismo torna-se compreensível a partir de uma

\footnotetext{
${ }^{104}$ Cf. LEME, op. cit..
} 
apreensão histórica das bases concretas de formação desse pensamento social e político. Mas, permanece ainda intocada a questão da sua articulação com um pensamento econômico, que em certos sentidos pode ser caracterizado como "progressista".

Primeiramente, cabe esclarecer o conteúdo desse caráter "progressista". Já de início, porém, reconhecemos o caráter problemático dessa denominação. Mas, a fim de entender as diferenças concretas nos sentidos históricos das concepções ideológicas que estudamos - se objetivavam uma permanência, ou alternativamente a modificação ou transformação mais ou menos rápida de estruturas sociais, econômicas políticas e até de elementos da cultura -, é que pautaremos, por ora, nossa discussão nessa oposição conceitual.

\subsubsection{Ideias Econômicas ${ }^{105}$}

Leme aponta um aspecto diferenciador do pensamento econômico industrial na década de 1930. Segundo ela, enquanto as "posições conservadoras" do comércio e da agricultura seriam "totalmente parciais na defesa dos seus interesses", representando o Brasil como país essencialmente agrário e exportador, os líderes industriais formularam um projeto de desenvolvimento conjunto do país. ${ }^{106}$ Tal elemento deve ser, contudo, recolocado em uma perspectiva histórica e relacionado às questões centrais que aqui abordamos.

A hipótese da qual partimos - e que será desenvolvida mais adiante - é a seguinte:

a) Isto se explica, ao menos em parte, devido ao fato de que os grupos industriais, representados no debate, estariam preocupados em construir um novo consenso, diferente do ainda vigente, no que concerne a questões fundamentais da política econômica.

b) Tratava-se principalmente de remodelar as próprias concepções sobre o caráter do Brasil e de sua inserção na economia mundial.

Portanto, explica-se por que, ao formular seu projeto político-econômico, a fração industrial da burguesia brasileira precisou necessariamente abarcar o "todo" da economia nacional. Já o "comércio e a agricultura", ou mais propriamente os representantes dessas

\footnotetext{
${ }^{105}$ Para uma análise de conjunto sobre o pensamento econômico no período, ver: LIMA, Heitor F. História do pensamento econômico no Brasil. 2a ed. São Paulo: Cia. Ed. Nacional, 1978 e de BIELSCHOWSKY, Ricardo. Pensamento econômico brasileiro: 1930-1964 O ciclo ideológico do desenvolvimentismo. Rio de Janeiro: Contraponto, 2001. E como uma referência geral sobre o pensamento econômico, adotamos SCREPANTI, Ernesto \& ZAMAGNI, Stefano. An Outline of the History of Economic Thought. Oxford: Oxford University Press, 2005 e HUNT, E. K. História do pensamento econômico. Trad. José Ricardo Brandão Azevedo e Maria José Cyhlar Monteiro. Rio de Janeiro: Elsevier, 2005.

${ }^{106}$ Idem, Ibidem, p. 273.
} 
frações de classe, partindo de concepções ainda predominantes, segundo as quais seriam eles os setores essenciais (senão os únicos verdadeiramente relevantes) de nossa vida econômica, podiam dar-se ao luxo de arquitetar um projeto que se nos afigura hoje mais "parcial", mas que ainda se arrogava à legitimidade de um projeto nacional, mesmo quando a sua clara hegemonia parecia estar a ser ameaçada por aqueles setores capitalistas emergentes.

Para Leme, o período que vai de 1919 a 1945 pode ser dividido, no que se refere ao pensamento da fração industrial da burguesia, em um período inicial, caracterizado por uma postura "defensiva" frente aos demais setores, na busca de demonstrar a importância prática da sua existência como categoria e classe (ou, em outras palavras, a sua legitimidade), e um período que se caracteriza, já no início da década de 1930, por uma postura mais "ofensiva", reivindicando a igualdade de condições da indústria e a colocando necessidade de sua proteção pelo Estado como questão de "interesse geral".

Este último período ainda comportaria uma subdivisão, visto que seria em meados da década, ou mais precisamente, após 1935, que tal postura amadurece, permitindo a tradução desses propósitos na formulação de um verdadeiro projeto para a economia nacional. Acreditamos que, interpretado de acordo com a proposição implícita na periodização proposta, o Tratado de 1935 aparece como momento essencial nesse processo de amadurecimento da identidade e do pensamento do setor industrial, principalmente no que se refere aos aspectos relativos à "dimensão externa" da problemática relativa ao pensamento desse setor. Segundo Leme, é a partir de 1935 que se teriam se configurado claramente as diretrizes que viriam a orientar os industriais nos anos subsequentes. ${ }^{107}$

Tais diretrizes seriam de forma simplificada: a obtenção de uma política financeira estável, o aumento do poder aquisitivo médio da população, o aumento da produtividade, uma união entre agricultura e indústria, a captação de capital externo, direcionado para investimentos produtivos e a adoção de uma política comercial externa bem definida. Fica claro, após a análise da documentação estudada que o debate sobre o Tratado de 1935 colocou em pauta todas essas questões. E, seguindo a própria análise de Leme, nos parece que, principalmente no caso desta última diretriz, bem como para a o amadurecimento e a consolidação da totalidade desse corpo de diretrizes, na forma do esboço de um projeto mais amplo, o episódio aqui estudado foi momento fundamental. ${ }^{108}$

\footnotetext{
${ }^{107}$ LEME, op. cit., p. 289.

108 Idem, ibidem, p. 282.
} 
Para Leme, a chamada "lavoura" (aqui entendida como a fração de classe ligada à produção agrícola para exportação) defenderia a tese de que o Brasil deveria manter, ou acentuar, sua especialização na produção de matérias primas e alimentos e importar produtos industrializados. Criticava-se ainda o "protecionismo criminoso" reivindicado pelos industriais, bem como a substituição da tarifa então vigente, que se considerava ter o objetivo "proteção industrial", por uma "tarifa de renda aduaneira" - sistema em que é cobrada uma porcentagem geral mínima sobre os produtos importados.

O fundamento ideológico dessas disposições estaria numa visão de que o Brasil seria um país "essencialmente agrário", tendo em vista que não possuía todos os elementos necessários para o "desenvolvimento natural" da indústria, dado que lhe faltavam reservas de carvão e ferro, condições técnicas de produção, uma densidade populacional adequada e riqueza acumulada. Qualquer tentativa de se implantar aqui uma indústria moderna e de larga escala era representada, portanto, como "artificial" e danosa para a coletividade nacional. ${ }^{109}$

A redução das tarifas aduaneiras, aliada à abolição do imposto de consumo, não traria prejuízos ao fisco, uma vez que seria assim gerado um aumento do volume de importações e exportações. Toda esta argumentação pode ser encontrada no documento Bases de orientação para uma reforma do sistema aduaneiro no Brasil, publicado em 1931, pelo Instituto do Café de São Paulo, também citado por Leme.

Segundo Arruda, as concepções dos agentes ligados ao comércio de exportação tendiam a exibir proximidades claras com as da "burguesia cafeeira":

\begin{abstract}
A burguesia cafeeira (...) foi uma grande aliada do comércio importador na luta contra o protecionismo alfandegário, atitude que facilitou a entrada de mercadorias estrangeiras e atrasou o processo de instalação de importantes indústrias no país (...) ambos eram favoráveis à desvalorização da moeda local. Num curioso movimento de transplantação ideológica, os Ricardianos periféricos, ainda impregnados de alguns velhos preconceitos fisiocráticos, insistiam no trinômio 'essencialmente agrícola / vantagens comparativas / indústrias fictícias’ para desqualificar as pretensões do movimento industrialista. ${ }^{110}$
\end{abstract}

A resposta dos líderes industriais era a de que a indústria e a agricultura não seriam atividades antagônicas, e sim complementares, carecendo ambas de proteção tarifária. Tal posição ficou clara nos discursos e textos produzidos por Roberto

\footnotetext{
${ }^{109}$ Idem, ibidem, p. 282-6.

${ }^{110}$ ARRUDA, Pedro F. Capitalismo Dependente e Relações de Poder no Brasil: 1889-1930. São Paulo: Expressão Popular, 2012, p. 327.
} 
Simonsen ${ }^{111}$ e é reproduzida por vários representantes dos industriais no debate aqui estudado.

É também notável o fato de que ao longo da década, consolidou-se uma nova hierarquia entre objetivos econômicos do governo, que subordinava as políticas macroeconômicas às necessidades da expansão interna, havendo ao mesmo tempo a passagem do predomínio de uma "ortodoxia" liberal às concepções e ideias econômicas mais heterodoxas, marcadas pela intervenção legítima do Estado para a promoção do desenvolvimento. É quando se definem mais claramente os elementos centrais do que futuramente viria a ser conhecido como "desenvolvimentismo". ${ }^{112}$ É justamente nessa dinâmica que se insere o debate acerca do Tratado.

\subsubsection{O pensamento político das elites brasileiras na década de 1930}

Edgard Carone aponta uma identidade ideológica persistente entre elites agrárias e urbano-industriais, corolário de sua identificação social: seriam ambas fortemente conservadoras. É a notável influência do pensamento europeu do século XIX, positivista, evolucionista, cientificista, que dá o tom da persistência de valores e do atraso das elites nacionais. Reagindo em uníssono contra qualquer ameaça concreta à ordem constituída, uma estrutura de poder brutalmente excludente, as frações da classe dominante impunham limites às reinvindicações de direitos sociais, por parte dos trabalhadores. Além disso, se articulavam numa ampla frente anticomunista. ${ }^{113}$

A ambiguidade é outra marca das elites brasileiras no período, oscilando entre um liberalismo contraditório e já bastante desgastado e uma concepção autoritária de política. Se se exaltava as virtudes da democracia, ao mesmo tempo se reivindicava um Estado forte para combater as ameaças à ordem, sejam externas ou internas. A posição autoritária vai num crescendo abarcando os diversos segmentos das elites, ainda quando estes ainda ostentassem um discurso liberal. ${ }^{114}$

O liberalismo das elites brasileiras já foi objeto de análises diversas e seu caráter predominantemente conservador e antidemocrático já foi devidamente ressaltado por

\footnotetext{
${ }^{111}$ Cf. Vários textos em: SIMONSEN, Roberto C. A Evolução industrial do Brasil e outros estudos. São Paulo: Cia. Ed. Nacional, 1975.

${ }^{112}$ Cf. BASTOS, Pedro P. Z. Ortodoxia e heterodoxia econômica antes e durante a Era Vargas. E vários outros artigos do livro: BASTOS, Pedro P. Z. e FONSECA, P. C. D. (orgs.) A Era Vargas: desenvolvimentismo, economia e sociedade. São Paulo: EDUNESP, 2012.

${ }^{113}$ CARONE, op. cit., p. 85. Ver também, acerca do anticomunismo das elites brasileiras: MOTTA, Rodrigo P. S. Em guarda contra o "perigo vermelho": O anticomunismo no Brasil (1917-1964). São Paulo: Perspectiva, 2002.

${ }^{114}$ CARONE, op. cit., p. 93.
} 
inúmeros autores. Maria Helena Capelato defende que o liberalismo esposado pelos representantes da imprensa paulista, no período estudado, era essencialmente uma ideologia de dominação social e contrarrevolucionária, sendo, portanto nesse sentido, também uma ideologia autoritária. ${ }^{115}$ Gradualmente, porém, o discurso liberal é contestado por concepções abertamente "autoritárias" acerca da melhor organização política para o Brasil.

Boris Fausto enfoca a ascensão de um "pensamento nacionalista autoritário", marcado pela desconfiança com relação às massas, tidas como "irracionais", uma tendência conservadora e tradicionalista, a repulsa ao individualismo, a crítica aos ideais políticos do liberalismo (tais como o federalismo e as eleições livres), a centralização e o reforço do poder do Estado e um forte nacionalismo. Dá ênfase às ideias de intelectuais como Alberto Torres, Azevedo Amaral, Oliveira Viana, Francisco Campos, entre outros, na elaboração desta tendência nacionalista e autoritária, que marcou as elites brasileiras da época. ${ }^{116}$

Para Bolívar Lamounier, formou-se na Primeira República o corpo de um pensamento político autoritário, que acaba se configurando em ideologia de Estado. Apesar da diferença entre os diversos intelectuais, para este autor o que se ressalta é a estrutura comum, baseada em críticas ao modelo constitucional da República, um mesmo modelo de narrativa, o ensaio histórico-sociológico e a aspiração de elevar o Estado ao elemento tutelar da sociedade. Para Lamounier, o período assistiu a uma inflexão ideológica, fazendo do anti-liberalismo o modelo dominante. ${ }^{117}$

Já José Beired, procurou delimitar alguns “campos" nos quais se inseriam estes intelectuais autoritários, marcando as diferenças entre um "polo cientificista", um "polo católico" e um "polo fascista". O primeiro deles, fundado no positivismo, teria sido o que congregou os intelectuais mais importantes para a formação de ideais que gradativamente viriam a nortear a elite do Estado. ${ }^{118}$

Ricardo Silva analisa a vertente do pensamento político brasileiro que denomina “ideologia do Estado autoritário", a qual caracteriza como irrealistas e fadadas ao

\footnotetext{
115 CAPELATO, Maria Helena Rolim. Os Arautos do Liberalismo: imprensa paulista 1920-1945. São Paulo: Brasiliense, 1988.

${ }^{116}$ FAUSTO, Boris. O pensamento nacionalista autoritário (1920-1940). Rio de Janeiro: Jorge Zahar, 2001.

117 LAMOUNIER, Bolivar. Formação de um pensamento político autoritário na primeira república: uma introdução. In: FAUSTO, B. (org.) Historia Geral da Civilização Brasileira. T. III, v. 2. Rio de Janeiro: Bertrand Brasil, 1997. p. 343-374.

${ }^{118}$ BEIRED, José L. B. Sob o signo da nova ordem: intelectuais autoritários no Brasil e na Argentina (19141945). São Paulo: Loyola, 1999, p. 17-68.
} 
fracasso as proposições de organização do Estado com base na soberania popular, devido à suposta incompatibilidade de tal princípio com as características da formação social brasileira. O argumento central dos citados intelectuais autoritários da década de 1930 é a tese de que a oposição entre o 'país legal' e o 'país real', ocasionada pela tentativa de se implantar um modelo constitucional anglo-saxônico, inadequado à realidade nacional, resultaria no "centrifuguismo da autoridade" e, consequentemente, na impossibilidade de se concretizar a organização nacional. ${ }^{119}$

A ideia de nação organizada se confunde aí com um Estado forte, com um Executivo hipertrofiado, para que se opusesse aos poderes regionais e ao legislativo e judiciário. Criticavam-se as constituições liberais e apontava-se como seus principais defeitos: o princípio federativo, concedendo autonomia aos estados e impedindo uma política orgânica, voltada aos interesses nacionais; o liberalismo político, que atribuía demasiada importância às Assembleias no processo decisório estatal, o que seria incompatível com as transformações socioeconômicas das sociedades modernas, cujas administrações exigiam decisões rápidas; e o modelo democrático, que permitiria que a irracionalidade política atribuída às massas fosse transferida às decisões estatais. ${ }^{120}$

Defendiam a legitimidade da estrutura de dominação do Estado autoritário que se verificaria na forma corporativa de organização e representação de interesses. As "classes relevantes" para a produção da riqueza se organizariam em cooperação com o Estado, sendo este amparado por métodos e técnicas da moderna ciência social, para formular políticas púbicas realistas e coerentes. Seria oferecida a segurança e proteção e a supressão da luta de classes, em troca da dócil submissão ao Estado. A representação corporativa se realizaria nos conselhos técnicos e pressuporia a organização em associações de classe. ${ }^{121}$

\footnotetext{
${ }^{119}$ SILVA, Ricardo. Ideologia de Estado e autoritarismo no Brasil. In: Cadernos de Pesquisa PPGSP/UFSC, n. 21, junho 2000.

${ }^{120}$ Idem, ibidem, p. 6.

${ }^{121}$ Idem, ibidem, p. 7.
} 


\section{Capítulo 3 - O Tratado Brasil-EUA de 1935: História e Historiografia}

\subsection{História - O Tratado no contexto: Crise e oportunidades}

A conjuntura internacional, na primeira metade da década de 1930, foi marcada pela turbulência da crise e da Grande Depressão. Verificou-se então forte contração da liquidez no mercado mundial e uma notável diminuição dos fluxos comerciais e financeiros. A crise também alterou o próprio arcabouço da economia mundial. Países antes dominantes, como a Inglaterra, experimentaram um declínio relativo, enquanto outros, como a Alemanha que se recuperava de uma grave crise no pós-Guerra, começavam a despontar como importantes atores do comércio mundial. ${ }^{122}$

A Alemanha, em particular, passou a disputar mercados, antes pouco atingidos por suas exportações, buscando a obtenção de acordos bilaterais de comércio compensado. ${ }^{123}$ Esta política foi contraposta veementemente pelos esforços da política externa dos EUA, os quais, nesse contexto, procuraram obter a assinatura de acordos com o Brasil e vários outros países, pautados na cláusula de nação mais favorecida, ${ }^{124}$ a fim de assegurar sua predominância econômica e política nesses mercados, considerados estratégicos.

As Figuras 1 e 2, a seguir, ilustram graficamente a evolução da importância da Alemanha no comércio - tanto de exportação quanto de importação - com o Brasil. Importante notar como este país chegará, em meados da década de 1930 a se tornar o

\footnotetext{
122 Para uma apreciação mais abrangente de questões relativas à inserção internacional do Brasil no período, ver: ABREU, Marcelo de Paiva. O Brasil e a Economia Mundial, 1930-1945: políticas econômicas externas e relações econômicas internacionais. Rio de Janeiro: Civilização Brasileira, 1999. BARRETO, Fernando P. de Mello. Os sucessores do Barão: relações exteriores do Brasil, 1912-1964. São Paulo: Paz e Terra, 2001. p. 87-164; CERVO, Amado Luiz e BUENO, Clodoaldo. História da política exterior do Brasil. Brasília: UNB, 2001. p. 253-258; GAMBINI, Roberto. O duplo jogo de Getúlio Vargas: influência americana e alemã no Estado Novo. São Paulo: Ed. Símbolo, 1977. HILTON, Stanley. O Brasil e as Grandes Potências: os aspectos políticos da rivalidade comercial, 1930-1939. Rio de Janeiro: Civilização Brasileira, 1977 e MOURA, Gerson. Autonomia na Dependência: A política externa brasileira de 1930-1942. Rio de Janeiro: Nova Fronteira, 1980.

${ }^{123}$ O comércio de compensação se caracteriza pela supressão da utilização de divisas nas relações comerciais. Cria-se em ambos os países envolvidos "caixas de compensação". Os importadores de um país, ao comprarem do outro, transferem suas dívidas para esta "caixa", em moeda de seu país. Os exportadores, por sua vez, ao venderem, são pagos em moeda nacional pela caixa de seu país. Como se pode perceber é uma modalidade de comércio que tende a vincular os parceiros em trocas bilaterais.

${ }^{124}$ Cláusula comum aos tratados comerciais de cunho liberalizante, estabelece que cada país signatário deve dispensar ao outro tratamento não menos favorável do que aquele reservado aos produtos de qualquer outro país com que mantenha relações comerciais, independentemente de ter ou vir a ter outros tratados vigentes com outra nação. Tende a promover as trocas num sentido multilateral.
} 
segundo maior parceiro comercial do Brasil. Crescimento que se fez em detrimento, principalmente, da participação britânica no mercado brasileiro.

Tratava-se, para além desse quadro mais geral, de um momento crítico para a economia brasileira. A crise econômica mundial e a Grande Depressão que a seguiu na década de 1930 coincidiram ainda com uma crise da economia cafeeira, patente desde a década anterior. O choque externo sobre a economia brasileira afetou o balanço de pagamentos principalmente através da brutal queda dos preços de exportação, não compensada por aumento do quantum exportado, e da interrupção do influxo de capitais estrangeiros. Houve então substancial declínio da renda nacional, ainda que relativamente atenuado pelos efeitos das políticas de defesa do setor cafeeiro e pelo desempenho favorável da emergente indústria nacional. ${ }^{125}$

Tal desarranjo econômico ocorreu em paralelo com mudanças políticas importantes, que não se restringiram ao Brasil, sendo antes fenômenos mais gerais. Aqui, a Revolução de 1930 abriu novas possibilidades de mudanças ao deslocar a oligarquia cafeeira da posição hegemônica e ao constituir um arranjo político no qual nenhum setor dominante tinha condições imediatas de firmar sua proeminência. Os anos iniciais da década de 1930 foram de grande instabilidade, com diferentes projetos em luta pela condução da política econômica nacional. ${ }^{126}$

Esses diferentes projetos se refletiam na formulação da política externa, que incorporou elementos de nacionalismo e de abertura externa, que não necessariamente entram em contradição. Se a política externa de Vargas, em linhas gerais, se estruturou com base na ideia de construir um capitalismo nacional autônomo, sobretudo a partir do Estado Novo, esta ideia de autonomia não excluía certo grau de abertura aos fluxos de comércio e investimento estrangeiro, na medida em que contribuíssem para o fortalecimento do capitalismo nacional. ${ }^{127}$

Foi no quadro histórico acima esboçado que os Estados Unidos tomaram a iniciativa de iniciar, em 1933, as negociações para a assinatura de um tratado bilateral de comércio com o Brasil, fundamentado na cláusula de nação mais favorecida. As concessões do lado brasileiro incluíam a redução da tributação sobre uma extensa lista de

\footnotetext{
${ }^{125}$ Cf. FURTADO, op. cit., principalmente os capítulos XXXI e XXXII, p. 186-203.

${ }^{126}$ CORSI, Francisco L. Brasil e Argentina: uma análise das políticas econômicas do período 1930-1945. In: Revista de Economia Política e História Econômica, número 05, julho de 2006. p. 46-47.

${ }^{127}$ CORSI, Francisco Luiz. Estado Novo: política externa e projeto nacional. São Paulo: UNESP, 2003.
} 


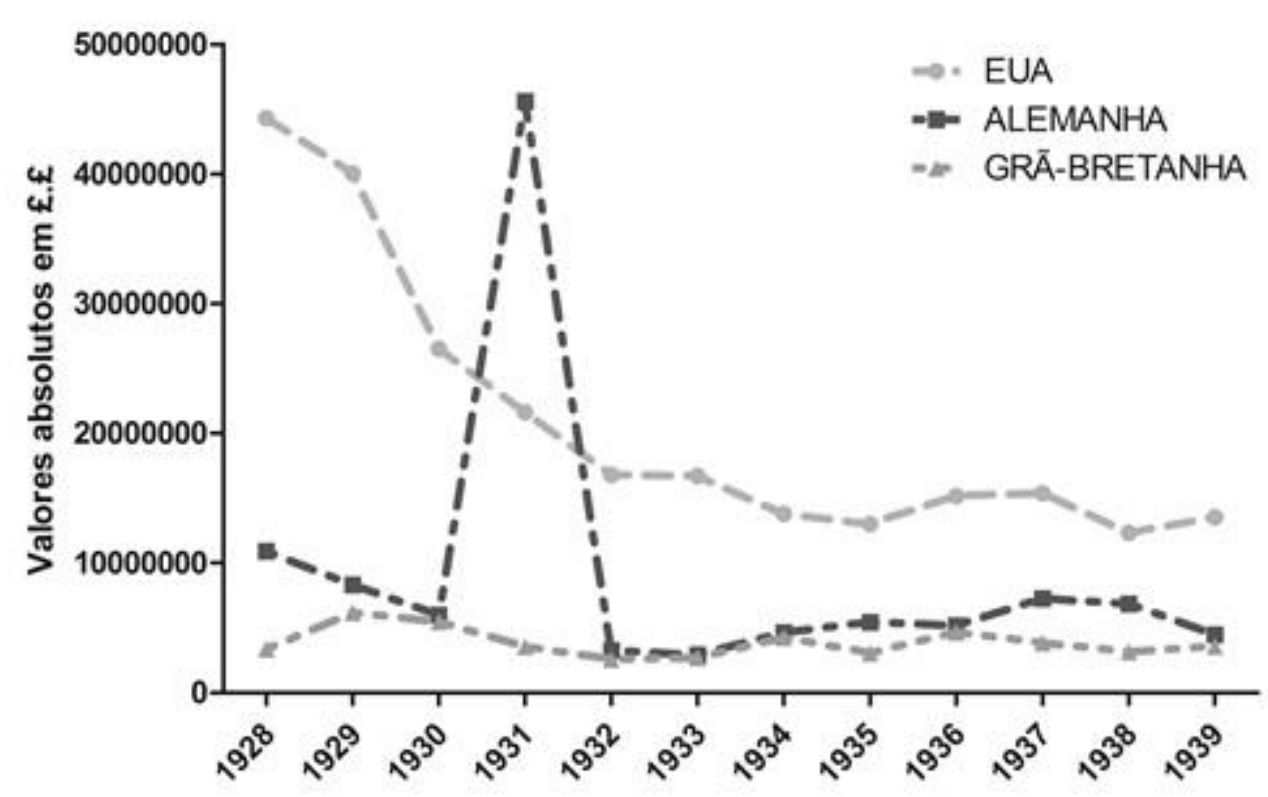

Figura 2.1 - Valores totais de importação de mercadorias pelo Brasil, procedentes dos EUA, Alemanha e Grã-Bretanha, no período 1928-1939.

Fonte: IBGE. Anuário Estatístico do Brasil, 1939-1940, p. 1366-1369.

Notas: * Valores absolutos, em libras-ouro (1939).

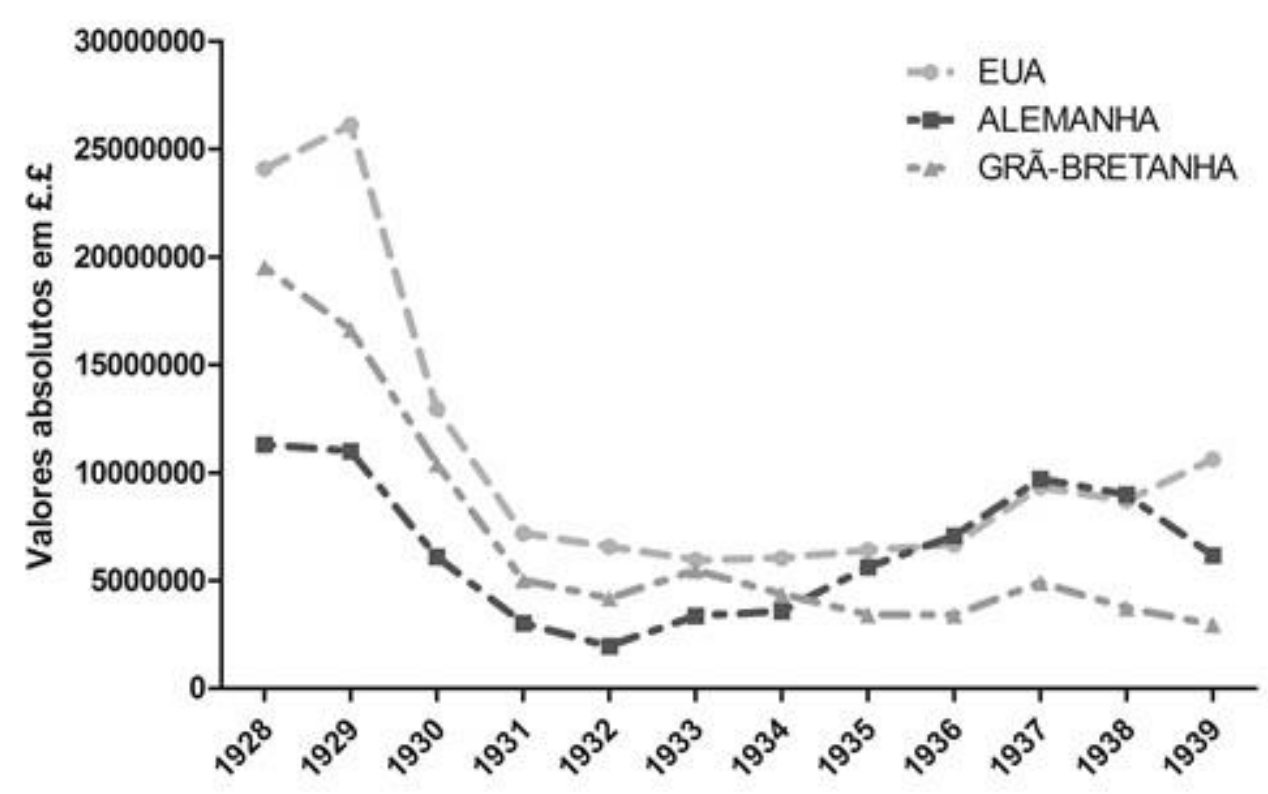

Figura 2.2. - Valores totais de exportação de mercadorias do Brasil, destinadas aos EUA, Alemanha e Grã-Bretanha, no período 1928-1939.

Fonte: IBGE. Anuário Estatístico do Brasil, 1939-1940, p. 1366-1369.

Notas: * Valores absolutos, em libras-ouro (1939). 
produtos, entre os quais bens de consumo duráveis. Já os Estados Unidos se comprometiam a manter o café na lista de produtos isentos de tributação, além de conceder reduções tarifárias para alguns artigos, em sua maioria bens primários.

O governo brasileiro inicialmente não demonstrou grande interesse na assinatura do tratado, mas acabou cedendo às pressões norte-americanas. O Departamento de Estado dos EUA utilizou ameaças de imposição de controle unilateral do intercambio com o Brasil e de taxação sobre o café para extrair as concessões pretendidas. ${ }^{128} \mathrm{O}$ acordo foi negociado em sigilo, pelo representante plenipotenciário do Brasil em Washington, o embaixador Osvaldo Aranha e o secretário de estado norte-americano Cordel Hull, e foi assinado em dois de fevereiro de 1935.

De acordo com a Constituição Federal de 1934 recém-promulgada, uma vez assinado, o Tratado teria que ser ratificado pelo Congresso Nacional para entrar em vigor. Sob a pressão do Departamento de Estado dos EUA para que fosse rapidamente aprovado, o Tratado teve então que ser revelado publicamente. $\mathrm{O}$ encaminhamento parlamentar para a ratificação acabou por suscitar um amplo e acalorado debate público, na imprensa, na Câmara dos Deputados, nas associações de classe e até no seio do Estado e seus órgãos.

O debate em questão contrapôs os defensores da liberalização do comércio e os defensores de políticas de caráter protecionista e assistiu à articulação de grupos de interesse, que se posicionaram em função de objetivos "de classe", ou de outra ordem, definidos com maior clareza no decurso do próprio debate. Propiciou também a formulação e apresentação pública de projetos nacionais divergentes e antagônicos. Após longo impasse, foi necessária a atuação direta do próprio Getúlio Vargas para que a ratificação do Tratado fosse efetivada, em 24 de dezembro de 1935.

Após sua aprovação, o Tratado entrou finalmente em vigor. As principais interpretações historiográficas que dele se ocupam parecem apontar para o fato de que, uma vez efetivado, o acordo não produziu os efeitos econômicos esperados. Tal fato se deveria a fatores diversos, entre os quais as constantes depreciações cambiais, a inelasticidade do mercado cafeeiro e o acordo comercial informal efetivado no ano seguinte com a Alemanha, baseado no comércio compensado. ${ }^{129}$

\footnotetext{
${ }^{128}$ Cf. ABREU, 1990, op. cit., p. 74.

129 “(...) esse tratado não produziu os resultados que se esperavam no momento de sua assinatura. 0 mercado norte-americano de café apresentava pouca elasticidade, e o Brasil não dispunha de caixa
} 
No presente estudo, o nosso foco de análise não é o Tratado em si, e sim os debates que cercaram a sua assinatura, bem como a sua ratificação no legislativo, pelo que revelam acerca de problemas históricos de importância fundamental. Serão estes debates, portanto, o objeto específico de nossa investigação.

\subsection{O Tratado e a Historiografia: Indústria versus agroexportação?}

A literatura que lida diretamente com o Tratado de 1935 é constituída por obras propriamente historiográficas, mas também por estudos na área de Ciência Política e Relações Internacionais. Obras clássicas como as de Stanley Hilton ${ }^{130}$ e John D. Wirth ${ }^{131}$ procuram situar o tratado com relação ao conjunto da política externa do Brasil no período, inserindo-a num contexto de competição internacional por mercados e influência geopolítica entre Estados Unidos e Alemanha e de formulação de políticas nacionais que objetivavam enfrentar a crise mundial.

Hilton procura compreender as decisões dos agentes encarregados de formular a política externa oficial do Estado brasileiro - os chamados policy makers -, frente ao conflito entre o bilateralismo alemão e o liberalismo norte-americano, enfocando os interesses comerciais de ambos os países no mercado brasileiro e sua influência na política nacional e externa do Brasil. Parte de uma abordagem metodológica de caráter individualista, que se atém principalmente às concepções de uma determinada elite ligada à política externa, por entender que a sua visão da realidade internacional determinaria suas decisões e estas, por sua vez, determinariam os rumos da política externa nacional.

Uma interessante análise das percepções sobre a crise aponta para as visões de instabilidade econômica, fragilidade da paz e um clima geral de "guerra econômica", no qual reinava a lógica da força como determinante da política externa. ${ }^{132}$ Porém, a sua contribuição mais significativa foi a ideia de que, frente à competição aberta entre as duas grandes potências, os tomadores de decisão do governo brasileiro puderam contar com uma margem de manobra significativamente maior do que a que tinham anteriormente, para a definição de uma nova inserção do Brasil na economia mundial, visando um

suficiente para importar muito mais do que já importava dos Estados Unidos. A nascente indústria brasileira não registrou abalo nas dimensões que se anunciavam." In: CERVO, e BUENO, 2002, op. cit., p. 254-255. No mesmo sentido se manifesta ABREU, op. cit., bem como a maioria dos demais autores aqui tratados.

${ }^{130}$ Cf. HILTON, op. cit.

${ }^{131}$ WIRTH, John D. A política do desenvolvimento na era de Vargas. Rio de Janeiro: FGV, 1973.

${ }^{132}$ HILTON, op. cit., p. 35. 
projeto de desenvolvimento industrial. Tal tese tornou-se muito influente e veio a ser adotada por inúmeras interpretações acerca do período, conforme veremos, porém, a ênfase nos indivíduos e na tomada de decisões individuais não permitiu a esse autor desenvolver melhor a questão de fundo, mais ampla, relativa aos interesses (de classe ou outros) então em jogo.

Desenvolvendo esta tese ainda mais, Wirth afirma que o Brasil de Vargas se prestou a um "jogo de ambiguidades", entre 1934 e 1940, o qual teria permitido que estabelecesse relações comerciais com todos os interessados, ao mesmo tempo evitando o problema implícito do alinhamento político, com um objetivo industrialista. Contudo, para o autor, o governo não conseguiu elaborar uma estratégia de longo alcance, nem soube explorar a fundo seu poder de barganha a fim de obter bens necessários ao desenvolvimento. ${ }^{133}$

Segundo Wirth, tal indefinição teria se devido em parte ao fato de que "Vargas não desejava sacrificar nenhum dos grupos exportadores regionais, muitos dos quais se vinculavam ao comércio alemão ou ao norte-americano" 134 e que "o caráter difuso do programa de ação espelhava as discordâncias internas dentro dos ministérios e entre os principais conselheiros com relação aos objetivos". Resultou desse quadro uma ênfase na exportação de café e algodão, a qual poderia obter mais amplo apoio. ${ }^{135}$

Ainda Hilton fez alguns apontamentos relevantes para o presente estudo, ao indicar as divisões internas ao próprio governo brasileiro quanto ao Tratado. Se, de um lado, o Embaixador em Washington e principal negociador brasileiro, Osvaldo Aranha sempre estivera mais inclinado a uma aproximação com os EUA e Valentim Bouças, diretor da seção técnica do CFCE, era abertamente pró-americano, o que transpareceu em seu apoio ao Tratado e a uma política de comércio de tipo liberal; de outro, Sebastião Sampaio, chefe da seção comercial e econômica do MRE e Marcos de Souza Dantas, diretor da carteira de cambio do Banco do Brasil, eram favoráveis a uma aproximação com a Alemanha e aos acordos de comércio compensado. ${ }^{136}$

A fim de fazer uma apresentação das principais interpretações sobre o Tratado, que tratam de questões mais pertinentes para uma análise que leve em conta elementos de

\footnotetext{
${ }^{133}$ WIRTH, op. cit., p. 3-4.

${ }^{134}$ Idem, Ibidem, p. 4.

${ }^{135}$ Idem, Ibidem, p. 5.

${ }^{136}$ HILTON, op. cit. p. 79-123.
} 
economia política, ideias e grupos de interesse, os quais possuem relevância fundamental para a abordagem que adotamos, tomamos como ponto de partida o artigo original de Maria Celina S. D’Araújo e Gerson Moura, o qual é citado como referência central por várias das obras que tratam do episódio. Partindo também da documentação sobre o debate parlamentar, o enfoque explícito de sua análise é a atuação do empresariado industrial, identificada como frontalmente contrária ao Tratado, a partir dos discursos de alguns de seus líderes reconhecidos, como Euvaldo Lodi e Roberto Simonsen. ${ }^{137}$

A tese central defendida pelos autores é a de que o Tratado teria servido como “(...) um instrumento para se denunciarem as arbitrariedades do governo e o controle excessivo de Vargas sobre as informações e deliberações que eram tomadas". ${ }^{138}$ Além disso, teria sido um episódio que caracterizou a articulação política dos industriais em torno de seus interesses de classe específicos, agregados a posições nacionalistas. No mesmo sentido, para Leopoldi, o Tratado teria visado essencialmente os interesses do café. Contudo, tal "derrota de curto prazo" dos interesses da indústria teria servido para consolidar as posições dos líderes industriais no Congresso, amadurecendo seu discurso, seu envolvimento com o comércio exterior e melhor articulando seu "nacionalismo". ${ }^{139}$

Já para Gerson Moura, o Tratado de 1935 aparece como um dos acontecimentos que puseram em teste o princípio da "equidistância pragmática" na condução da política externa do Brasil. ${ }^{140}$ A oposição de interesses internos (lavoura e comércio agroexportador de um lado, versus os industriais de outro) e externos (EUA e Alemanha) aqui se traduziu em dois grupos fundamentais de políticas comerciais, o chamado "comércio protegido" e o "livre comércio", que se tornaram polos de uma polêmica geral. ${ }^{141}$ Para ele, a maior parte dos mentores da política econômica federal, bem como os defensores da economia agroexportadora, tinha um pensamento liberal clássico.

Cervo e Bueno, por sua vez, afirmam que o Tratado de 1935 representou um momento no qual:

\footnotetext{
${ }^{137}$ D'ARAÚJO, Maria Celina e MOURA, Gerson. O tratado comercial Brasil-EUA de 1935 e os interesses industriais \brasileiros. In: Revista de Ciência Política, Rio de Janeiro, v. 21, n. 1, p. 55-73, jan./mar. 1978.

${ }^{138}$ Idem, ibidem, p. 70.

139 LEOPOLDI, Maria Antonieta P. Política e Interesses na Industrialização Brasileira: as associações industriais, a política econômica e o Estado. São Paulo: Paz e Terra, 2000, p. 93-152.

${ }^{140}$ Tal princípio, que para Moura orientou a política externa de Vargas, é definido como o aproveitamento deliberado da conjuntura de indefinição do poder global, bem como de uma "ameaça" de aproximação política e econômica mais estreita com a Alemanha, para a obtenção de vantagens e de uma maior autonomia relativa frente aos EUA, ainda que nos limites ditados pela dependência. Cf. MOURA, op. cit.

${ }^{141}$ MOURA, op. cit., p. 69.
} 
(...) a discussão a respeito do caminho para o desenvolvimento nacional foi acesa. Os seus opositores viam o tratado como prejudicial à indústria brasileira; os favoráveis entendiam que o café deveria ser protegido, pois sustentava o Brasil, e não a industrialização incipiente, carente de favores do Estado. ${ }^{142}$

Segundo os autores citados acima, o acordo, em termos dos interesses aos quais atendia, "contemplava principalmente o café de um lado e as exportações norteamericanas de outro". ${ }^{143}$

Roberto Gambini reforça a tese de que o Tratado teria atendido exclusivamente aos interesses dos produtores e comerciantes de café, em detrimento dos industriais. Nesse sentido, relata como o Departamento de Estado norte-americano, na tentativa de convencer as autoridades brasileiras quanto às vantagens do acordo, teria se valido de argumentos que concerniam exclusivamente aos interesses da cafeicultura brasileira, sem referir-se uma única vez à indústria.

Segundo o autor, isto se devia ao fato de que "o prejuízo desta [a indústria] era a contrapartida necessária para o lucro das indústrias americanas e dos exportadores de café", sendo este um momento em que "os interesses do setor cafeeiro e dos Estados Unidos são interpretados como complementares (...), com o que a perspectiva industrial era posta de lado". Para este autor, o próprio acordo teria servido como fonte geradora de antagonismo e animosidade entre os setores da elite brasileira, tendo em vista que prejudicava a indústria e "fortalecia a posição do setor exportador". ${ }^{144}$

Ainda, segundo Gambini, os agentes do governo brasileiro teriam sido guiados, nas negociações prévias à assinatura do Tratado, por considerações associadas tanto aos interesses do complexo exportador, quanto à arrecadação fiscal. De fato, para o autor, todos os esforços do Estado brasileiro nas negociações em 1934, marcado pela postergação de sua conclusão, visavam exclusivamente à manutenção das tarifas e das receitas delas advindas, sem qualquer preocupação em defender a indústria nacional. Além disso, a ação do Estado estaria bastante alinhada aos interesses da cafeicultura, considerados primordiais.

Quanto à atuação dos industriais no debate parlamentar, a tese de Gambini é a de que seu empenho em obstruir a ratificação do Tratado, bem como a incapacidade de

\footnotetext{
${ }^{142}$ CERVO e BUENO, op. cit., p. 254-255.

${ }^{143}$ Idem, Ibidem.

${ }^{144}$ GAMBINI, 1977, op. cit. p. 96-101.
} 
rejeitá-lo como um todo, reivindicando apenas a substituição de certos itens e tarifas, seria reveladora da fraqueza da posição política daquela classe, naquelas circunstâncias. Tal fraqueza teria sido percebida - e explorada - pelo departamento de Estado estadunidense, o que poderia ser verificado pela sua indisposição em rever qualquer cláusula do Tratado após a análise das comissões parlamentares. ${ }^{145}$

$\mathrm{Na}$ análise de Marcelo de Paiva Abreu, ${ }^{146}$ o foco se desloca do debate interno para os determinantes da política externa e os meandros das negociações que ocorreram nos Estados Unidos, entre os representantes diplomáticos do Itamaraty e do Departamento de Estado norte-americano. Talvez a sua maior contribuição ao presente estudo seja a análise da força relativa dos negociantes e a contraposição à ideia de que o governo brasileiro teria operado com significativa margem de manobra, ressaltando ao contrário a assimetria de forças e a capacidade de imposição por parte dos Estados Unidos no episódio estudado. $^{147}$

Ao passar, ainda que brevemente, ao debate brasileiro (do qual ora nos ocupamos), o autor delineia os grupos dele participantes. Para Abreu, os dois lados em disputa no debate sobre o tratado podem ser assim compreendidos:

"De um lado [contrários ao Tratado], os industriais paulistas, liderados por Roberto Simonsen (...). Do outro lado, alinhavam-se, liderados por Valentim Bouças, os defensores da aproximação do Brasil com os estados Unidos, favoráveis, portanto, a quaisquer medidas tendentes à liberalização". ${ }^{148}$

Ou seja, para Abreu, trata-se antes de uma questão que importava a interesses do comercio de exportação, aliada a uma questão de política externa: tratava-se de buscar a manutenção das relações cordiais com os Estados Unidos, sendo que os elementos próamericanos próximos ou pertencentes ao governo brasileiro, tais como Valentim Bouças e Osvaldo Aranha teriam atuado como seus principais defensores.

\footnotetext{
${ }^{145}$ Idem, Ibidem, p. 7.

${ }^{146}$ ABREU, Marcelo de Paiva. Crise, crescimento e modernização autoritária: 1930-1945. In: ABREU, M. P. (org.). A ordem do progresso: cem anos de política econômica republicana, 1889-1989. Rio de Janeiro: Campus, 1990. p. 86-9, bem como ABREU, 1999, op. cit..

${ }^{147}$ Cf. ABREU, 1999, op. cit. e ABREU, M.P. La Argentina y Brasil en los años treinta: efectos de la política económica internacional británica y estadounidense. In: Desarrollo Económico, v. 24, n. 96, jan-mar, 1985, p. 543-559.

${ }^{148}$ ABREU, 1990, op. cit., p. 87.
} 
Finalmente, ao discorrer sobre as relações entre as decisões tomadas quanto ao Tratado e os interesses dos grupos e de setores da economia nacional, Abreu afirma que “a política econômica externa brasileira foi definida à luz dos interesses de diferentes setores da sociedade, os quais, no caso em tela, não eram conflitantes". ${ }^{149}$ E, decerto, nos parece que essa coincidência de interesses mais gerais entre setores das classes capitalistas brasileiras no período, se verifica efetivamente, principalmente ao notarmos o empenho dos próprios industriais em apoiar a economia exportadora, e em particular o café, tendo em vista a sua importância reconhecida para a economia nacional.

Contudo, também parece claro que houve divergências e polarizações efetivas acerca do Tratado, que de certa forma se relacionam com interesses de frações de classe específicas. Ao menos é o que se pode depreender da participação dos líderes industriais no episódio. Portanto, em nosso entendimento, permanece em aberto a questão de até que ponto seriam esses interesses dos diversos setores sociais realmente coincidentes, com relação ao que estava em jogo na aprovação do Tratado?

Pedro C. Dutra Fonseca vê assinatura do Tratado de 1935 como um exemplo do apoio governamental dado à indústria, no sentido de favorecer a importação de bens de capital. Este autor reconhece o fato de que "alguns líderes industriais tenham se mostrado críticos ao tratado, pois este também permitia a importação de certos bens de consumo". ${ }^{150}$ Contudo, para Fonseca, o Tratado "não deixa de demonstrar a intenção governamental de romper com o antigo papel de importador destes bens, ao incluir os bens de capital intermediários necessários à indústria". 151

Para Fonseca, enquanto os industriais já estabelecidos teriam preferido incentivos para a utilização da capacidade existente, ao invés de um aumento na importação de equipamentos, que poderia facilitar a entrada de novos concorrentes, o comportamento do governo seria uma mostra do "interesse em modificar a pauta de importações, aprofundando o crescimento industrial e em coerência com o modelo substitutivo, ou seja, mudando-a, qualitativamente, através da perda da posição relativa dos bens de consumo frente à elevação dos bens de capital, intermediários e insumos industriais". ${ }^{152}$

\footnotetext{
${ }^{149}$ ABREU, 1990, op. cit., p.89.

${ }^{150}$ FONSECA, op. cit., p. 141.

${ }^{151}$ Idem, Ibidem, p. 141.

152 Idem, Ibidem.
} 
Porém, fica claro que a assinatura do acordo desagradou aos representantes industriais, que não viram nela qualquer vantagem. Também não parece que o acordo tenha favorecido a importação de insumos e equipamentos, nem que tenha favorecido a indústria local, pois na lista de produtos contemplados, verifica-se que a vasta maioria dos produtos norte-americanos que obtiveram redução tarifária eram de fato bens de consumo acabados. ${ }^{153}$

A celebração do Tratado, para Mariza S. Leme, representou um momento no qual o Estado realizou o inverso do que era então preconizado pelos industriais e notavelmente por Roberto Simonsen. ${ }^{154}$ Já nesse momento, os líderes do setor haviam elaborado um conjunto de diretrizes gerais para a política externa e principalmente para o comércio exterior. Tratava-se de buscar a superação do atraso econômico e da dependência financeira com relação aos "países ricos", através da busca da evolução e racionalização da produção agrícola e a proteção e desenvolvimento dos mercados internos para a indústria.

Para Leme, as considerações críticas feitas por Simonsen ao tratado, durante e após o debate (a inexistência de uma definição clara de política comercial, a adoção indiscriminada da cláusula de nação mais favorecida, etc.), não teria levado em conta os interesses dos "grupos econômicos brasileiros que se beneficiaram com ele", tendo considerado apenas o que teria sido possível ao governo realizar, caso tivesse em mente o programa de desenvolvimento dos industriais. Ainda prossegue: "O fato é que, na realidade, o governo de Vargas defende até o fim os termos em que o acordo foi elaborado, e recebe pleno apoio da lavoura. Os únicos a protestarem contra (...) são os empresários industriais". ${ }^{155}$

Como veremos mais adiante, esta apreciação sobre o Tratado não se sustenta frente às evidências documentais, não ao menos sem a devida qualificação. Trata-se mais uma vez da consolidada tese de que a lavoura e o comércio (ou a "agroexportação", termos aqui intercambiáveis) teriam sido ativos defensores do Tratado, participando do debate em seu favor, o que não se verifica na documentação estudada.

Decerto, o governo o defendeu com "unhas e dentes" até o fim e é este fato em particular que nos interessará para o presente estudo. Mas, conforme será demonstrado mais adiante, os representantes de interesses que poderiam ser relacionados às frações

\footnotetext{
${ }^{153}$ Cf. Apêndice do Decreto N. 542, de 24 de dezembro de 1935.

${ }^{154}$ LEME, op. cit., p. 296.

${ }^{155}$ Idem, Ibidem. p. 297-8.
} 
agrária e comercial da burguesia, sejam os deputados classistas na Câmara, ou as suas associações de classe, não se apresentaram para o debate. Ficou, de fato, a cargo de representantes do Estado, em geral ligados à burocracia estatal, a defesa do Tratado. E será esse nosso ponto de partida.

Para Leopoldi, o Tratado de 1935 deve ser entendido como parte do "jogo de forças" que caracterizou o novo regime político de Vargas, que então se consolidava. Se colocadas uma em face da outra, a Reforma Tarifária de 1934, de caráter protecionista, e a assinatura do Tratado, ambas representariam duas políticas contraditórias, que demonstrariam a disposição do governo em "conciliar os interesses básicos para a economia do país: a exportação do café e o desenvolvimento industrial", demonstrando assim que os objetivos do governo "não eram de todo complementares". 156

Nesse sentido, o Tratado teria sido rejeitado pelos representantes dos industriais na Câmara, em função de ter marcada orientação livre-cambista e pelo fato de fazer concessões a produtos manufaturados a serem importados dos Estados Unidos. O governo, por sua vez, ao adotar uma política de dualidade com relação à indústria e uma política comercial ambivalente - uma vez que se preparava já então para a assinatura de um tratado de comércio compensado com a Alemanha -, demonstrava esforço de conciliação de demandas antagônicas dos vários setores econômicos que lhe davam suporte. E, para a autora, o Tratado aparece como exemplo de medida que visava atender aos interesses desses "outros setores econômicos (em especial cafeicultores e exportadores)". 157

Para Leopoldi, ainda o fracasso da tentativa dos líderes industriais de bloquear sua ratificação no Congresso, frente à intervenção pessoal direta do próprio Vargas, seria evidência de que se tratava de "momento ainda de afirmação política dos industriais como classe dotada de identidade própria". Isto denotaria um contexto no qual ainda não seria uma classe dotada de força política e coesão social e ideológica, para que tivesse maior peso na determinação dos rumos da política econômica, preferindo os seus líderes não sofrer desgastes em sua relação com o governo. ${ }^{158}$

Ao longo do presente estudo, procuramos formular a questão de forma mais precisa, como parte dos problemas que orientaram a pesquisa: como o debate acerca do

\footnotetext{
${ }^{156}$ LEOPOLDI, op. cit., p. 124.

${ }^{157}$ Idem, Ibidem, p. 127.

${ }^{158}$ LEOPOLDI, op. cit., p. 125.
} 
Tratado poderia nos ajudar a compreender o processo de formação de um consenso em torno da necessidade de um desenvolvimento industrial?

Todas as questões aqui abordadas nos remetem a toda uma problemática rica e complexa. Daí, portanto, considerarmos o episódio como digno de uma investigação histórica focada não no Tratado em si - o qual acabou tendo poucos efeitos concretos na economia e na dinâmica das relações comerciais do Brasil -, mas nos elementos de processos históricos mais amplos, cuja dinâmica, naquele contexto específico, torna-se mais visível a partir de sua análise. Entre tais processos, figuram o da formação de um pensamento industrial mais coeso e de um projeto político-econômico desenvolvimentista baseado na indústria e o da reconfiguração político-ideológica do Estado brasileiro e de seu papel histórico. 


\section{CAPÍTULO 4 - Problemas e Hipóteses de Trabalho}

Partindo das considerações, acima feitas, acerca da historiografia sobre o Tratado de 1935, e após um confronto inicial com a documentação reunida para o presente estudo, algumas questões surgiram para fundamentar nossa análise. Num primeiro momento, no estudo do debate parlamentar, foi constatado que quase não houve a participação direta de representantes classistas da lavoura e pecuária no debate. Também pequena relativamente foi a participação de figuras mais diretamente ligadas ao comércio exportador - ressalta-se, como exceção, a participação de Valentim Bouças. Ao invés disso, os defensores mais ativos do tratado puderam ser identificados como membros da burocracia estatal e de uma elite burocrática, ${ }^{159}$ notavelmente funcionários públicos de carreira e membros da estrutura do governo.

Tais constatações nos sugeriram a formulação de um problema inicial: Qual foi concretamente a conformação dos grupos que se opuseram no debate, particularmente o dos defensores do Tratado? A partir dele, surgiram as ainda as seguintes questões correlatas, que passaram a orientar nossa pesquisa:

1) Os participantes do debate podem ser considerados representantes diretos de classes ou frações de classe específicas?

2) É possível identificar o caráter de algumas das ideias defendidas?

3) Como tais ideias foram apropriadas e como foram instrumentalizadas na defesa de determinadas posições frente ao que se percebia estar em jogo a partir da aprovação do Tratado no Congresso?

Assim, propusemos uma hipótese interpretativa para qualificar as visões tradicionais:

A defesa do tratado foi feita por membros da burocracia estatal e da elite política, em nome de uma ideologia particular, afinada em vários aspectos com os interesses das elites agrárias, mas não necessariamente diretamente motivada pela defesa destes.

\footnotetext{
${ }^{159} \mathrm{O}$ emprego de tal conceito, bem como suas implicações teóricas, foi explorado na seção que trata dos referenciais teóricos da presente dissertação.
} 
Um segundo problema que então formulamos, a partir do mapeamento dos grupos participantes, seria o de verificar o seguinte:

Quais eram - e se é possível identificá-los claramente - alguns dos projetos políticos, relativos às políticas externa e econômica defendidos publicamente pelos diferentes grupos que se posicionaram no debate acerca do Tratado? Tal problema será abordado nos últimos capítulos da presente dissertação, a partir das análises de uma documentação mais ampla.

A hipótese que aqui postulamos é a seguinte:

No caso do tratado, os industriais, no papel de intelectuais orgânicos de uma fração particular da burguesia, estariam em processo de formulação de um projeto hegemônico que une elementos de um "projeto restrito" e de um "projeto global". ${ }^{160}$ Teria se tratado assim de um projeto de inserção na economia mundial que passava por um questionamento da concepção tradicional do Brasil como produtor de produtos primários para o mercado externo e consumidor de mercadorias manufaturadas importados, incorporando, em paralelo a essa forma de inserção, a função de produtor industrial para o mercado interno, num primeiro plano e, num segundo a de exportador de manufaturados.

A viabilidade para a formulação de tais projetos, naquela conjuntura específica, era condicionada em parte pela crise da hegemonia das frações ligadas à agroexportação e se expressou concretamente nos conflitos entre as diversas frações do capital. Parece-nos que era de fato mais viável o projeto restrito, uma vez que, devido ao modo particular de inserção do Brasil na economia mundial e da estrutura da economia nacional, os interesses da fração agroexportadora não poderiam ser simplesmente subsumidos aos interesses da fração industrial, ou seja, a construção de um conjunto de representações tendentes a forjar um consenso hegemônico em torno da ideia de um Brasil industrial não pode então subsistir, dando lugar à identidade híbrida da economia nacional e de sua inserção na economia mundial.

\footnotetext{
${ }^{160}$ Os conceitos de "projeto hegemônico restrito e global" são extraídos de BIANCHI, Álvaro. Empresários e ação coletiva: notas para um enfoque relacional do associativismo. In: Revista Sociologia Política. Curitiba, 28, jun/2007a. p. 117-129 e foram explicitados na seção que trata dos referenciais teóricos da presente dissertação.
} 
Em parte, isso se deveria também ao fato de que, como descreveu Diniz, a diferenciação entre as referidas frações de classe não se encontrava plenamente constituída. Apesar de verificarmos nesse episódio um exemplo concreto de como, numa conjuntura específica, e com a finalidade de tratar de questões específicas, tal diferenciação pode se processar, tanto no plano do discurso como na prática política. Mas esta era ainda um processo, assim como era um processo a construção da hegemonia de um projeto industrialista, que se consubstanciaria, em um período subsequente, sob a plena vigência do chamado "ciclo ideológico do desenvolvimentismo". ${ }^{161}$

${ }^{161}$ Aqui nos referimos à formulação de BIELSCHOWSKY, Ricardo. Pensamento econômico brasileiro: 1930 1964 O ciclo ideológico do desenvolvimentismo. Rio de Janeiro: Contraponto, 2001. 


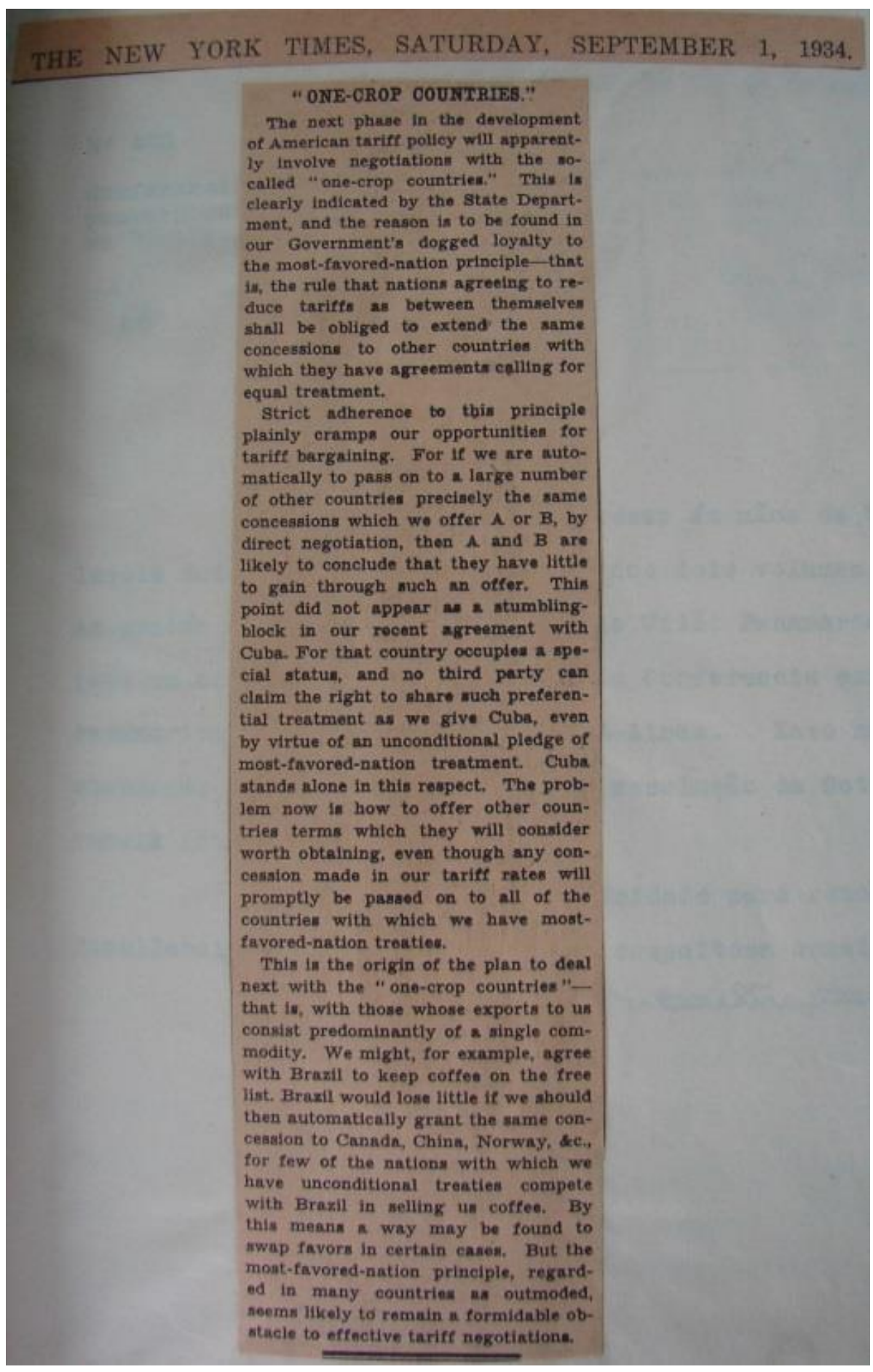

Figura 4.1 - Recorte ("Clipping") feito por diplomatas brasileiros, residentes em Washington, contendo reportagem publicada no jornal norte-americano The New York Times.

Fonte: Arquivo Itamaraty, Rio de Janeiro. 


\section{Capítulo 5 - A Negociação do Tratado}

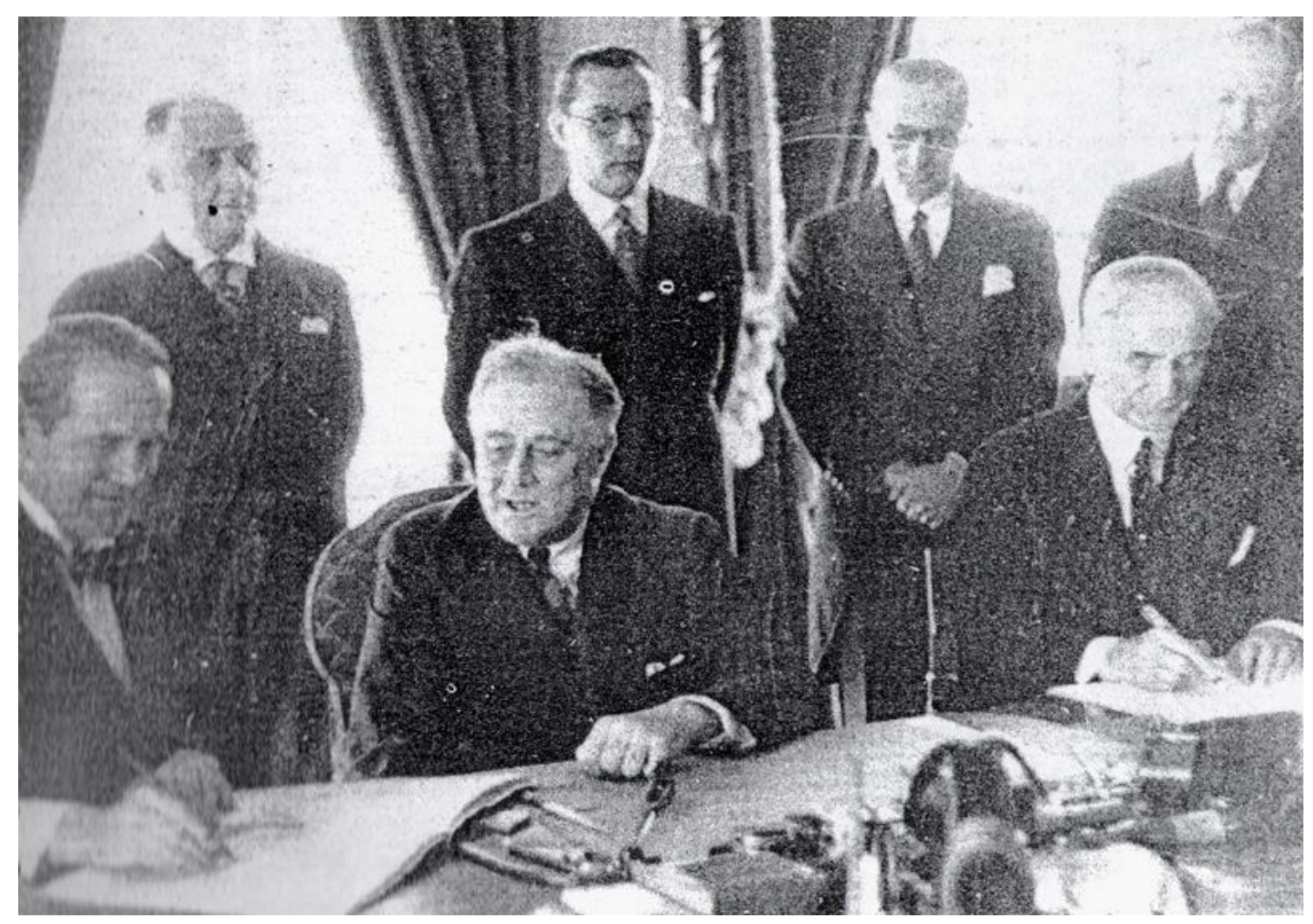

Figura 5.1 - Fotografia: A assinatura do Tratado de Comércio entre Brasil e Estados Unidos, 02/02/1935. Estão presentes Osvaldo Aranha, o presidente Roosevelt e o Secretário de Estado norte-americano, Cordell Hull.

Fonte: MOURA, 1980.

\subsection{O contexto geral}

Os Estados Unidos da América foram o epicentro da crise mundial que veio à tona após o "Crash" da Bolsa de Nova York, em 1929, e se espalhou pelo mundo na década seguinte. Schoultz ${ }^{162}$ demonstra em seus estudos como os EUA procuraram modificar sua relação com os países da América Latina, antes marcadas pelo intervencionismo belicoso. Como uma busca de cooperação para a resolução dos problemas econômicos provocados pela crise, principalmente o estancamento dos fluxos do comércio mundial, procuraram adotar o que foi chamado de "Política da Boa Vizinhança", aproximando-se econômica e politicamente dos governos da região e, ao mesmo tempo, buscando construir uma imagem "positiva" para os povos da América.

\footnotetext{
${ }^{162}$ SCHOULTZ, Lars. Estados Unidos: Poder e Submissão. Uma história da política norte-americana em relação à América Latina. São Paulo: Edusc, 2000, p 325-347.
} 
Foi realizada, em 1933, na cidade de Montevidéu, a Sétima Conferência de Estados Americanos, na qual os EUA procuraram assegurar aos demais países participantes, que adotariam como base de sua política externa a não-intervenção e a cooperação política e comercial. ${ }^{163}$ A ofensiva comercial que visava garantir a hegemonia econômica, bem como geopolítica dos EUA na América Latina, em face do gradual avanço da Alemanha naquele continente, havia se iniciado.

\subsection{A Iniciativa dos EUA}

Desde em 1927 e, portanto, bem antes da eclosão da crise econômica, o secretário de Estado do presidente Hoover, Frank Kellog, já havia sugerido que os EUA assinassem tratados comerciais baseados no princípio da reciprocidade. A opinião pública brasileira (principalmente a da oligarquia cafeeira paulista), contudo, viu com maus olhos esta iniciativa, desconfiando das intenções dos americanos, vistos como oportunistas. Além disso, o fato de que o café, de longe o principal produto de exportação do Brasil, já se encontrava então em uma lista de isenções tarifárias nos EUA, não propiciou maior interesse por parte do governo brasileiro. ${ }^{164}$

Após a ascensão de Franklin Delano Roosevelt à presidência, o Departamento de Estado dos EUA vinha tentando levar o Brasil à mesa de negociações desde meados de 1933. Com a aprovação da Lei de Acordos Comerciais Recíprocos, em 1934, o presidente dos EUA ganhou liberdade para afirmar acordos de comércio com reduções tarifarias de até $50 \%$, desde que houvesse garantias de reciprocidade por parte dos demais signatários de acordos comerciais. A negociação com o Brasil era vista como essencial e como um modelo para futuros tratados com outros países fornecedores de matérias primas. ${ }^{165}$

O presidente Getúlio Vargas declarou que, em princípio, acolhia a iniciativa, mas não fez qualquer esforço para dar seguimento às negociações. O governo brasileiro não estava particularmente entusiasmado com o novo tratado com os EUA, pois a sua cúpula administrativa não entendia as tarifas alfandegárias como problema central para a superação da crise e sim a escassez de crédito e divisas. ${ }^{166} \mathrm{O}$ então embaixador do Brasil em Washington, Rivaldo Lima e Silva, solicitou ao Departamento de Estado que apresentasse as bases do acordo. Estas consistiam na exigência recorrente, feita pelos

\footnotetext{
163 SCHOULTZ, op.cit., p 337.

164 BANDEIRA, Luiz Alberto Moniz. Presença dos Estados Unidos no Brasil. Rio de Janeiro: Civilização Brasileira, 2007, p. 339-370.

${ }^{165}$ HILTON, 1977, op. cit., p. 193.

${ }^{166}$ Carta de GV ao MRE, Rio de Janeiro, s.d., Arquivo GV.
} 
norte-americanos em todas as propostas de acordos antes apresentadas: a redução de tarifas para os produtos dos EUA, enquanto aquele país se comprometeria apenas a manter livre de taxas a entrada dos principais produtos brasileiros (café e borracha). ${ }^{167}$

O Governo dos EUA pressionou no sentido de uma resposta brasileira ao esboço inicial do Tratado, mas os brasileiros protelaram e, ao longo do ano seguinte, as conversações ficaram em estado de suspensão, devido principalmente à inação brasileira e às cisões internas nos EUA. ${ }^{168}$

\subsection{O cenário norte-americano}

Nos EUA, as opiniões acerca da política comercial planejada pelo Secretário Cordell Hull eram contraditórias. O quadro de interesses, no interior dos EUA, se configurava da seguinte maneira: os exportadores reclamavam continuamente dos atrasos em seus pagamentos; os portadores de títulos brasileiros de dívida externa demandavam o pagamento das dívidas e atrasados.

Dentro do próprio Departamento de Estado, havia uma corrente nacionalista e protecionista, liderada por George Peek, assessor do presidente para o comércio exterior, a qual propunha, a exemplo da Alemanha, uma solução baseada no comércio compensado. Já o Secretário de Estado Hull era um franco defensor da liberalização comercial e tinha respaldo do presidente Roosevelt, o qual, no entanto, em várias ocasiões, favorecia Peek. ${ }^{169}$

A opinião pública também refletia estas cisões e era permeada por diferentes interesses. Um artigo na imprensa americana, intitulado "U.S. negociating pact with Brazil to spur U.S. trade relations", aponta como objetivo do plano "restaurar a balança comercial do Brasil aos níveis de 1929, mas condicionado à compra de mais mercadorias dos EUA e o cumprimento de suas obrigações com este país, também concordando em não bloqueio das trocas comerciais". ${ }^{170}$

O artigo ressaltava ainda os danos causados ao comércio entre os dois países pelo declínio do preço internacional do café de 1929. Reforça ainda a importância das exportações americanas para o Brasil, notadamente de automóveis e a importância da importação de cera de Carnaúba do Brasil. Fica em destaque a representação da iniciativa do Tratado, como parte de um esforço de obtenção de vantagens econômicas mútuas, sem

\footnotetext{
${ }^{167}$ Nota de Lima e Silva ao MRE, Washington, 01/08/1933, Arquivo Itamaraty.

${ }^{168}$ BANDEIRA, op. cit., p.340.

169 D'ARAUJO e MOURA, op. cit., p. 59.

170 Journal of Commerce and Commercial, New York, 01/09/1934, Arquivo Itamaraty
} 
exigir qualquer forma de preferência em um sinal de "boa vontade dos EUA para a abertura dos mercados mundiais". 171

Em ofício endereçado ao MRE o representante diplomático encarregado do recorte destas notícias fez a seguinte observação: "a ideia, segundo o informador desse jornal, seria a de levantar o preço do café ao nível de 1929, a fim de melhorar a balança de pagamentos do Brasil e permitir-lhe fazer face ao pagamento de suas letras de importação e de sua dívida. O lucro que o Brasil haveria de tirar desta política teria que ser empregado exclusivamente em beneficio dos EUA". ${ }^{172}$

Fica evidente nos discursos acima, que a preocupação central de boa parte dos atores nos EUA era com a possibilidade de que, por via do impulso às exportações brasileiras, um acordo poderia propiciar saldos comerciais, os quais, por sua vez, proporcionariam a entrada de divisas, as quais finalmente serviriam para saldar as dívidas com credores, exportadores e portadores de títulos brasileiros nos EUA.

Um artigo, publicado no New York Times, enfocava as mudanças na política comercial dos EUA com relação a países que eles denominam de monocultores ("onecrop countries"), tais como o Brasil. Criticava, porém, fortemente a adoção do principio de nação mais favorecida, devido ao fato de que "tal principio limitaria muito as oportunidades para a negociação de tarifas". Estes debates mostram que a opinião pública nos EUA se encontrava dividida, com relação aos planos do Departamento de Estado de assinar acordos de reciprocidade com países latino-americanos. ${ }^{173}$

Um ofício da embaixada brasileira em Washington, endereçado ao MRE, trazia anexo um memorando da diretoria de uma associação ligada aos importadores e distribuidores de café norte-americanos, a Associated Coffe of America. O referido memorando apontava indícios de várias pressões para a taxação do café, mas que os "rumores a cerca de uma taxa de importação do produto seriam infundados". ${ }^{174}$

Um artigo publicado no The Journal of Commerce and Commercial exalta a nomeação de Osvaldo Aranha e traz um depoimento de James A. Carson, vice-presidente da Eletric Bond \& Share Co, saúda a possibilidade de que Aranha facilite a assinatura de acordos que aproxime a relação entre os países, condenando o que ele chamou "ultranacionalismo", com argumentos baseados na teoria das vantagens comparativas:

\footnotetext{
${ }^{171}$ Idem.

172 Ofício no402, embaixada de Washington ao MRE, 10/09/1934, Arquivo Itamaraty.

${ }^{173}$ New York Times, New York, 01/09/1934, Arquivo Itamaraty.

174 Oficio nำ406, Washington, 10/09/1934, Arquivo Itamaraty.
} 
(...) nós, do norte, estamos particularmente bem equipados para fornecer maquinário industrial de mineração e agrícola e de construção, mobiliário, automóveis e caminhões. (...) Pela razão que tanto sua qualidade quanto seu custo são superiores à de bens semelhantes produzidos em qualquer outro lugar. Brasil, por outro lado, pode produzir de forma mais barata e eficiente que qualquer outro lugar, mercadorias [como o café, cacau, borracha, minério de manganês, etc.] que nós necessitamos. ${ }^{175}$

Nos discursos acima, é evidente as concepções acerca de uma "ordem internacional", que devia se estruturar em função da hegemonia estadunidense e de uma ordem econômica (ou um arranjo específico da economia mundial), caracterizado pela inserção do Brasil e da América Latina nesse quadro como fornecedores de matériasprimas, principalmente de origem agrícola, e mercados consumidores para os produtos manufaturados dos EUA.

\subsection{O governo dos EUA pressiona o Brasil}

Em 12 de julho de 1933, o Departamento de Estado propôs ao governo brasileiro o início das rodadas de negociação acerca dos termos do Tratado. A proposta vinha acompanhada de listas de produtos de ambos os países para os quais se devia conceder isenção ou reduções tarifárias. Noticias na imprensa a respeito das iminentes negociações com a Alemanha para a assinatura de um tratado de comércio compensado, preocuparam as autoridades norte-americanas, especialmente o Secretário-adjunto de Estado, Summer Welles. Estes temiam, sobretudo, a evasão das escassas divisas brasileiras e o risco do não pagamento da dívida e dos atrasados comerciais. ${ }^{176}$

O Departamento de Estado dos EUA ameaçou o Brasil com sanções econômicas caso este assinasse um acordo formal com a Alemanha. Retirar o café da lista de isenções era a principal ameaça, sendo importante lembrar que, em 1934, os EUA absorveram quase $55 \%$ de todas as exportações brasileiras de café. ${ }^{177}$ Vargas, em face desta oposição, desistiu de formalizar o referido acordo germano-brasileiro, mas obteve um acordo informal que funcionou efetivamente até a elaboração de um novo arranjo comercial, também informal, com aquele país, em $1936 .{ }^{178}$

Quando o projeto completo do tratado, de concepção estadunidense, chegou ao Brasil, em dezembro de 1934, gerou grande polêmica principalmente por conter uma

\footnotetext{
175 Journal of Commerce and Commercial, New York, 14/09/1934, Arquivo Itamaraty.

${ }^{176}$ HILTON, 1977, op. cit, p. 199.

${ }^{177}$ WIRTH, op. cit., p. 5.

${ }^{178}$ Idem, ibidem, p. 98.
} 
clausula relativa ao tratamento cambial, a qual, segundo o MRE, tiraria a liberdade de negociação comercial do Brasil. ${ }^{179}$

Além disso, havia segmentos da cafeicultura brasileira que nutriam boas esperanças de aumentar o volume de vendas com um acordo com a Alemanha. A partir de 1934, a influência norte-americana sobre o comércio internacional do Brasil cedeu terreno à influência Alemã. De modo geral, o comércio exterior do Brasil na década de 1930 se caracterizou pelo declínio da importância relativa do café, pela importância crescente do algodão e pela significação cada vez maior da Alemanha como mercado para os produtos brasileiros. As exportações alemãs para o Brasil aumentaram de 12,7\% do mercado brasileiro, 1929, para 25\% em 1938. Enquanto isso, dados referentes ao mesmo período revelam que o marcante predomínio americano de outrora se havia reduzido de $30,1 \%$ para $24,2 \%$, ao passo que as exportações britânicas tinham caído de $19,2 \%$ para pouco mais da metade, ou seja, $10,4 \%{ }^{180}$

Representantes do Itamaraty também admitiam o pouco interesse do corpo diplomático em avançar as negociações. Como reconhece o conselheiro Feitas-Valle, adido comercial em Washington, "O motivo sério para procurarmos o tratado de comércio é, de evidência, a vontade que se encontra este governo [dos EUA] de realizá$10 " .181$

\subsection{A atuação de Osvaldo Aranha e a assinatura do Tratado}

Nomeado embaixador do Brasil em Washington, em 1934, Osvaldo Aranha, um amigo de Vargas e seu ex-ministro da Fazenda, assumia declarada tendência pró-EUA. Chegou a Washington, entendendo que a posição do Brasil com relação às demandas daquele governo, era bastante precária: “Ou seguimos a política liberal ou ele [governo americano] se vê forçado a aplicar-nos a antiliberal". ${ }^{182}$ Tratou de buscar a retomada das negociações do Tratado, com vistas a melhorar as relações com o vizinho do Norte.

Em memorando ao MRE, Aranha declarou que "as negociações foram proteladas por nós, que nunca apresentamos nossa contraproposta, nem demos razões dessa atitude, mantendo-nos em evasivas". Ainda sugeriu o embaixador que a proposta americana deixaria o Brasil com ampla margem de manobra. Alerta, na mesma carta, quanto ao acirramento da posição estadunidense, que passou a ser pautada pela condenação

\footnotetext{
${ }^{179}$ Ofício MRE a OA, Rio de Janeiro, 24/12/1934, Arquivo Itamaraty.

${ }^{180}$ WIRTH, op. cit., p. 5-7.

${ }^{181}$ Carta de Freitas-Valle a Calvacante de Lacerda, Washington, 19/07/1934, Arquivo Itamaraty.

${ }^{182}$ Carta de OA a MS, Washington, 30/10/1934, Arquivo Itamaraty.
} 
veemente dos tratados bilaterais e pela pressão pela liberalização comercial. As posturas com relação à América Latina seriam, segundo Aranha, cada vez mais endurecidas. ${ }^{183}$

Aranha considerava o tratado pouco capaz de afetar substancialmente o comércio internacional brasileiro, uma vez que $97 \%$ das exportações brasileiras para os EUA já não pagavam tarifas e assim permaneceriam, e os produtos americanos para os quais se solicitava tarifas mais baixas no Brasil já tinham um preço de venda local mais alto do que de seus concorrentes. Sendo assim, a concessão tarifária não traria vantagens especiais aos produtos industriais americanos. ${ }^{184}$ Em outra correspondência, esta de caráter pessoal, endereçada a Macedo Soares, reforçou sua posição pró-americana, afirmando que o entendimento com os EUA era "altamente favorável aos nossos interesses e a nossa posição internacional". ${ }^{185}$

Já no início de janeiro de 1935, o Ministro da Fazenda, Arthur de Souza Costa, foi enviado aos EUA em missão para negociar as questões dos congelados comerciais brasileiros e outras relativas à dívida com aquele país. Aproveitaria para buscar uma solução para as negociações do Tratado. Aranha se sentiu pessoalmente ofendido e ferido em seu prestígio com esta missão e declarou isso a Vargas. ${ }^{186}$ Após sua partida, Aranha resolveu acelerar a finalização do acordo.

Dois fatos inesperados acabaram por trazer dificuldades de última hora: a deterioração da situação cambial brasileira e a substituição do Secretário-Adjunto de Estado, Summer Welles, o qual vinha se encarregando dos ajustes finais. Os estadunidenses insistiam na cláusula de ajuste cambial, a qual dava preferência na utilização das divisas para os pagamentos aos EUA e era indesejada pelas autoridades brasileiras. O boato de um (falso) acordo entre Brasil e Itália, divulgado no Brasil, levou o Departamento de Estado a entregar um projeto de Tratado, com exigências mínimas. Aranha conseguiu que a referida cláusula fosse ligeiramente alterada, de forma que se tornasse aceitável pelo governo brasileiro.

Com relutância, os negociadores dos EUA aceitaram o texto preparado por Aranha, o que permitiu que o Tratado fosse finalmente assinado, quase dois anos após

\footnotetext{
${ }^{183}$ Memorando de OA ao MRE, 1935, apud. CAMARGO, A. et alii. (orgs.). Osvaldo Aranha: a estrela da revolução. São Paulo: Mandarim, 1996, p. 116.

${ }^{184}$ Carta de OA a MS, Washington, 30/10/1934, Arquivo Itamaraty.

${ }^{185}$ Carta de OA a MS, Washington, 12/02/1935, Arquivo OA.

${ }^{186}$ Carta de OA a GV, Washington, 09/01/1935, Arquivo OA.
} 
sua proposição original, pelo embaixador do Brasil e o secretário Hull, na presença do presidente Roosevelt e do ministro Souza Costa, em dois de fevereiro de $1935 .{ }^{187}$

\subsection{Os termos do Tratado}

O Texto do Tratado de Comércio entre os Estados Unidos do Brasil e os Estados Unidos da América, em linguagem diplomática, explicita o "desejo de fortalecer os tradicionais laços de amizade entre os dois países”. Contém 14 artigos e duas listas de produtos, com as correspondentes alíquotas de redução, ou isenções, tarifárias. O seu Artigo I traz a "cláusula de nação mais favorecida", já o Artigo III, o mais relevante para o governo brasileiro, garante a manutenção dos produtos brasileiros já constantes da lista de isenções tarifárias nos EUA. Uma análise das listas de mercadorias nos leva à conclusão de que o Tratado de fato favorece a importação pelo Brasil de produtos manufaturados, notadamente máquinas, geladeiras, automóveis e tecidos, em troca da manutenção da isenção de alguns produtos primários de exportação brasileira, principalmente o café, cacau, mate, castanhas, minério e cera de carnaúba. ${ }^{188}$

\subsection{O que se seguiu: os debates acerca da ratificação e seu desfecho final}

Após a assinatura do Tratado, de acordo com a constituição brasileira de 1934, ele deveria ser ratificado pelo Congresso Nacional e, posteriormente, sancionado pelo Presidente da República, para então tornar-se vigente. Até então, todas as negociações retratadas acima haviam sido conduzidas em sigilo (como de fato era então bastante comum no caso brasileiro). Somente os membros da cúpula do governo, o próprio Vargas, o Ministro das Relações Exteriores, Jose Carlos de Macedo Soares, o Ministro da Fazenda, Arthur de Souza Costa e o corpo diplomático brasileiro em Washington, chefiado pelo embaixador Osvaldo Aranha, tomaram parte na negociação e conheciam dos termos do Tratado. É interessante que, apesar da divulgação na imprensa estadunidense, nada se falava acerca das negociações no Brasil.

Contudo, uma vez assinado, o Tratado foi tornado público por nota do governo ao congresso, em fevereiro de 1935. Neste momento começaram os debates, que são objeto da presente dissertação. Como será visto, a questão da ratificação do Tratado suscitou um amplo debate e mobilizou grupos diversos, contra e a favor, no Congresso, no Conselho Federal de Comércio Exterior, na FIESP e na Imprensa. As discussões no Congresso

${ }^{187}$ CAMARGO et. Alii., op. cit., p. 119-120.

${ }^{188}$ Cf. Decreto N. 542, de dois de dezembro de 1935, (URL: www.camara.gov.br). 
foram particularmente encarniçadas e se alongaram muito. Desde a apresentação da nota do Executivo, motivando o projeto de ratificação, em fevereiro, até a primeira apreciação, em abril de 1935, a votação foi sucessivamente protelada e só voltou-se a discuti-la, já entre o fim de agosto e início de setembro daquele ano.

O secretário de Estado norte-americano, Cordell Hull, se mostrou cada vez mais apreensivo com a demora das negociações. Chegou a tentar convencer diretamente ao líder industrial Euvaldo Lodi das vantagens da assinatura do tratado. A apreensão no Departamento de Estado aumentou com a aprovação dada pelo CFCE ao Banco do Brasil para operações de comércio compensado com a Alemanha. ${ }^{189}$

Em agosto de 1935, o Departamento de Estado norte-americano aumentou a pressão, intercedendo junto ao conselheiro Cyro de Freitas-Valle, na embaixada brasileira em Washington e junto ao embaixador Osvaldo Aranha. Ameaçando o governo brasileiro com possíveis represálias tarifárias, e especificamente sobre o café, o secretário Hull pressionou o ministro Macedo Soares, quem por sua vez, repassou a mensagem para Vargas.

O presidente convocou o líder da maioria da câmara dando instruções para acelerar a ratificação. Chamou também Euvaldo Lodi e ameaçou tornar públicas suas desavenças caso os industriais continuassem a obstruir sua aprovação. Além disso, o ministro Macedo Soares, atuou junto à Comissão de Agricultura da câmara visando obter a votação imediata da ratificação e a conseguiu. Com esta pressão direta, por parte do próprio presidente Vargas, o Tratado foi aprovado por 120 votos contra $51 .{ }^{190}$ É sancionado finalmente, pelo presidente Vargas, através do Decreto n. 524, de 24 de dezembro de 1935.

Após breve recapitulação dos episódios relativos à negociação e assinatura do Tratado, realizada acima, passemos ao objeto mais específico da presente dissertação: a análise do debate que se seguiu à divulgação do Tratado e precedeu sua ratificação parlamentar, nas várias instâncias em que teve lugar em solo brasileiro.

\footnotetext{
${ }^{189}$ Telegramas de Hull a Gordon, Washington, 28/05/1935 e 21/06/1935, apud. Ofício Washington ao MRE, 02/07/1935, Arquivo Itamaraty.

${ }^{190}$ D’ARAÚJO e Moura, op. cit., p. 66.
} 


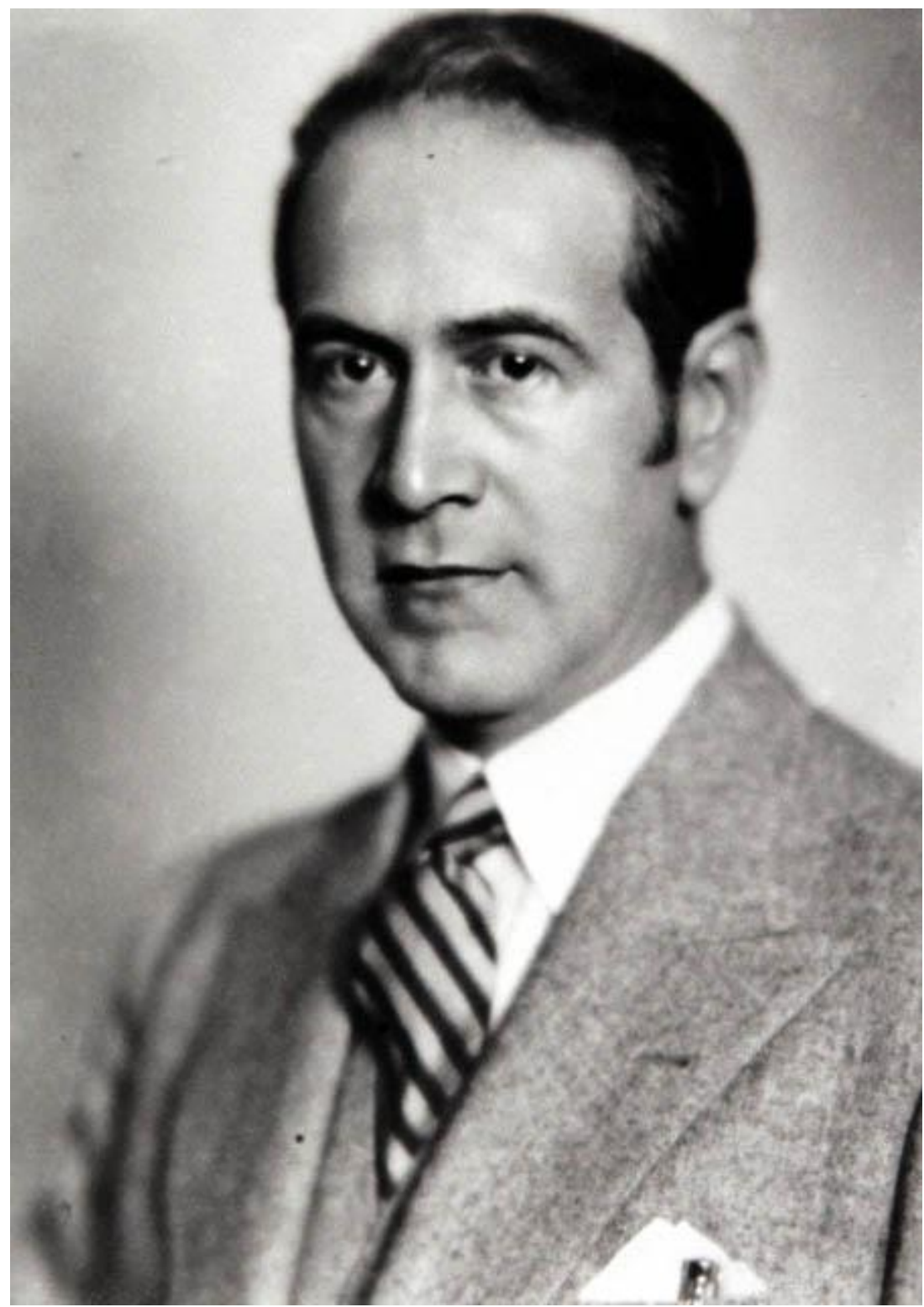

Figura 5.2. - Fotografia de Osvaldo Aranha (s.d.).

Fonte: Wikimedia commons. URL:

http://pt.wikipedia.org/wiki/Osvaldo_Aranha. (acessado em 20/05/2014). 


\section{Capítulo 6 - O Debate no Âmbito do Governo Federal}

\subsection{As discussões no Conselho Federal de Comércio Exterior}

Criado em junho de 1934 com a finalidade de centralizar a política de comércio exterior do país, o Conselho Federal de Comércio Exterior (CFCE) era um órgão consultivo, vinculado ao governo federal, o qual se inseria em um projeto mais amplo, que visava à centralização político-administrativa e a atuação coordenada do Estado na esfera econômica nacional. Diretamente subordinado à Presidência da República (e em várias ocasiões presidido pelo próprio Vargas), o CFCE cumpria funções de planejamento econômico, tendo como uma de suas atribuições coordenar a atividade de outros órgãos de política econômica. Foi também um locus de uma modalidade corporativa de representação de interesses de classes e frações destas, no próprio seio do Estado. $^{191}$

Composto por representantes dos ministérios das Relações Exteriores, Fazenda, Agricultura, Trabalho, Indústria e Comércio, Viação e Obras Públicas, do Banco do Brasil e da Associação Comercial, todos designados pelo presidente da República, com a ampliação de suas funções, o Conselho passou a incluir também representantes de entidades privadas. Sua estrutura organizativa era baseada em três câmaras: a de crédito e propaganda, a de produção, tarifa e transportes, e a de comércio e acordos. Os membros eram rotativos e sua composição mudava periodicamente. Suas decisões eram transformadas em lei somente após serem referendadas pelo presidente da República. ${ }^{192}$

Por volta de Agosto de 1934, sua composição era a que se segue. Presidido por Getúlio Vargas, era composto pelos membros: Sebastião Sampaio, Marcos de Souza Dantas, Antônio Eduardo de Lenhoff Brito, Arthur de Carvalho, Arthur Torres Filho, Clovis Ribeiro, Valentin Bouças, Armando Vidal Leite Ribeiro, J. M. de Lacerda, Raul de Araújo Maia e Euvaldo Lodi.

O CFCE foi também um dos palcos privilegiados no debate acerca do Tratado, contudo, nele falaram mais alto os seus críticos, com destaque para a atuação dos industrialistas, principalmente Euvaldo Lodi. Este líder da classe industrial afirmou estar

\footnotetext{
${ }^{191}$ Acerca da criação e do significado e caracterização do CFCE, bem como dos diversos conselhos técnicos criados no período, ver DINIZ, 1977, op. cit.

192 Fonte: CPDOC/FGV - URL: http://cpdoc.fgv.br/producao/dossies/AEraVargas1/anos37-

45/EstadoEconomia/ConselhoComercioExterior - consultado em 01/02/2013.
} 
na posse de várias reclamações contra as alterações tarifárias constantes do tratado assinado com os Estados Unidos por parte de empresários. Aproveitou para criticar o sigilo da negociação do acordo: "os interessados têm tido conhecimento por intermédio de telegramas particulares e de publicações nos jornais de Nova York". ${ }^{193}$

Lodi ainda manifestou sua intenção de propor alterações no tratado e até de retardar a ratificação na Câmara. Justificou essa atitude pelo fato de então haver um ambiente desfavorável ao acordo, principalmente por este ter favorecido artigos de consumo feitos nos EUA que teriam similares produzidos por fábricas nacionais, algumas das quais já em estado de superprodução. ${ }^{194}$

Vários outros representantes da indústria chegaram a compor o quadro do CFCE, tais como Guilherme Guinle, Mario Ramos, Luiz Betim Paes Leme e Roberto Simonsen. Os que se manifestaram, o fizeram sempre contra o Tratado.

Grupos de interesse regionais, notavelmente os ligados a comunidade alemã do Rio Grande do Sul, produtores pecuários e plantadores de fumo e cacau da Bahia pressionaram, nas sessões do CFCE através de seus representantes, a favor de um acordo de compensação com a Alemanha, interessados no potencial dos mercados daquele país para os seus produtos. ${ }^{195}$ Portanto, se posicionavam em contrário às disposições do Tratado com os EUA, o qual vedava este tipo de tratados bilaterais. Sebastião Sampaio e Souza Dantas pressionaram, em outra reunião do conselho, em favor de um acordo com a Alemanha. ${ }^{196}$

Em reunião do CFCE, ainda em 1934, Sebastião Sampaio, Souza Dantas e Valentin Bouças ressaltaram como o problema dos "congelados comerciais" causavam danos para as relações comerciais do Brasil. Sampaio enfatizou a pressão exercida sobre o governo dos EUA pelos exportadores daquele país para que o Brasil honrasse seus compromissos, sendo que para ele, a base das negociações com os EUA deveria ser a questão dos "congelados" e não a das tarifas alfandegárias. Souza Dantas, nesta mesma reunião, apresenta um projeto para a discussão, propondo a "fatalidade de se aceitar um acordo de compensação" e considera essencial a questão do equilíbrio orçamentário. ${ }^{197}$

Em correspondência a Osvaldo Aranha, Valentim Bouças afirma ter sido chamado a uma reunião do CFCE, na qual, teria sido violentamente atacado por sua posição

\footnotetext{
193 Arquivo Nacional (RJ), CFCE - lata 4, 1935, Ata da 29ạ. Sessão, 25/02/1935.

194 Arquivo Nacional, op. cit. - Ata da 44á. Sessão, 17/06/1935.

195 Arquivo Nacional, op. cit. - Ata da 11a. Sessão, s.d. ,1935.

196 Atas do CFCE, apud. Hilton, 1977, op. cit., p. 115-116.

197 Arquivo Nacional, Ata da 2ạ sessão do CFCE, Rio de Janeiro 10/08/1934, CFCE, Lata 3.
} 
contrária ao comércio compensado. Em tal reunião, Bouças teria ainda defendido explicitamente o tratado, segundo seus "princípios de economia, baseada no bom senso e nos interesses nacionais e que eu não tinha culpa que esses nossos interesses beneficiassem o tratado americano". Ainda nesta correspondência, deixa clara a disposição majoritariamente contrária dos conselheiros com relação ao tratado. ${ }^{198}$

Fica claro, a partir da análise das atas do CFCE no período, que, apesar de manifestações esporádicas de Valentim Bouças em defesa do Tratado, o clima no CFCE foi dominado por posições contrárias à sua ratificação. Mas quais seriam as possíveis explicações para este fato?

Numa primeira aproximação, observa-se o grande número de seus membros, acima referidos, que representavam a fração industrial. E, como a historiografia e nossas próprias análises indicaram, esta fração formou posição coesa contra o Tratado. Digno de nota também é o fato de que seus membros não pertenciam à burocracia estatal propriamente dita, neste período em que foram travados os debates.

Nem mesmo os membros vinculados à produção agrária, ou ao comércio de importação/exportação se manifestaram em defesa do Tratado. A exceção importante foi certamente Valentim Bouças. Contudo, como será visto no capitulo acerca do debate nas associações de classe, ${ }^{199}$ a sua posição pode ter sido mais explicável por motivos particulares do que interesses mais gerais de sua fração de classe.

\subsection{Debates e cisões na cúpula do poder.}

Além disso, corria junto um debate diretamente correlato ao do Tratado, sobre a oportunidade de aproximação com a Alemanha, o qual igualmente revelava cisões dentro do governo brasileiro. De um lado Sebastião Sampaio e Souza Dantas, além dos Generais Dutra e Góis Monteiro, pró-Alemanha, de outro Osvaldo Aranha, Souza Costa, pró-EUA.

Quando Getúlio Vargas chegou ao poder, através do movimento que se autodenominou Revolução de 1930, formou um ministério, composto por velhos e jovens políticos, alguns deles muito próximos do presidente. Esse é o caso de Osvaldo Euclides de Sousa Aranha, político gaúcho, articulador da campanha da Aliança Liberal e da Revolução de 1930. Foi Ministro da Fazenda (1931-1934), embaixador do Brasil nos EUA (1934-1938) e Ministro das Relações Exteriores (1938-1944), durante praticamente

\footnotetext{
${ }^{198}$ Carta de Bouças a OA, Rio de Janeiro, 25/06/1936, Arquivo OA.

${ }^{199}$ Cf. Capítulo 8 desta dissertação.
} 
todo período do Primeiro Governo Vargas. Figura muito influente, junto ao presidente, Aranha era também um dos maiores proponentes da aproximação econômica e do alinhamento geopolítico do Brasil com os EUA. ${ }^{200}$

Aranha instou em inúmeras ocasiões, via correspondência, para que Getúlio Vargas pressionasse os parlamentares a favor da ratificação. Para Aranha, o tratado abriria "novas possibilidades nas relações comerciais entre o Brasil e os EUA [trazendo] os elementos básicos das novas indústrias, máquinas e engenhos". ${ }^{201} \mathrm{O}$ embaixador ainda apelava para que Vargas neutralizasse a ação dos líderes industriais: "dizem que a aprovação do tratado está perigando, porque o lobbyismo está sendo feito junto aos nossos Deputados pelos industriais de São Paulo". ${ }^{202}$ Para ele, os industriais Brasileiros tinham uma visão econômica corporativa ligada aos seus interesses específicos e "alheia aos interesses nacionais". 203

Em longa correspondência a Vargas, no início de janeiro de 1935, Osvaldo Aranha expõe críticas às propostas de adoção do comércio compensado, por acarretarem a perda dos saldos do comércio externo, necessários para fazer face aos compromissos financeiros do Estado. Além disso, nesta mesma correspondência, Aranha relata as ameaças e, segundo ele, possibilidades concretas de taxação sobre a entrada do café no mercado norte-americano caso o tratado não fosse finalizado. Termina com uma defesa categórica do tratado:

O certo, porém, Getúlio, é que no tratado projetado não perdemos nada, consolidamos tudo que nos é favorável, ficamos com liberdade de negociar com os demais e abrimos possibilidades imensas que devem concretizar-se em acordos especiais. $^{204}$

Em correspondência ao ministro Macedo Soares, Osvaldo Aranha defende uma orientação liberal de política comercial. Ressalta o clima cauteloso dos americanos e alerta contra a possibilidade de retaliações, culpando a atuação diplomática Alemã pelo referido clima. Contudo, afirma ser necessária cautela, a fim de "não perder de vista até onde isso [as exigências americanas quanto ao tratado] poderá nos submeter a este país. É

\footnotetext{
${ }^{200}$ Para uma abrangente análise da carreira política de Oswaldo Aranha, ver CAMARGO et. Alii, op. cit.

${ }^{201}$ Correspondência de OA para GV, Washington, 28/06/1935, Arquivo GV.

202 Carta de OA a GV, Washington, 01/07/1935, Arquivo OA.

${ }^{203}$ Carta de OA a GV, Washington, 24/09/1935, Arquivo OA.

${ }^{204}$ Carta de OA a GV, Washington, 08/01/1935, Arquivo OA.
} 
capital resguardar este aspecto fundamental a nossa soberania. Não queremos nem podemos aceitar vassalagens mesmo indiretas". 205

Em correspondência ao ministro Souza Costa, Osvaldo Aranha afirma que "ele foi e é o melhor tratado que poderia se obter neste país". Critica veementemente as opiniões contrárias ao tratado, principalmente a dos industriais, chamando-os de criminosos "que querem demais". "Acho graça nesses enlutados com bolsos cheios, comendo e bebendo a custa do Brasil, cuja falência, entretanto vivem a pregar em discursos ridículos (...) sem patriotismo". E com essa e outras criticas endereçadas a oposição, principalmente a Otávio Mangabeira, exorta Costa a agir decisivamente na câmara e pede uma ação conjunta de todos os elementos da cúpula do governo que deveriam "organizarem-se todos ao redor de Getúlio" e da posição oficial a favor do tratado. ${ }^{206}$

Fica evidente na passagem acima o viés anti-industrialista de Aranha, o qual demonstrava (ao menos nesse período que estudamos), estar aferrado a uma concepção tradicional acerca do Brasil e exibia uma visão estratégica da inserção do Brasil na economia mundial, baseada na produção agrária, com uma visão negativa da indústria nacional. Além disso, como já assinalado, sua evidente disposição pró-estadunidense.

José Carlos de Macedo Soares, jurista, historiador e político paulista ocupava o cargo de ministro das relações exteriores. Macedo Soares defendia a assinatura do Tratado e contava com a atuação mais decisiva de Osvaldo Aranha junto aos negociadores dos EUA. Apesar de ocupar o cargo máximo do Itamaraty, o envolvimento direto de Macedo Soares na negociação do Tratado foi bastante restrito, circunscrevendose à defesa de sua consecução, junto à Vargas. Para a negociação, Soares declaradamente confiava em Aranha para leva-la adiante. ${ }^{207}$

Já Arthur da Souza Costa, o Ministro da Fazenda de Vargas era, segundo Hilton, uma figura de decisiva influência sobre a política econômica federal e possuía uma concepção eminentemente conservadora, imbuído de um pensamento liberal e oposto a “interferência nos mecanismos naturais do mercado", o que o predispunha a ser contrário a acordos de compensação. Contudo, passou a partir da crise cambial de 1935 a ver tais acordos como potencialmente inevitáveis. ${ }^{208}$

\footnotetext{
${ }^{205}$ Correspondência Oficial de OA ao Ministro das Relações Exteriores, Washington 30/10/1934, Arquivo Itamaraty.

${ }^{206}$ Carta de OA a Souza Costa, Washington 18/06/1935, Arquivo OA.

${ }^{207}$ Carta de Macedo Soares a OA. Rio de Janeiro, s.d., Arquivo OA.

${ }^{208}$ Cf. HILTON, 1977, op. cit., p. 91-92.
} 
Sebastião Sampaio, chefe da sessão comercial e econômica do Itamaraty e diretor executivo do CFCE, via no mercado alemão uma grande oportunidade e chegou a favorecer a aproximação com a Alemanha, chegando a afirmar que esta seria o melhor mercado para os interesses econômicos gerais para o Brasil do que os EUA, uma vez que estes últimos beneficiavam particularmente os estados produtores de café. Contudo, sob a influência do Ministro Macedo Sores, de quem era próximo, passou a defender, gradualmente, uma política pró-americana, justificando-a como "a mais adequada para os interesses nacionais". 209

Já o conselheiro Souza Dantas foi um dos principais defensores do acordo com a Alemanha, em detrimento da política comercial conduzida pelos EUA e em aberto desafio ao Tratado que vinha então sendo negociado em Washington. Obteve um acordo não oficial em 1934 com os alemães, o qual estipulava a troca de lã, algodão, couros e peles, fumo, borracha e outras matérias-primas para a indústria em troca de Marcos para compensação. $^{210}$

Por sua vez, alguns líderes militares, principalmente o alto comando das Forças Armadas, nas figuras dos generais Eurico Gaspar Dutra e Pedro A. de Góis Monteiro, percebiam uma fragilidade estratégica do Brasil, devida a "deficiências de aparelhamento", e se inclinavam na direção de uma aproximação com a Alemanha. Sua percepção era a de que o comércio compensado, num quadro de escassez crônica de divisas seria o caminho mais profícuo, tanto para a obtenção de veículos, máquinas e material bélico, quando para o projeto futuro de um desenvolvimento de indústrias de base nacionais, o qual se ligava à sua concepção de segurança nacional. ${ }^{211}$

O principal defensor do tratado no interior do governo foi sem dúvida Osvaldo Aranha, como pode ser verificado, bem como, por decorrência, o maior opositor da proposta de um acordo com a Alemanha, como se atesta em correspondência com Vargas: "os EUA contam bastante com o Brasil na luta contra o nocivo bilateralismo Alemão". 212

A tomada de decisões estava sujeita, portanto, a influências do quadro internacional e a exigências conflitantes dentro do país. O caráter difuso do programa de ação espelhava as discordâncias internas dentro dos ministérios e entre os principais conselheiros com relação aos objetivos. Segundo Wirth, não é de surpreender, portanto,

\footnotetext{
${ }^{209}$ Idem, ibidem, p. 102-103.

210 Idem, ibidem, p. 108.

${ }^{211}$ Idem, ibidem, p. 113-117.

${ }^{212}$ Carta de OA a GV, Washington, 15/01/1935, Arquivo GV.
} 
que o governo desse ênfase à exportação, uma politica para a qual lhe era possível manter amplo apoio. Dai a existência de uma constante no comércio exterior do Brasil: a manutenção, expansão e diversificação dos mercados. ${ }^{213}$ Contudo, ainda segundo o autor, "se todas as solicitações norte-americanas de redução de tarifas fossem atendidas, o governo temia perder fontes essenciais de receitas". 214

Já quanto ao próprio Vargas, este via os laços econômicos do Brasil com os EUA como determinantes para a política externa nacional e aconselhava a ampliação do comércio com aquele país aos CFCE e ao MRE em 1934. O tratado foi encarado por Vargas sem entusiasmo, uma vez que a balança comercial com os EUA estava deficitária no período entre 1933 e $1934 .^{215}$ Em carta a Osvaldo Aranha, de meados de outubro de 1934, Vargas torna clara sua visão de que o tratado poderia ser assinado, porém que não era necessariamente desejado pelo presidente: "Ou fazemos um tratado para melhorar nossas relações econômicas ou deixamos tudo como está, o que não é mau". ${ }^{216}$

Getúlio Vargas em seu diário pessoal registrou, entre os dias em e três de fevereiro de 1935, franca satisfação com o fim do processo de negociações, afirmando: "a ocorrência mais importante destes dias foi a assinatura do tratado comercial com os Estados Unidos, depois de variada troca de correspondência e conversas telefônicas diretas daqui para Washington. Na minha correspondência particular com o Osvaldo [Aranha], venho continuamente sugerindo a necessidade de uma maior aproximação com aquele país no sentido político”. Tal passagem ilustra como Vargas entendia a importância do tratado como de carácter, muito mais político, do que econômico. ${ }^{217}$

\subsection{Considerações gerais}

Para além das cisões e divergências demarcadas, a cúpula do poder acabou por se alinhar na defesa do Tratado, após a mudança na atitude de Vargas, por volta de setembro de 1935, quando este passou a pressionar os opositores de sua ratificação, na Câmara dos deputados. Do que se pode depreender das considerações de Vargas e aranha, mais do que a questão econômica, propriamente dita, o que estava em jogo eram questões estratégicas e geopolíticas. Vargas não pretendia abrir mão de sua posição de autonomia relativa, dentro do quadro de dependência. Percebia claramente que se opor aos EUA

\footnotetext{
${ }^{213}$ WIRTH, op. cit., p.5.

${ }^{214}$ Idem, ibidem, p. 10.

${ }^{215}$ Idem, ibidem, p. 109.

${ }^{216}$ Carta de GV a OA, Rio de Janeiro 16/10/1934, Arquivo OA.

${ }^{217}$ VARGAS, G. Getúlio Vargas: Diário. Leda Soares (ed.), v. 1. Rio de Janeiro: FGV, 1995, p. 357.
} 
nessa questão, eleita como de importância crucial para a estratégia hegemônica dos EUA frente à rivalidade germânica, não lhe traria benefícios.

Assim, optou por manter negociações concomitantes (e sigilosas) com a Alemanha, a fim de costurar acordos de comércio compensado, a fim de não abrir mão das vantagens evidentes deste canal de escoamento para as exportações brasileiras, sem transformá-los em tratados formais, o que violaria os termos de um tratado de "Nação mais favorecida", como este firmado com os EUA.

Nos documentos analisados, fica patente o predomínio de ideias e concepções tradicionais, principalmente - mas não somente - da parte de Osvaldo Aranha, Macedo Soares e outros defensores do Tratado. Mesmo os que o atacavam, no CFCE, ou nas trocas de correspondências com Vargas e seus ministros, não se referiam em nenhum momento ao "interesse da indústria". As questões aqui em jogo nos remetem mais às dimensões estratégicas e geopolíticas de alinhamento, bem como as questões mais gerais do crônico estancamento dos fluxos de troca internacionais no período. 


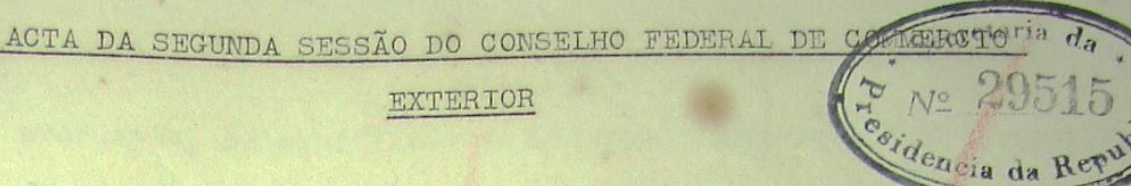

Aos treze dias do mez de Agosto de 1934, Kuma

das salas do Ministerio das Relações Exteriores reuniu-se

- Conselho Federal de Commercio Exterior, sob a presi-

dencia do Senhor Presidente da Republica e com a assistencia dos Senhores Ninistros da Fazenda e das Relacões Exteriores. Compareceram á sessão os Conselheiros Senhores Consul Geral Sebastião Sampaio, João Naria de Lacerda, Arthur de Carvalho, Narcos de Sousa Dantas, Raul de Araujo Naia, Euvaldo Lodi e Arthur Torres Filho, e os Consultores technicos Senhores Antonio Eduardo de Lenhoff-Brito, Léo da Affonseca e Valentim Bouças. Faltaram, com causa justificada, os Nembros do Conselho Senhores Armando Vidal e Victor Viana e - Consultor Technico Senhor Clovis Ribeiro. Lida a acta da sessão anterior, foi a mesma approvada, depois de rectificada pelos Senhores Sousa Dantas e Valentim Bouças, o primeiro na parte que diz respeito á proposta de adopção de"clearing", por Sua Excellencia apresentada e o segundo quanto á questão da divida externa. Iniciados os trabalhos, teve a palavra o senhor Sousa Dantas, que passou a lêr a sua proposta de "clearing", assignada por todos os membros da Camara de Commercio e Acôrdos. Essa proposta é a seguinte: "As difficuldades que se oppõem ao regular desenvolvimento dos negocios de exportação e importação vêm crescendo continuamente. Avultam entre ellas as decorrentes da criação dos "congelados". Ha grande atrazo no pagamento dos productos que importamos. Dahi, naturalmente, uma serie interminavel de protestos, reclamações, pedidos, propostas e até mesmo ameaças. Paizes credores do nosso, por fornecimentos de natureza commercial, insistem em nos propôr e mesmo em nos impôr accordos de compensação de proC.P.

Figura 6.1. Exemplo de ata de reunião do CFCE.

Fonte: Arquivo Nacional (CFCE, latas 3 e 4, 1934-1935). 


\section{Capítulo 7 - O Debate na Câmara dos Deputados}

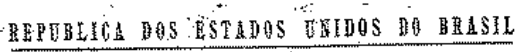
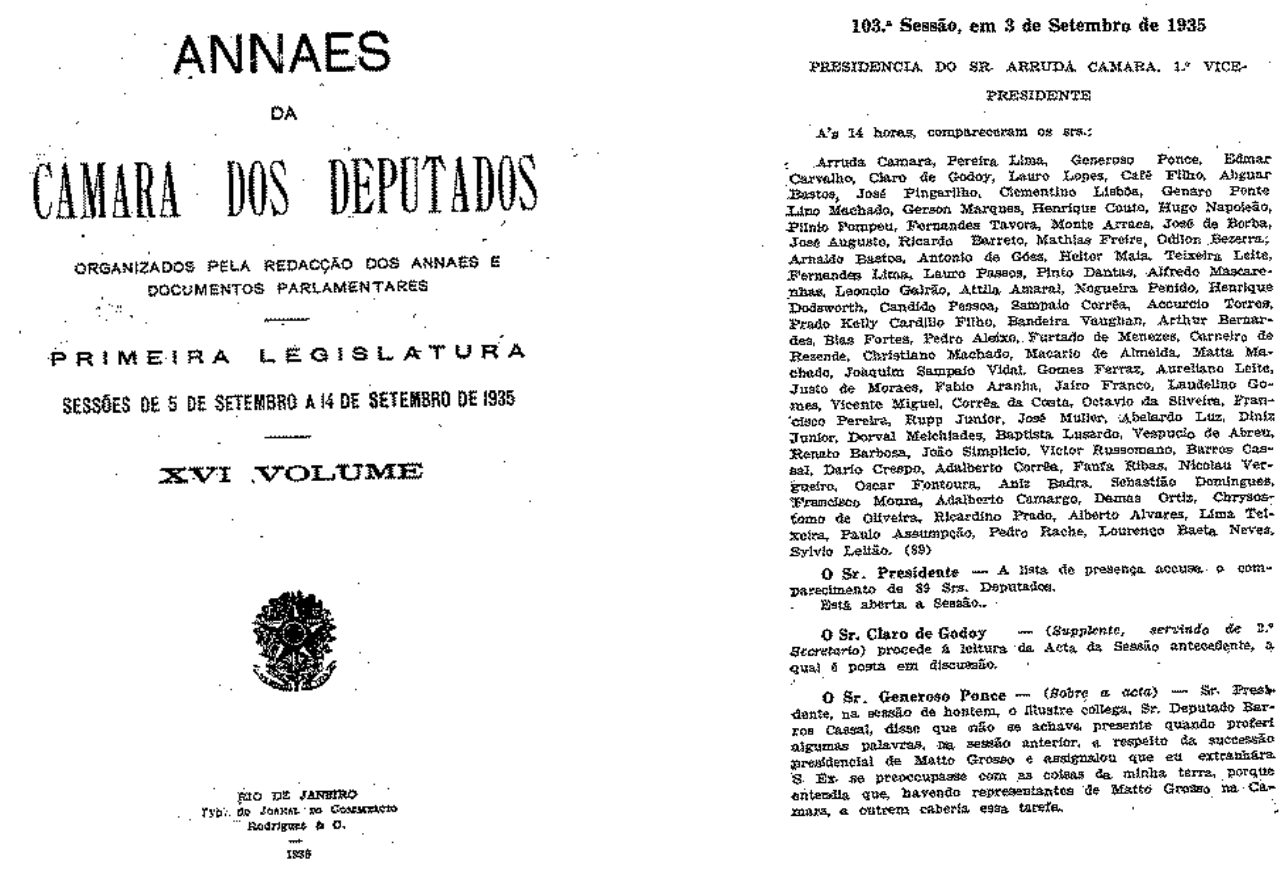

Figura 7.1. Exemplo de páginas das atas de sessões parlamentares.

Fonte: Anais da Câmara dos Deputados, v. XVI, set/1935.

Uma vez que a questão central dos debates acerca do Tratado de 1935 era justamente a da oportunidade ou não de sua ratificação pelo Congresso Nacional - ato necessário para que o Tratado tivesse vigência, segundo a constituição -, foi justamente ai, no plenário da Câmara dos Deputados, o lugar onde foram travados os maiores e mais significativos embates entre seus defensores e opositores. Além disso, foi através da análise das atas das sessões parlamentares, que a maior riqueza de detalhes acerca das ideias defendidas por cada lado pode ser encontrada na documentação. Tal análise possibilitou, assim, uma ampla caracterização dos grupos em disputa, de suas concepções e projetos, e permitiu-nos explorar em profundidade as questões propostas para o presente trabalho. Portanto, este capítulo pode ser considerado o núcleo da presente dissertação e forneceu o principal embasamento documental para nossas conclusões. 


\subsection{Definições: Como entender a conformação dos grupos no debate?}

Durante o debate na Câmara dos Deputados, destacaram-se alguns participantes mais ativos nas sessões parlamentares do ano de 1935 que trataram da ratificação do Tratado. ${ }^{218}$ Suas falas apresentam o conteúdo discursivo mais rico para as finalidades da presente investigação. Houve ainda intervenções breves de vários outros membros da casa, porém, tais manifestações foram pontuais, em contraste com as longas exposições de motivos que caracterizaram as falas dos principais debatedores. Além disso, as ideias por eles expostas definiram as controvérsias centrais e tenderam a ser reproduzidas pelos seus pares. Daí nossa opção por um enfoque mais detalhado nos indivíduos mais atuantes e representativos. Os "atores menores", porém, foram também devidamente considerados em nossa análise sobre a conformação dos grupos envolvidos no debate.

A Câmara dos Deputados havia sido formada a com as eleições para a Assembleia Constituinte de 1933, a qual elaborara a constituição promulgada no ano seguinte. Os deputados eleitos viriam então a tomar posse em maio de 1935 para a legislatura corrente à época do Tratado. Era composta, além dos 214 deputados eleitos pelo voto direto da população, por 40 representantes classistas, indicados por sindicatos dos trabalhadores e patrões de cada setor econômico.

Comecemos pelos participantes que se manifestaram abertamente contra a ratificação do Tratado. Entre eles se destacaram Antônio de Góes, Hugo Napoleão, José Bias Fortes, João Gomez Ferraz, Octavio Mangabeira, Euvaldo Lodi, Paulo Assumpção, Roberto Simonsen e Vicente Galliez. Em nossa análise, entre os mais ativos opositores do Tratado na Câmara, dois grupos principais puderam ser delineados, em função de seus vínculos de classe, fração, ou pertinência a grupos políticos significativos no cenário político da década de 1930 .

De um lado, aparecem claramente os representantes classistas dos empregadores industriais, liderados por Roberto Simonsen, e já organizados previamente devido à sua filiação a associações de classe dos industriais, tais como o Centro Industrial do Brasil (CIB), a Federação das Indústrias do Estado de São Paulo (FIESP) e a Federação das Indústrias do Rio de Janeiro (FIRJ). Como veremos adiante, estes "representantes da indústria" se articularam a outros deputados não classistas, mas também oriundos da fração industrial, em função da defesa de interesses que percebiam como fundamentais

\footnotetext{
${ }^{218}$ Principalmente as Sessões 108, de 09/09/1935 In: Anais da Câmara dos Deputados, op. cit., v. XV, 1935; 109, de 11/09/1935 e 110, de 12/09/1935 In: Anais da Câmara dos Deputados, op. cit., v. XVI, 1935.
} 
para a proteção de uma indústria nacional em desenvolvimento. Valeram-se principalmente de argumentos econômicos de cunho protecionista e argumentos políticos de tom nacionalista. Tal grupo será aqui denominado grupo dos Industriais.

Contudo, ao contrário do que é enfatizado na historiografia existente sobre o Tratado, este grupo não foi o único que se posicionou contrariamente à sua ratificação na Câmara. Há outro grupo, composto por figuras pertinentes em sua maioria a partidos políticos oriundos da República Velha, ou seus derivados, que antes haviam sido hegemônicos, como o Partido Republicano Mineiro (PRM). Eram, portanto, membros tradicionais da elite política, opositores de Vargas e contrários aos novos grupos que haviam assumido posição proeminente após a Revolução de 1930. Tal grupo que se articulou no Congresso, sob a configuração constitucional de "minoria" parlamentar e, por vezes, identificavam-se simplesmente como membros da "oposição".

O interessante é que os argumentos deste grupo são marcados por forte cunho liberal, em termos econômicos e liberais-conservadores, com traços autoritários, no plano das ideias políticas. As ideias que expressaram no debate e que fundamentaram a sua argumentação pouco diferem daquelas apresentadas pela maioria dos defensores da ratificação do Tratado. Apresentaram-se apenas com o "sinal trocado", ou seja, tais referenciais ideológicos foram instrumentalizados para sustentar posições contrárias ao Tratado. Este grupo será aqui denominado, para a finalidade de melhor identifica-lo, de Oposição Parlamentar e Octavio Mangabeira é um de seus principais representantes.

Já quanto ao grupo que se articulou em favor da ratificação do Tratado, este pode ser definido como tendo uma composição variada, mas com predomínio de funcionários públicos e profissionais liberais. ${ }^{219}$ Há, neste grupo, alguns políticos de partidos tradicionais, da coalizão que apoiava Getúlio Vargas e membros da chamada "maioria parlamentar". Contudo, destacaram-se fortemente, por sua atuação em defesa efusiva e bastante fundamentada do Tratado, os funcionários públicos e membros de uma elite burocrática federal, tais como o diplomata Diniz Júnior, sob a liderança do representante classista dos funcionários públicos, Paulo Martins, o qual leu um extenso artigo no plenário e se envolveu em um debate direto com Roberto Simonsen.

\footnotetext{
${ }^{219}$ A maioria dos dados biográficos utilizados no presente estudo foi extraída de ABREU, Alzira A. et alii. (orgs.) Dicionário Histórico-Biográfico Brasileiro. 2a ed. Rio de Janeiro: FGV, 2001. Disponível on-line. URL: . Acessado em 21/12/2011.
} 
Manifestaram-se abertamente a favor do Tratado Agenor Monte, José Cardoso de Mello Neto, Leopoldo Diniz Junior, Carlos de Moraes Andrade, Renato Barbosa, Paulo Martins, entre outros. As ideias que fundamentaram sua argumentação são predominantemente de cunho liberal clássico em termos econômicos. Como será visto adiante, a liberalização do comércio, como meio para superar a crise, e a aproximação com os EUA são alguns dos pontos centrais. Eventuais projetos políticos, possíveis de serem identificados através dos discursos, são interesses centrais do presente capítulo.

O mais notável numa primeira análise do debate é a total ausência de participações de representantes classistas da lavoura e a tímida participação de um único representante classista dos empregadores do comércio, França Filho. Além disso, a partir de uma análise dos elementos biográfico dos parlamentares, foi possível notar que entre os defensores do Tratado, havia bem poucos deputados oriundos das elites agrárias e exportadoras brasileiras.

Esta constatação gerou o primeiro ponto de discordância em relação às interpretações da historiografia acerca do Tratado. A estranheza surge quando se coloca a questão: se o Tratado atendeu aos "interesses da agroexportação", tal como afirma boa parte da historiografia, ${ }^{220}$ por qual motivo então, os supostos representantes parlamentares dessa fração da burguesia brasileira, pouco ou quase nada participaram dessa discussão na Câmara? O seu aparente desinteresse é flagrante. Uma tentativa de aproximação para uma resposta a essa questão será o ponto focal da discussão aqui apresentada.

Devemos, por ora, ressaltar que o pecuarista Demétrio Xavier, o único dos participantes mais ativos do debate parlamentar que pode ser ligado diretamente a atividades agroexportadoras - pois era membro da Associação Rural do Rio Grande do Sul -, não explicitou sua posição, ou seja, não demonstrou qualquer apoio ao Tratado, ou empenho em levar adiante a discussão.

Pelos motivos acima expostos, este grupo será aqui denominado Elite Burocrática. Membros de tal grupo não foram os únicos a adotar esta posição, mas foram certamente os mais ativos, consistentes e significativos defensores do Tratado.

\footnotetext{
${ }^{220}$ São notáveis os argumentos de LEME, op. cit., e DINIZ, op. cit. ("os círculos cafeeiros aplaudiram a medida [o Tratado]"). Cf. Seção "O Tratado e a Historiografia", da presente dissertação.
} 
Não manifestaram explicitamente sua posição alguns participantes, tais como Carneiro de Rezende, Cincinato Braga, Daniel de Carvalho, Demetrio Xavier, Figueiredo Rodrigues, França Filho, João Neves, Victor Russomano e Wanderley Pinho. Apesar de terem participado muito ativamente dos debates, revelando por vezes certa apreensão quanto ao Tratado, jamais chegaram a propor sua rejeição. Sua composição é bastante diversa.

Quanto às formações acadêmicas, a esmagadora maioria dos deputados participantes do debate era de formação jurídica (como de resto o era a maioria da elite política brasileira de então), ${ }^{221}$ e muitos tinham, ao menos em algum momento de suas vidas, exercido a profissão de advogado. Contudo, poucos são os que tiveram esta profissão como exclusiva (ou principal) fonte de renda ao longo de suas carreiras. Advogados de carreira, como Cardoso de Mello Netto, foram em geral favoráveis à ratificação do Tratado. Havia apenas um médico e um militar entre os favoráveis.

Quanto à distribuição por região, é possível notar que a maioria dos representantes dos estados de São Paulo, Rio de Janeiro (e Distrito Federal) e Minas Gerais se posicionaram contra a ratificação do Tratado, à exceção de dois deles, Souza Leão e Agenor Monte, ligados por sua vez a partidos que apoiavam o governo. Já os deputados do Sul e Norte, em sua maioria, apoiavam o Tratado. Isto poderia nos levar a concluir que o recorte regional talvez seja uma hipótese válida para explicar os diferentes posicionamentos e a formação dos grupos no debate.

Contudo, tal conclusão pode se revelar apressada, se considerarmos mais detidamente cada caso. Quase todos os deputados da região Sudeste que se opuseram à ratificação eram industriais, classistas ou não. Já os deputados favoráveis à ratificação, provenientes dessa mesma região, eram ligados à burocracia estatal. Quanto ao Nordeste e o Sul, os principais defensores do tratado eram funcionários de carreira, ou profissionais liberais, com carreiras na política. Já os contrários ao Tratado eram em geral antigos políticos da oposição, como Octavio Mangabeira. Além disso, há diferenças de posicionamento no interior de cada estado, ou seja, o recorte regional não revelou padrões confiáveis.

Quanto à vinculação partidária, entre os representantes do Partido Republicano Paulista (PRP), apenas Gomes Ferraz se manifestou e foi contrário à aprovação do

\footnotetext{
${ }^{221}$ Cf. CODATO, op. cit.
} 
Tratado. Os membros eleitos pelo Partido Republicano Libertador (PRL), do Rio Grande do Sul, estiveram divididos. Nota-se a participação de representantes do direitista Partido Nacional Socialista, entre eles, inclusive, o único "tenente" que participou do debate na Câmara, Agenor Monte, o qual foi favorável ao Tratado.

Ao que nos parece, o recorte partidário não é em si suficiente para explicar os posicionamentos dos deputados. Primeiramente porque de certa forma se confunde com o recorte regional (quase todos os partidos políticos então existentes tinham base numa região, ou num estado específico). Em segundo lugar, porque há poucos representantes de cada partido e às vezes estes não votaram coerentemente, como é o caso dos membros do PRL.

Agora, passaremos à análise das manifestações dos representantes de cada grupo, visando identificar os seus posicionamentos, as ideias expostas e suas matrizes intelectuais. Buscaremos principalmente propor um quadro dos possíveis objetivos e projetos políticos subjacentes ao seu discurso.

\subsection{Roberto Simonsen e os Industriais}

O líder industrial e deputado classista, Roberto Cochrane Simonsen foi um dos principais protagonistas do debate acerca da ratificação do Tratado de Comércio BrasilEUA, na Câmara dos Deputados. Sua manifestação na forma de um artigo lido em plenário, fortemente contrária ao Tratado, dá o tom geral da argumentação dos líderes industriais e será analisada em maior detalhe. É uma amostra do sofisticado nível de reflexão do pensamento econômico desse intelectual orgânico da fração industrial da burguesia brasileira ${ }^{222}$. Seu discurso é pautado por argumentos protecionistas em comércio exterior, pela defesa da indústria nacional e do planejamento econômico, em âmbito interno, e da diversificação das atividades econômicas, como saída para a crise mundial.

\footnotetext{
222 Essa qualificação dada a Simonsen se respalda em BIANCHI, 2007b, op. cit. Para uma apreensão detalhada das ideias deste intelectual, recorremos à LEME, op. cit.; MAZA, Fábio. $O$ idealismo prático de Roberto Simonsen: ciência, tecnologia e indústria na construção da nação. São Paulo: Instituto Roberto Simonsen, 2004, também CEPÊDA, Vera. Limites e impasses: Roberto Simonsen e a formação da ideologia industrialista no Brasil. São Paulo: FFLCH/USP, 2003 - Tese de Doutorado. Agradecemos a inestimável contribuição do colega pesquisador, Luiz Felipe Bruzzi Curi, cujo conhecimento da obra de Roberto Simonsen e de seu pensamento econômico foi fundamental para a elaboração da presente análise.
} 
Outros membros da bancada industrial, porém, também participaram ativamente das discussões, com destaque para Paulo Assumpção, então presidente da FIESP, e Vicente Galliez. Ambos trouxeram, para leitura no plenário, extensos artigos, recheados de elementos do ideário industrialista da década de 1930. A defesa da legitimidade moral da indústria nacional, por Paulo Assumpção, foi um de seus momentos marcantes.

A seguir, faremos uma análise do conteúdo discursivo dessas intervenções, procurando localizar seus fundamentos em termos de ideias econômicas e políticas, buscando ainda compreender como estas ideias se articulavam a projetos políticos concretos.

\subsubsection{Identidades de classe e interesse nacional}

Logo no início de sua fala no plenário, em 11 de setembro de 1935, Roberto Simonsen identifica-se como "representante de uma soma de interesses ligados à produção nacional", eleito pelos sindicatos industriais brasileiros e que, portanto, seria "alheio às competições pessoais". Ainda nesse sentido, afirma "não tenho qualquer ligação ou dependência econômica, financeira, política ou social, a cujas injunções (...) podem estar subordinadas minhas convicções". 223

Dessa forma esforça-se para construir um discurso de "neutralidade", já antevendo que poderia ser tachado de "partidário" de interesses particulares. Em seguida, contudo, refere-se à "classe que represento", ou seja, a dos industriais. A contradição aparente entre o discurso universal de neutralidade e o discurso de classe parece se resolver em seguida, através da identificação dos interesses da indústria com os do país. ${ }^{224}$

Simonsen, assim como vários deputados ligados à indústria que participaram do debate, procurou associar diretamente a ideia de "interesse nacional" e os interesses da indústria nacional, ou da classe industrial. Tal associação aparece claramente em passagens de seu discurso na Câmara: "tendo em vista exclusivamente os seus altos interesses [do país], que reputo idênticos aos da classe que represento". ${ }^{225}$

Ou ainda ao recorrer a um discurso por ele proferido na FIESP (1928), para reforçar sua fala no plenário: "é patente a absoluta coincidência entre os fins que colimam os industriais e os verdadeiros interesses nacionais". ${ }^{226}$ Já no discurso de Vicente Galliez,

\footnotetext{
${ }^{223}$ Anais, op. cit., v. XVI (11/09/1935), p. 264.

${ }^{224}$ Idem, p. 264.

${ }^{225}$ Idem, p. 264.

${ }^{226}$ Idem, p. 264.
} 
a associação do interesse nacional se faz diretamente à prosperidade da indústria têxtil, mais especificamente a de camisas de algodão. ${ }^{227}$

De fato, para Simonsen, não se tratava somente de defender a produção existente, mas também de fazê-la crescer. Nesse sentido, ele exorta os colegas deputados a "colocar os interesses do país acima de suas vaidades, competições pessoais e partidárias". complementa essa posição com a afirmativa de que não era "pessoalmente prejudicado pelo tratado americano", mas que firmava posição em contrário, devido a uma postura protecionista, que todo "bom brasileiro" deveria ostentar. Dessa forma, ele se colocava como representante do interesse nacional, geral e não de algum interesse egoísta, ou particular. $^{228}$

Esse trecho denota uma mudança no pensamento de Simonsen, de preocupações mais restritas à esfera da firma, para um discurso que abrange problemas nacionais. Para Vera Cepêda, isto marca a passagem da primeira fase de produção intelectual de Simonsen para uma segunda fase, na qual ele teria passado a buscar a construção de uma hegemonia industrial no Brasil. ${ }^{229}$ Esta interpretação se coaduna à nossa hipótese acerca do posicionamento da classe industrial no debate sobre o Tratado.

\subsubsection{A Legitimidade da Indústria nacional}

Um dos elementos discursivos mais marcantes das falas de dois dos líderes industriais participantes do debate, Vicente Galliez e Paulo Assumpção, é a construção da ideia da legitimidade da indústria nacional. Tal preocupação se justificava na medida em que a fração industrial vinha há muito sofrendo ataques de políticos e intelectuais ligados às frações agrárias e mercantis, em função de oposições de interesses que por vezes se estabeleceram quanto a certas questões de política econômica. ${ }^{230}$ Tais ataques, de cunho moral, visavam deslegitimar suas reivindicações políticas - tais como a de uma política de proteção alfandegária. Consistiam, em geral, em considerar boa parte da indústria local como "artificial", ou em atacar os "privilégios" da Indústria.

A fim de avançar suas demandas e, ao mesmo tempo, construir um novo consenso em torno de seus projetos políticos, líderes e intelectuais ligados a essa fração procuraram

\footnotetext{
${ }^{227}$ Anais, op. cit., v. XVI (10/09/1935), p. 199.

${ }^{228}$ Idem, p. 298.

${ }^{229}$ Essa periodização é proposta por Cepêda, que a situa, em 1928, com a fundação do CIESP e o discurso proferido por Simonsen nesta ocasião. Ver CEPÊDA, op. cit..

${ }^{230}$ Contudo, em geral, as diferentes frações da classe capitalista brasileira não tinham ainda interesses radicalmente antagônicos. Cf. LUZ, op. cit.
} 
com afinco reconstruir as representações sobre a indústria. Galliez, por exemplo, afirmou no plenário: "Não há indústrias fictícias no Brasil, nem em parte alguma. Toda atividade que incorpora riqueza ao patrimônio nacional é legítima". ${ }^{231} \mathrm{E}$ "convém salientar que o Brasil possui produção industrial tão grande quanto a produção agrícola". ${ }^{232}$

O apelo, com forte carga moral, para que a indústria nacional fosse colocada em "pé de igualdade" com os demais setores, foi a contribuição mais relevante de Paulo Assumpção para o debate:

Quero apenas opor, em nome dos industriais, um basta à arrogância impertinente dos que nos combatem (...). Não somos traficantes de coisas ilícitas, nem entraves ao desenvolvimento de qualquer outra fonte de produção (...), exigindo para nós o respeito igual aos que mais o merecem. Já estamos cansados em consentir que sobre nossas costas extravasem as culpas e as consequências dos erros que não praticamos. Se não soubemos realizar o milagre de industrializar o Brasil sem o sacrifício de uma tarifa protecionista, podemos, entretanto, alinhar aos olhos da Nação, cifras que, num período de quinze anos decuplicaram o valor de nossa produção (...). Essas cifras irrespondíveis e impressionantes dão-nos o direito que ora estamos exigindo. ${ }^{233}$

Como se pode observar na passagem acima, Assumpção toma para si a defesa moral da indústria. O crescimento do produto seria o argumento legitimador, pois invalidaria a tese de que as indústrias nacionais seriam meramente parasitárias. Trata-se, como foi dito, de parte de um esforço para forjar um novo consenso acerca da economia brasileira que reservasse um novo - e mais relevante - papel para a indústria nacional.

\subsubsection{Posições sobre o Tratado}

Em várias passagens de seu discurso no plenário da Câmara, Simonsen faz uma crítica aos tratados baseados na cláusula de nação mais favorecida, que deixaria o país "amarrado" em termos de sua política comercial, dado que quaisquer vantagens negociadas com um determinado país teriam que ser imediatamente estendidas aos demais (já então haviam mais de 30 tratados com esta cláusula). Preocupa-se, portanto, com a manutenção da soberania e da independência econômica, principalmente em tempos de crise. ${ }^{234}$ Critica muito o sigilo da negociação, no que é secundado por Galliez.

Simonsen expressa um juízo bastante severo sobre o Tratado, considerando-o mal feito. Traz implícita uma crítica à conduta dos agentes diplomáticos do governo, que teriam conduzido uma negociação falha, sem levar em conta interesses fundamentais da

\footnotetext{
${ }^{231}$ Anais, op. cit., v. XV (09/09/1935), p. 142.

232 Idem, p. 149.

${ }^{233}$ Anais, op. cit., v. XVI (10/09/1935), p. 212.

${ }^{234}$ Idem, p. 274.
} 
produção nacional. O contraponto é feito com a representação estadunidense, a qual, tendo clareza das diretrizes de sua política externa, havia resguardado o interesse estratégico fundamental dos EUA, no caso: a liberação dos fluxos comerciais internacionais. Simonsen firma essa posição, expressamente: "assinamos um tratado em que prevaleceram as diretrizes da política norte-americana". 235

\subsubsection{Prejuízos para a Indústria}

Contudo, o eixo de sua crítica é a ideia de que o Tratado acarretaria grandes prejuízos para a indústria nacional, agravando a instabilidade conjuntural da economia brasileira:

É um tratado desigual (...). E nos é prejudicial porque vem afetar várias atividades implantadas no Brasil (...). A diretriz estabelecida em tal tratado agrava as condições da instabilidade em que vivemos (...) em troca da consolidação de direitos ou em troca de favores já existentes, sacrificamos atividades dentro do país. ${ }^{236}$

Uma questão imediatamente correlata aos prejuízos para a indústria seria a dos efeitos no emprego e para a classe operária que se formava. Simonsen ainda traz uma dimensão nova: o risco de se criar um clima de hostilidade com os EUA: "Toda indústria prejudicada, todo operário que se vê sem trabalho em decorrência desse tratado, todos esses ficam com animosidade contra os Estados Unidos". ${ }^{237}$ E para Simonsen tal prejuízo poderia certamente ter sido evitado por uma negociação bem conduzida: "Não precisávamos sacrificar indústria alguma, operário algum, para fazer um tratado que favorecesse o Brasil. Poderíamos conceder outros favores". 238

No mesmo sentido, se manifesta Vicente Galliez, afirmando que o Tratado não poderia ser aprovado, devido aos:

(...) golpes mortais nele contidos contra o trabalho nacional (...). Numerosas seriam as fábricas condenadas à paralização, milhares serão os operários que ficarão ameaçados de desemprego (...). [As] consequências não poderão ser previstas, agravando de forma acentuada a delicada crise que estamos atravessando. ${ }^{239}$

\footnotetext{
${ }^{235}$ Idem, p. 291.

${ }^{236}$ Idem, p. 299.

${ }^{237}$ Anais, op. cit., v. XV (09/09/1935), p. 135.

${ }^{238}$ Idem, p. 135.

${ }^{239}$ Anais, op. cit., v. XVI (10/09/1935), p. 211.
} 
Simonsen critica ainda a adoção da cláusula de nação mais favorecida, já que esta seria um "instrumento a serviço da manutenção do predomínio dos países industriais": "a cláusula de nação mais favorecida foi imaginada pelos países industriais que, com ela, visavam à conquista de novos mercados". ${ }^{240}$ Aqui se torna evidente o caráter do nacionalismo econômico, que já se delineava nos projetos industrialistas do período. Uma vez que tal cláusula estaria sendo abandonada então pela maioria dos países, o Brasil estaria contrariando a tendência histórica em direção ao protecionismo com a assinatura do Tratado. ${ }^{241}$

\subsubsection{Política econômica e comercial: Planejamento e protecionismo}

Simonsen defende, em inúmeras passagens, uma atuação planejadora e reguladora efetiva do Estado no âmbito do comércio exterior. Propõe a criação de um "órgão coordenador", a ser denominado "Instituto Nacional de Exportação", com a finalidade de coordenar os saldos de balança comercial com o pagamento aos credores externos. Também orientaria a política de exportação a partir de um conselho, ocupado por cidadãos de "notória capacidade" e "perfeitos conhecedores dos mercados internacionais". ${ }^{242}$

A ação deste órgão deveria promover uma política de estímulo às atividades econômicas internas, consubstanciada, entre outras medidas, na adoção, ao mesmo tempo, de uma política de liberdade para as exportações e de certa restrição para as importações, com um escala de prioridades (pela ordem: matérias primas para indústria nacional, trigo e combustíveis, farmacêuticos, elementos para o "aparelhamento econômico"). ${ }^{243}$

A ideia é acompanhada de um clamor pela adoção de diretrizes claras em política econômica internacional: "O que é preciso é (...) adotarmos desassombradamente diretrizes claras em matéria de política econômica", dando a entender que até então não existiam. E tais diretrizes deveriam contemplar um novo papel para o Brasil na economia mundial. ${ }^{244}$ Tais diretrizes ainda deveriam variar de acordo com a conjuntura, mas deveria haver um princípio permanente que subordinaria os demais objetivos: uma orientação nacionalista.

\footnotetext{
${ }^{240}$ Anais, op. cit., v. XVI (11/09/1935), p. 304.

${ }^{241}$ Idem, p. 304.

242 Idem, p. 273.

243 Idem, p. 274.

${ }^{244}$ Idem, p. 264.
} 
Tal posição é apoiada por Galliez, o qual reivindica a elaboração de uma "tarifa inteligentemente protecionista", permitindo a entrada facilitada de matérias primas e insumos para a indústria. Quanto à política tarifária, Galliez ainda estabelece uma oposição entre a "interpretação alfandegária" da lei de tarifas e o "interesse dos produtores". Por trás dessa oposição há uma oposição de objetivos e interesses: o do governo (seus agentes), em obter renda e o dos industriais, em obter proteção. ${ }^{245}$

Visando definir os objetivos mais específicos à política comercial, Simonsen delineia alguns dos elementos centrais de sua proposta. A política comercial deveria ser conduzida de tal forma que viesse a intensificar economia interna, amparar a venda do café e de outros produtos de exportação, visando obter matérias primas para a indústria e seguindo o caminho da coordenação e do planejamento. ${ }^{246}$

Outro objetivo central seria a obtenção de saldos comerciais favoráveis, a fim de que se acumulassem divisas, muito necessárias em um contexto de escassa liquidez, tanto para fazer face aos compromissos externos do Brasil - cujo atraso no pagamento dificultava a atração de investimentos e a obtenção do crédito externo, gerando tensões diplomáticas crescentes -, quanto para viabilizar a importação de bens de capital para a indústria nacional. ${ }^{247}$

\subsubsection{Questões econômicas}

Uma das questões centrais presentes na intervenção de Simonsen é a da relação entre os setores das atividades econômicas nacionais, a agricultura e a indústria, sua importância relativa para a constituição de uma economia nacional forte e para a superação da crise. A argumentação apresentada no debate demonstra que muito longe de ser contrário a uma política de estímulo à agricultura, Simonsen defendia um crescimento equilibrado:

O tipo ideal de nação normal (...) é aquele em que se equilibram e harmonizam os vários ramos das atividades humanas. E entre nós não há motivo algum para antagonismos das duas grandes classes, agricultura e industrial, cujas atividades se completam e cujo progresso se reflete o de uma na outra, de maneira harmônica e simultânea, em benefício da grandeza do país (...), não estamos isolados no mundo ao adotarmos uma política agroindustrial. É a política generalizada da maioria dos povos. ${ }^{248}$

\footnotetext{
${ }^{245}$ Anais, op. cit., v. XVI (10/09/1935), p. 190.

${ }^{246}$ Idem, p. 304.

${ }^{247}$ Anais, op. cit., v. XV (09/09/1935), p. 133.

${ }^{248}$ Anais, op. cit., v. XVI (11/09/1935), p. 281.
} 
Nota-se de passagem a construção da ideia de que havia uma coincidência de interesses entre indústria e agricultura. A política econômica propugnada por ele, portanto, não é "industrial" em oposição a uma "política agrícola" e sim uma política híbrida, que expressa sua visão de complementaridade de interesses. Fica claro que Simonsen não localiza nos interesses da agroexportação o "adversário" no debate acerca do Tratado.

Seu contraponto a certas teses então vigentes ia antes no sentido de questionar as posições que defendiam a precedência absoluta da agricultura na economia nacional:

O café está em superprodução e (...) sustentamos artificialmente suas cotações internas (...) constituindo cerca de $70 \%$ da nossa exportação, não podemos esperar que $70 \%$ da população viva em torno do comércio do café (...) [a] população cresceu muito rapidamente para que se possa esperar que a nossa civilização repouse unicamente nessa monocultura. ${ }^{249}$

Simonsen emprega um argumento de cunho "malthusiano" para criticar a forma de inserção "tradicional” do Brasil na economia mundial. A posição de produtor primário não poderia mais prover recursos para sustentar uma população crescente, em ritmo mais rápido que o da produção de alimentos. Mas há subjacente ao discurso, também uma questão política: o realce da suposta demanda urgente de "elevação do padrão de vida" pode ser visto como um indício de percepção de uma tensão social latente. ${ }^{250}$

Simonsen representa a industrialização, quase como um "destino manifesto". A grandeza nacional não viria da agricultura somente, devido a determinações naturais e históricas: "A instalação da indústria no Brasil tinha que surgir como um imperativo inelutável na história da economia brasileira. A nossa produção agrícola, pela sua natureza, qualidade e quantidade, não pode por si só fornecer os elementos de vida, de acordo com as necessidades crescentes da população". ${ }^{251}$

\subsubsection{O “caráter” do Brasil}

Simonsen se esforça por construir uma nova representação acerca do caráter da economia nacional, a qual, acreditamos, faz da construção de um projeto hegemônico para a fração industrial da burguesia brasileira. Isto pode ser verificado em sua afirmação

\footnotetext{
${ }^{249}$ Idem, p. 280.

${ }^{250}$ Idem, p. 281.

${ }^{251}$ Idem, p. 278.
} 
de que "nos tratados comerciais, devemos afastar a ideia de considerar o Brasil apenas país agrícola". ${ }^{252}$ Simonsen deixa transparecer sua preocupação em contrapor a tese, ainda então muito forte, de que o Brasil se caracterizaria economicamente por uma "vocação agrícola". No seio de uma disputa pela condução da política econômica nacional, que passaria necessariamente por um esforço em prol da construção de um novo consenso, em nível político e ate cultural, é central a disputa pela definição de uma "identidade econômica" nacional para o Brasil.

Outro elemento de seu projeto político é atribuir crescente relevância ao mercado interno como polo dinâmico:

[O Brasil], dotado de clima diferente, produzindo mercadorias de menor procura (...) não pode fazer sua prosperidade baseado exclusivamente na divisão do trabalho necessária aos seus negócios internacionais (...). Daí a relevância dos interesses econômicos ligados ao mercado interno. ${ }^{253}$

A postura protecionista é outra marca indelével do discurso de Simonsen e de outros líderes industriais no debate. Mas ela é frontalmente contraposta pelos defensores do Tratado, como o burocrata Paulo Martins. Os argumentos, de cunho liberal clássico e livre-cambista destes adversários, apelam em geral ao "senso comum", dando a entender que a posição que então soaria mais heterodoxa era a dos industrialistas. No entanto, contraditoriamente, ambas as partes reconhecem a ascensão de uma "tendência protecionista" geral no mercado mundial. Corroborando essa ideia, Simonsen afirma: "No Brasil, tem-se medo de dizer que é protecionista. Eu tenho a coragem precisa para me declarar protecionista convicto (...) sou protecionista como bom brasileiro". ${ }^{254} \mathrm{O}$ "medo de dizer que é protecionista" pode sugerir um indício da força do pensamento liberal.

Talvez a questão de fundo mais relevante, porque permeia todo o debate, definindo as posições em jogo, é esta, que contrapõe o protecionismo à defesa do livre comércio. De fato, entre essas posições polares pode haver muita variação num espectro que vai desde uma proposta de defesa irrestrita da indústria nacional, até posições de abertura completa da economia. Na conjuntura de meados da década de 1930, é possível identificar uma tendência mais geral às posturas defensivas, dadas as circunstancias do mercado mundial e as práticas de política econômica generalizadas no período. Ainda

\footnotetext{
${ }^{252}$ Anais, op. cit., v. XV (09/09/1935), p. 125.

${ }^{253}$ Anais, op. cit., v. XVI (11/09/1935), p. 268.

${ }^{254}$ Idem, p. 298.
} 
assim, é possível identificar um amplo leque de posições de cunho liberal, no debate em questão, e é contra essas posições que Simonsen se define em favor do protecionismo.

Nesse sentido, sua posição se define também por oposição a um liberalismo econômico de viés clássico e ao livre-cambismo, representado como uma política forjada pelas nações industriais e "vendida" para os países periféricos como se fosse a única alternativa possível. Para Simonsen e outros industriais envolvidos no debate, seria ao contrário, uma política que somente favorece as nações industriais, em detrimento dos países mais "fracos", porque menos industrializados. ${ }^{255}$

Pode-se depreender da passagem acima, a percepção de que se estaria presenciando transformações estruturais na economia mundial, notadamente o processo de industrialização em países periféricos, que legitimaria a ação protecionista. Isto se deve ao fato de que o modo de inserção tradicional na economia mundial, e as políticas econômicas que dele derivavam, não mais se sustentariam nessa "nova situação". 256

A crítica de Simonsen ao liberalismo econômico, contudo, não se traduz numa crítica à tradição liberal num sentido mais amplo. Em seus termos, estabelece uma cisão entre a tradição liberal do pensamento político e o liberalismo econômico clássico, como quando critica a "lamentável interdependência que se quer estabelecer, por preocupações doutrinárias entre o liberalismo político e as teorias livre-cambistas". 257

Num viés mais político, o liberalismo econômico, adotado por inclinações "doutrinárias", teria sido fator de promoção da luta de classe: "E nós aqui vivemos adotando o liberalismo pregado para uso externo, combatendo nossas atividades econômicas, promovendo luta de classe". ${ }^{258}$ Verifica-se a crítica ao liberalismo como um conjunto de ideias que viriam "de fora", pregadas pelos países adiantados apenas para o consumo dos outros.

A luta de classe aparece no discurso, associada ao prejuízo a setores da economia nacional. Pode ao mesmo tempo referir-se a uma luta entre frações da classe dominante, ou a uma percepção de uma tensão social mais ampla, envolvendo as classes populares. Nos termos de seu discurso, parece esposar preceitos do liberalismo político, notadamente o respeito aos direitos do indivíduo. Porém, o próprio indivíduo aparece subordinado a uma realidade superior, a Nação, vista como sujeito de direitos políticos próprios.

\footnotetext{
255 Idem, p. 294.

${ }^{256}$ Idem, p. 294.

${ }^{257}$ Idem, p. 266.

${ }^{258}$ Idem, p. 297.
} 
Outro aspecto muito interessante de seu pensamento econômico é a forma pela qual se concebe o papel do capital externo para a promoção da industrialização e para o equilíbrio macroeconômico. A entrada de capitais externos é vista como necessária para manter o equilíbrio cambial. ${ }^{259}$ A relação entre o capital interno e externo, a economia nacional e a política comercial é mais bem explicitada abaixo:

\begin{abstract}
A solução que se nos depara é, portanto, a de procurar alianças entre os interesses estrangeiros representados por seus capitais no Brasil e os elementos nacionais do trabalho. Para a solução do problema das transferências é, enfim, mister ligar o problema de nossas exportações ao da satisfação dos nossos compromissos com o exterior. Precisamos (...) esclarecer aos nossos credores estrangeiros que (...) só pudemos fazer, nos últimos tempos, a remessa dos serviços de nossas dividas externas com os recursos proporcionados pelo afluxo de capitais para o país. ${ }^{260}$
\end{abstract}

Parece assim pretender estabelecer uma nova relação com o capital externo, frente à escassez de liquidez internacional: atrair capitais, vinculando este fluxo ao pagamento das dívidas passadas. Parte do pressuposto de que é possível uma coincidência de interesses e não um antagonismo entre capitais externos e internos. A formação de capital interno é vista como pré-requisito para a independência da economia nacional. E é o influxo de capital externo que supriria a deficiência do capital interno e poderia propiciar o crescimento das atividades internas, necessário, por sua vez, para a formação futura de um capital nacional. ${ }^{261}$

\title{
7.2.8. Visões sobre a crise
}

A crise econômica mundial e a Grande Depressão constituem o pano de fundo de todo o debate. Elemento presente e profundamente sentido, tanto por Simonsen, quanto por seus interlocutores, configura o campo no qual as questões em jogo e a polarização política se definem concretamente. Importante, portanto, é a definição mais clara de como esta era percebida, entendida e explicada. Atribui a crise ao "desequilíbrio da produção relativamente ao consumo", afirmando que "há superprodução de muitos artigos pelo mundo afora". ${ }^{262} \mathrm{O}$ fechamento geral dos mercados aparece como o efeito e a não causa da crise. E teria sido o de significado mais grave para o Brasil. ${ }^{263}$

\footnotetext{
${ }^{259}$ Idem, p. 280.

260 Idem, p. 271.

${ }^{261}$ Idem, p. 280.

${ }^{262}$ Anais, op. cit., v. XV (09/09/1935), p. 123.

${ }^{263}$ Anais, op. cit., v. XVI (11/09/1935), p. 288.
} 
Porém, ao final aponta, a partir das características próprias da inserção do Brasil na economia mundial, as possibilidades de sua superação. "No Brasil, não temos, felizmente, desocupados. Podemos constituir um grande mercado interno para nossas próprias atividades". ${ }^{264}$ Daí, mais uma vez, é legitimada a adoção de uma política econômica focada na dinamização do mercado interno e na superação da condição de exportador primário e importador de manufaturados.

Transparece ao final a percepção de transformações profundas na relação de forças entre as Nações, em termos de política externa, bem como nas relações econômicas, forjando-se uma nova divisão internacional do trabalho:

Há um século atrás, a Inglaterra era o centro econômico do mundo; em torno dela giravam os interesses econômicos universais. Surgiram depois outros centros econômicos: a França, a Alemanha, os Estados Unidos (...) veio a guerra e como uma de suas consequências uma nova divisão do trabalho. Estabeleceram indústrias em países onde dantes não existiam. ${ }^{265}$

Pode-se dizer que Simonsen percebia, em seus próprios termos, o que poderíamos denominar um deslocamento do eixo, uma "recentragem", ou ainda o nascimento de um novo "ciclo hegemônico", na linguagem teórica de Giovanni Arrighi. ${ }^{266}$ Simonsen, contudo, ainda não situa o centro de forma inequívoca nos EUA, antes percebe a existência de vários centros. ${ }^{267}$

\subsubsection{Questões políticas}

Simonsen, ao longo de sua participação no debate parlamentar sobre o Tratado de 1935, assume uma postura firme de crítica à atuação dos agentes estatais nas negociações e em termos da condução política econômica externa mais geral. Referindo-se às negociações do Tratado, afirma que "Competia ao governo do Brasil apresentar-se também com uma política comercial bem orientada em que se assegurasse o absoluto respeito à vida das atividades econômicas já instaladas no país", 268

No debate transparece também uma crítica à própria relação entre a cúpula do Estado e suas instâncias decisórias subordinadas. A burocracia é vista como dependente e vinculada a um Estado autoritário. Simonsen, por exemplo, questiona a "autonomia"

\footnotetext{
${ }^{264}$ Idem, p. 298.

265 Idem, p. 298.

${ }^{266}$ ARRIGHI, op. cit.

${ }^{267}$ Idem, p. 300.

268 Idem, p. 291.
} 
decisória dos funcionários públicos. A determinação, em favor do Tratado, teria partido "de cima", ou seja, da cúpula do governo. ${ }^{269}$

Ao longo de suas falas no plenário, Simonsen procede à construção discursiva de uma associação entre economia e política: a estabilidade nacional e a própria unidade da Nação estariam em jogo na resolução dos problemas econômicos: "o problema que permanentemente se nos depara com o caráter de maior gravidade (...) [e] repercussões na estabilidade social e na conservação da unidade nacional é o econômico". ${ }^{270}$

Mais do que isso, as questões econômicas tem forte vinculação com a política. Notavelmente no que concerne a questões de soberania e autodeterminação nacionais: "A Existência do Estado independente pressupõe a coexistência da economia independente". ${ }^{271}$

\subsubsection{Matrizes intelectuais}

Entre os vários autores que cita, em seu discurso, para respaldar sua posição, encontramos em destaque Adam Smith, o qual elogia como o mais rico dos pensadores "liberais". Ele também instrumentaliza as ideias desse pensador, ao evocá-lo para reforçar a ideia de que a nação deve ser rica para ser forte, e forte para ser independente. Cita também Fredric List, para a crítica do livre-cambismo e Adolph Wagner, em função de seu conceito de economia nacional.

\subsubsection{Um projeto nacional}

Acreditamos que, a partir dos discursos dos "Industriais", no debate parlamentar acerca do Tratado, é possível delinear aspectos de um projeto mais abrangente, de alcance nacional. Um desses elementos pode ser obtido a partir da fala de Simonsen, o qual recorreu no plenário a trechos de seu discurso, proferido na FIESP (1928):

O aumento da capacidade de consumo do país representará a abertura de um considerável mercado para os industriais brasileiros; o consumo e a produção, crescendo harmonicamente aumentarão a riqueza, trarão o engrandecimento do país, o bem estar e a tranquilidade da sua população, que poderá, com calma e a serenidade precisas, resolver então todos os demais problemas nacionais, que são de ordem secundária. ${ }^{272}$

\footnotetext{
${ }^{269}$ Anais, op. cit., v. XV (09/09/1935), p. 128.

${ }^{270}$ Anais, op. cit., v. XVI (11/09/1935), p. 265.

${ }^{271}$ Idem, p. 266.

${ }^{272}$ Anais, op. cit., v. XVI (11/09/1935), p. 264.
} 
Transparece a ideia de que o aumento da capacidade de consumo (nível de renda média) da população é a chave para o engrandecimento da riqueza nacional. $\mathrm{O}$ ponto central estria no desenvolvimento de um mercado interno pujante, que crescesse no ritmo da oferta. Daí, o que interessa aos industriais (um mercado para sua produção) pode ser associado a um projeto para o Brasil. Tal projeto se associa a uma nova forma de inserção na economia mundial, pautada pela transformação do Brasil em produtor industrial, em alguma medida, mais voltado para o mercado interno.

\subsection{Octávio Mangabeira e a Oposição Parlamentar}

O engenheiro, acadêmico e jornalista baiano Octávio Mangabeira teve longa carreira política, tendo chegado a ocupar o cargo de Ministro das Relações Exteriores do governo de Washington Luís (1926-1930). Eleito, em 1934, deputado federal pela Bahia com o apoio da coligação entre a Liga de Ação Social e Política (LASP) e o Partido Republicano Democrata (PRD), tornou-se um dos líderes do bloco parlamentar de oposição a Vargas. Sua atuação no Congresso se destacou especialmente nas ocasiões em que o governo tomava medidas consideradas pela oposição como crescentemente repressivas e fortalecedoras do Executivo.

Sua crítica ao Tratado é fundamentada no argumento de que se tratava de um acordo desigual, prejudicial aos interesses do Brasil, e que isto se devia à inépcia dos agentes do governo e ao fato de estes terem realizado as negociações em sigilo e sem consultas à sociedade. O tom é sempre o da crítica liberal ao governo Vargas, ao seu autoritarismo e superdimensionamento do poder Executivo. Destaca-se também em sua fala, a preocupação com as rendas aduaneiras, as quais, segundo ele, e ao contrário do que afirmam os defensores do Tratado, seriam reduzidas devido à baixa de tarifas, prejudicando as receitas do Estado e o equilíbrio das contas púbicas.

Mangabeira se vale de concepções liberais em economia e em nenhum momento questiona a validade do livre-comércio, nem a forma de inserção do Brasil na economia mundial. O mesmo vale para outros participantes do mesmo grupo. Também não faz criticas aos Estados Unidos. Ao contrário, tal como é comum para todos os participantes do debate, declara sua admiração por aquele país. Também não se opõe a uma aproximação comercial, mas questiona a forma com que o governo a estaria buscando.

Como se pode notar, o arcabouço conceitual e as ideias de Mangabeira - e de outros deste grupo, tais como Gomes Ferraz e Bias Fortes - não diferem em sua essência 
daqueles dos defensores do Tratado no debate. Apenas se apresentam com "sinal trocado", ou seja, argumentos semelhantes são invertidos para defender uma posição contrária. Assim, por exemplo, onde o Tratado é visto como benéfico para a arrecadação aduaneira, para Mangabeira é prejudicial e assim por diante.

Acreditamos que, ao contrário do grupo dos "Industriais", o posicionamento desse grupo não é fundado em diferenças substanciais quanto às concepções sobre a política econômica, nem se sustenta em projetos políticos claramente diferenciados. O que os caracteriza é antes o fato de representarem agremiações da antiga elite política da Primeira República, que haviam perdido o controle dos postos chave no aparelho de Estado com a crise da hegemonia das frações de classe regionais anteriormente dominantes, e lutavam para recuperar o terreno perdido. Por este motivo, optamos por denomina-la Oposição Parlamentar. Passemos então à análise de alguns elementos presentes em suas manifestações.

\subsubsection{Posições sobre o Tratado}

Suas críticas ao Tratado se direcionam contra o sigilo da negociação ${ }^{273}$ e devido à percepção de que se tratava de um Tratado desigual e assimétrico: "vamos dar, no convenio, muito mais do que vamos receber (...). Os produtos beneficiados por concessões dos EUA representariam uma fração mínima das exportações". ${ }^{274}$ Contudo, o argumento central parece ser a preocupação com a defesa das rendas aduaneiras do Estado. Assim, ele denuncia as repercussões negativas "de ordem fiscal, poder-se-ia dizer financeira, visando à arrecadação, que em uma hora como esta, de imenso desequilíbrio orçamentário, evidentemente se reveste de uma importância excepcional". ${ }^{275}$ Trata-se de uma preocupação de viés ortodoxo com o equilíbrio das contas públicas:

Estando o Brasil com um déficit formidável, como pode a comissão de finanças dar o seu voto à aprovação de um tratado que diminui os direitos de alfândega e, portanto, reduz a estimativa da reserva (...) será, acaso, a ocasião oportuna para firmarmos tratados que desfalcam assim, sensivelmente, as rendas federais. ${ }^{276}$

Há um elemento associado à ideia de desigualdade do Tratado, a implicação de subordinação e perda de autonomia política que ele traria. Denuncia a falta de bom senso na submissão ao "interesse do mais rico". Assim, no Tratado, o Brasil teria se colocado

\footnotetext{
${ }^{273}$ Anais, op. cit., v. XVI, (10/09/1935) p. 219.

${ }^{274}$ Idem, p. 225.

${ }^{275}$ Idem, p. 219.

${ }^{276}$ Idem, p. 225-6.
} 
na situação de "protegido" (mais própria das colônias), pondo em risco sua autonomia. Traçando uma analogia entre a nação e o indivíduo, Mangabeira trata a questão sob um viés moral. $^{277}$

\subsubsection{A vocação agrária e a inserção do Brasil na economia mundial}

Mangabeira endossa a visão tradicional e qualifica o Brasil como "país exportador". Dá prioridade à retomada das vendas de café. Contudo, apesar de considerar prioritário este objetivo, afirma não acreditar que o Tratado seja o caminho para esta retomada. Para ele, o comércio livre deve ser preservado, mas não à custa da subserviência a qualquer país estrangeiro. ${ }^{278}$

Porém, em termos de objetivos de política externa, demonstra ser bastante favorável a uma aproximação com os EUA:

Toda política exterior do Brasil, que não tiver como um dos seus fundamentos a manutenção das relações as mais cordiais e mais sólidas (...) com os Estados Unidos será política de contrassenso e absurdo (...). Nosso dever é dar desenvolvimento a essa política de União cada vez mais estreita (...) com a grande democracia norte-americana. ${ }^{279}$

Para Mangabeira, "A crise no Brasil é uma grande crise moral". Atribui à má gestão das contas públicas o grosso das dificuldades econômicas. Aponta como causas o déficit, a moratória, as emissões do Banco do Brasil, a ameaça de novas emissões, a dissipação dos congelados, o confisco da exportação, a degradação da moeda, "em uma palavra: a derrocada". Para solucioná-la, preconiza a moralização da política econômica (o que parece significar torna-la mais "ortodoxa") e a reforma da administração, bem como a ênfase na recuperação dos mercados para o café. ${ }^{280}$

\subsubsection{Posições Politicas}

Com relação ao Governo Vargas, o tom de suas críticas é ácido e de cunho moralista. A ineficácia, a falta de organização, a falta de transparência, são características atribuídas ao governo. Qualifica 1930 como "o ano da desgraça", marcando sua oposição ao regime, através do repúdio ao seu ato fundador. Para ele, "a maneira por que foi negociado o tratado revela que o país não tem governo". Critica a "ausência de

\footnotetext{
${ }^{277}$ Idem, p. 216.

278 Idem, p. 216.

${ }^{279}$ Idem, p. 216.

${ }^{280}$ Idem, p. 229.
} 
organização", por não se ter instituído ou aparelhado os órgãos dos agentes negociadores dos tratados comerciais, o que não permitiria confiar nos resultados de suas ações. ${ }^{281}$

Tece ainda críticas à atuação do Executivo, que estaria deixando de consultar o órgão técnico competente (CFCE) e os ministérios relacionados. Tal executivo estaria inflado por órgãos incapazes de decidir e, portanto, inúteis. É uma crítica cheia de viés moral, mas denota repúdio a um poder central "excessivo":

Funciona com certa pompa (...) um órgão recém-criado que se chama Conselho Federal de Comércio Exterior do Brasil (...) o próprio Chefe do Governo, quando se sente enfadado dos ares do Catete, vaio presidir as reuniões semanais (...) que vale tanto aparato, se o conselho não se ocupa de um tratado de tal natureza. (...) mais esdrúxulo, ou antes, mais expressivo da displicência e da leviandade com que tratam essas coisas (...). Temos um Ministério da Agricultura e outro que se intitula do Trabalho, Indústria e Comércio. Seriam justo eles dois, o laboratório, a oficina onde se deveriam elaborar os planos dos tratados de comércio. (...) deles, não consta destes papéis uma palavra. ${ }^{282}$

Ao longo de sua fala, Octávio Mangabeira se identifica com a "minoria parlamentar". É digno de nota que nenhum dos industriais, mesmo os que não eram classistas, reivindica esta identidade. A "minoria" define-se, segundo ele, por seu programa, em termos de um dever de fiscalização e crítica ao governo.

\subsection{Paulo Martins e a Burocracia Estatal}

Paulo Dias Martins nasceu em Fortaleza, filho de um burocrata e político do Império. Formado em Direito, fez carreira como funcionário do Ministério da Fazenda, chegando a ocupar o cargo de Diretor das Rendas Internas, após elaborar uma reforma no Tesouro Nacional. Em 1934 elegeu-se representante dos funcionários públicos, tornandose deputado federal classista. Sua longa carreira burocrática - viria a aposentar-se no último posto da carreira fazendária - é trajetória semelhante às de outros membros do grupo que agora analisaremos.

A defesa de Tratado feita por Martins no plenário da Câmara consistiu em um longo artigo e sua argumentação é fundamentada em preceitos do liberalismo econômico e livre-cambismo, ainda que este não seja dogmático - bem de acordo com o "espírito do tempo", ele admite "certo protecionismo", porém limitado à proteção de indústrias

\footnotetext{
${ }^{281}$ Idem, p. 216.

${ }^{282}$ Idem, p. 221.
} 
"naturais" e produtivas, mas sempre insiste no fato de que este não poderia jamais prejudicar a exportação, atividade mais importante para o Brasil.

Mais relevante para os propósitos dessa análise é o fato de que apresenta uma concepção acerca do "caráter" da economia brasileira associada à ideia de "vocação agrícola" e uma posição quanto à forma de inserção do Brasil na economia mundial, baseada na noção de vantagens comparativas, extraída da economia política clássica ricardiana. ${ }^{283}$ Isto significa dizer que, para ele, o Brasil deveria manter e expandir sua inserção como produtor primário, dado que a produtividade agropecuária do Brasil seria incomparável à de qualquer indústria, exceto aquelas vinculadas diretamente ao setor primário (agroindústrias).

Passemos agora à análise mais detida de alguns dos elementos discursivos presentes na intervenção de Martins, bem como em algumas participações de outros membros desse grupo.

\subsubsection{A "vocação agrícola" e a legitimidade da Indústria nacional}

A visão de Martins sobre o "caráter" do Brasil deriva de suas concepções teóricas e ideológicas acerca da sua economia. Segundo ele, a economia de um país deveria se organizar de tal forma que se adequasse às suas "condições naturais". No caso brasileiro, isto resultaria em reconhecer o predomínio de uma "vocação agrícola". A enorme produtividade de suas terras, a vastidão de seu território e o clima favorável determinariam suas possibilidades concretas. Deriva daí a sua ideia de que almejar a transformação estrutural da economia, sob a direção do Estado e no sentido da industrialização, seria um projeto pouco desejável, ou até mesmo inviável. ${ }^{284}$

Apesar de reconhecer a existência de extenso parque industrial no Brasil, Martins sempre enfatiza sua importância subordinada para a economia. ${ }^{285}$ Além disso, ele sempre procura questionar a necessidade da presença no Brasil de certas indústrias. Empregando

\footnotetext{
${ }^{283}$ Tal teoria se baseia na ideia de que dois países podem extrair vantagens do comércio internacional, sempre que cada um se especialize na produção das mercadorias para as quais o custo relativo de produção no país seja menor, ou seja, aquela com maior produtividade. Consiste num dos fundamentos da teoria liberal do comércio. Cf. RICARDO, David. Princípios de economia política e tributação. Trad. Paulo Sandroni. São Paulo: Editora Nova Cultural, 1996.

${ }^{284}$ Anais, op. cit., v. XV (09/09/1935), p. 123.

${ }^{285}$ Idem, p. 151.
} 
um vocabulário característico de um antigo debate travado acerca da legitimidade da indústria nacional, Martins traz à tona a discussão acerca do caráter "artificial" 286 de algumas indústrias, tais como as de equipamentos, ${ }^{287}$ e dispara: "uma indústria artificial não pode merecer o nosso apoio". ${ }^{288}$

Seu colega, Renato Barbosa desenvolve o tema da artificialidade da indústria nacional, questionando a legitimidade da proteção dada às indústrias. Este tipo de política econômica seria, segundo ele, apenas uma forma de privilegiar "indústrias artificiais". As verdadeiras indústrias só poderiam se desenvolver junto com o desenvolvimento da agricultura e isto pressupunha um regime comercial livre:

A indústria está legitimada pela sua função econômica e social. A fonte originária da força de seu poder está longe de ser expressa por uma tarifa alta. Ela tem que haurir todos os seus recursos de que se alimenta da terra trabalhada e cultivada. É esse regime de favoritismo e privilégios que tem embaraçado o desenvolvimento da nossa agricultura e consequentemente comprometido o surto das nossas verdadeiras indústrias. Estas só poderão se mostrar estáveis, sólidas e prósperas quando se valem exclusivamente daquilo que produzimos. ${ }^{289}$

Seguindo a mesma linha de raciocínio, após uma breve análise das cláusulas do Tratado, Martins afirmou que não teriam sido afetadas "aquelas indústrias que alicerçam a economia nacional, porque manipulam abundantemente a nossa matéria-prima com o emprego de grandes capitais e oferecem emprego para numeroso operariado" ${ }^{290}$ Procura-se assim definir um critério para determinar qual é a "indústria que merece este nome", em suas próprias palavras. Finalmente, Martins critica os produtos da indústria nacional por sua qualidade supostamente inferior, o que seria um problema característico de toda "indústria artificial". 291

\footnotetext{
${ }^{286}$ Era considerada "indústria artificial" aquela cujas matérias primas e insumos só pudessem ser obtidos por meio de importações. LUZ, 1975, esclarece como esses foram os termos que opuseram os primeiros industrialistas brasileiros, como Amaro Cavalcanti, Serzedelo Correia e Jorge Street, e seus adversários agraristas.

${ }^{287}$ Idem, p. 149.

${ }^{288}$ Idem, p. 142.

${ }^{289}$ Anais, op. cit., v. XVI (11/09/1935), p. 262.

${ }^{290}$ Anais, op. cit., v. XV (09/09/1935), p. 152.

${ }^{291}$ Idem, p. 144.
} 


\subsubsection{Interesses Nacionais}

A definição sobre quais seriam os "interesses nacionais" é um dos pontos chave da argumentação deste grupo ligado à burocracia estatal. Segundo as ideias que expressaram no debate, tal definição deve ser um corolário da ideia de "vocação agrícola" do Brasil. Nesse sentido é que o "interesse geral do país", vinculado por sua natureza à agroexportação, é contraposto aos interesses supostamente particularistas da indústria nacional. O "problema da indústria" deveria, portanto, ser tratado apenas após a solução do "problema agrário", por definição o mais importante. ${ }^{292}$

Em polêmica com Simonsen, acerca do fechamento de uma fábrica de móveis metálicos, devido à assinatura do Tratado, Martins questionou: "Não acha V. Ex. mais importante sacrificar esses cem operários, essas centenas de contos de réis em favor dos interesses do país?". ${ }^{293}$ E rebatendo a argumentação de Galliez em favor da proteção à indústria, afirmou: "A tese de V. Ex. é contra o povo". ${ }^{294}$ Aqui transparece o emprego do léxico político, a fim de deslegitimar a posição da indústria. Assim, sendo oposta ao “povo”, por decorrência a posição dos industriais seria contrária à Nação.

E ainda em outra passagem, assevera:

Conseguiu ela [a indústria nacional], afinal, competir com a indústria estrangeira (...) concorrer naturalmente, sem artifícios, para o engrandecimento da Nação, ter em suma vida própria a ponto de dispensar o aniquilamento do país em seu proveito? Não. ${ }^{295}$

Fica claro como se constrói aí uma oposição entre os interesses (particulares) da indústria nacional, pouco competitiva, e que, portanto, dependia da proteção para sobreviver, e os interesses gerais, os quais eram ameaçados pelo excesso de proteção indevida. É a partir dessa ideia que Martins e seus correligionários tecem críticas ao protecionismo, defendido pelo grupo dos Industriais.

\footnotetext{
292 Idem, p. 124.

${ }^{293}$ Idem, p. 135.

${ }^{294}$ Idem, p. 142.

${ }^{295}$ Idem, p. 148.
} 


\subsubsection{Liberalismo clássico e crítica ao protecionismo}

Partindo da ideia liberal de que a política econômica deveria derivar das condições naturais de um país, Martins criticou as tentativas de intervenção do Estado na economia, tais como o protecionismo, como sendo medidas "artificiais", ineficazes e onerosas para a maioria do povo. ${ }^{296}$ Sua filiação ao liberalismo, de resto, pode ser facilmente atestada por suas próprias palavras: "Defendo (...) os princípios da economia clássica, os quais nunca falharam". ${ }^{297}$ Coerentemente, ele partiu para críticas às supostas tendências "autárquicas", associadas ao protecionismo:

(...) se cada país desejar produzir para si só e isolar-se da convivência universal, é claro que o comercio internacional pereceria e o mundo retrocederia às idades primevas. Esse isolamento econômico vem se acentuando cada vez mais pela imposição de pautas aduaneiras protecionistas. ${ }^{298}$

A ideia subjacente é a de que a política econômica deve se orientar por "leis naturais", que no caso seriam aquelas definidas pela economia liberal clássica. Este é um argumento que visa conferir autoridade científica exclusiva às suas posições. Fundamentando-se, assim, em tais "leis", Martins fez ainda mais um apelo em nome da liberalização do comércio e contra as doutrinas, tidas como "antinaturais", do protecionismo:

Queremos que as leis naturais voltem a ter seu império, afim de que desapareçam, para sempre os regimes de quotas, de contingenciamento, que restringem a produção e impedem o aumento das trocas, porque tudo está preso às doutrinas aloucadas (...). Deem liberdade ao comércio brasileiro, facilitem-lhe o crédito, abram-lhe as portas à importação e à exportação. ${ }^{299}$

Como um liberal convicto, Martins defendeu que a política econômica do Brasil deveria ser feita pela livre determinação dos mercados. Haveria espaço para o uso de tratados, mas desde que mantida a liberdade de movimentos e sem as peias da intervenção oficial, a qual ele identifica como "o grande mal”. Para ele, a situação de baixa nas exportações seria "consequência da malfadada economia dirigida que vai

\footnotetext{
${ }^{296}$ Idem, p. 121.

${ }^{297}$ Idem, p.121.

298 Idem, p. 123.

299 Idem, p. 165.
} 
devastando e empobrecendo o mundo". Arma a sua crítica, portanto, contra a intervenção governamental e o planejamento. ${ }^{300}$

A fim de atacar as ideias protecionistas, Martins afirma que sua adoção não resultaria em benefício da população em geral, sendo proveitosa apenas para algumas indústrias privilegiadas. Isto se deveria ao fato de que estas indústrias, na prática, se aproveitariam das tarifas elevadas para aumentar seus preços, promovendo assim a “crescente carestia da vida que atormenta o consumidor". Além disso, esse sistema não ofereceria proteção efetiva porque a elevação geral dos preços permitiria que os importados continuassem a entrar no país. ${ }^{301}$

Tal política ainda seria ineficaz no sentido da promoção do desenvolvimento da indústria nacional, garantindo apenas os lucros das indústrias já existentes, e em detrimento do conjunto dos consumidores e do restante da economia, que permaneceria atrasada. ${ }^{302}$ Contudo, apesar das acerbas críticas, ele admite certo protecionismo, definido vagamente como aquele que beneficia a coletividade. ${ }^{303}$ Para ele, as chamadas "indústrias-chave" careceriam de uma barreira protetora, mas ele não especifica exatamente quais seriam tais indústrias. ${ }^{304}$

\subsubsection{Visões sobre a crise}

Para Martins, bem como para Bias Fortes, o protecionismo ainda seria a causa central da crise econômica mundial, devido ao "egocentrismo das nações que, segregadas de outras, impedem a livre circulação das riquezas e a boa colocação da produção causas presumíveis do desequilíbrio do mundo". ${ }^{305}$ Ou seja, a fraca circulação, acarretada pelo fechamento protecionista, estaria gerando um quadro de subconsumo:

A crise é de consumo, de falta de colocação. (...) a possibilidade de novos mercados para entre eles colocar o excesso da produção é coisa possível. (...). E nada melhor para intensificar relações comerciais, colocar produtos e aumentar a exportação do que estabelecer acordos comerciais. ${ }^{306}$

\footnotetext{
${ }^{300}$ Idem, p. 165.

${ }^{301}$ Idem, p. 149.

302 Idem, p. 149.

${ }^{303}$ Idem, p. 165.

${ }^{304}$ Idem, p. 122.

${ }^{305}$ Idem, p. 123.

${ }^{306}$ Idem, p. 124.
} 
Partindo desse diagnóstico, um dos argumentos que este grupo utiliza para legitimar a ratificação do Tratado se encontra na proposição de que este seria uma das possíveis saídas para a superação da crise, ao promover a abertura de mercados externos para o Brasil. Também atribuem à crise causas relacionadas à desconfiança, à falta de crédito e uma realocação setorial momentânea do capital. É quase como se a crise nada mais fosse do que um "percalço" temporário a ser superado pela própria dinâmica do capital, o qual, devido ao fato de nunca se imobilizar, encontraria automaticamente uma saída. Cabia às nações apenas garantir o livre curso de suas tendências intrínsecas. ${ }^{307}$

\subsubsection{Uma questão prioritária: as receitas do Estado}

Parece-nos que um dos argumentos centrais, presente nos discursos de membros do grupo liderado por Paulo Martins para justificar a ratificação do Tratado no Congresso era a importância de se manter abertos os fluxos do comércio externo, visando à manutenção do equilíbrio das contas públicas. Trata-se de uma preocupação focada nas receitas do Estado. Martins, por exemplo, se preocupa em esclarecer que as reduções tarifárias concedidas aos produtos importados dos EUA não resultariam em uma redução na renda aduaneira. Pelo contrário, o Tratado proporcionaria maiores receitas, devido ao inevitável aumento dos volumes de comércio uma vez que estivesse em vigência. ${ }^{308}$

E o comércio seria o meio para se conseguir os recursos necessários para que o Brasil pudesse honrar os seus compromissos externos. Mais do que isso, seriam estes recursos também os meios necessários para a manutenção do aparelho do Estado. ${ }^{309} \mathrm{E}$ com isso, Martins reforça a ideia de que a manutenção de uma burocracia eficiente e independente era central para uma administração moralizada e adequada do Estado.

Mais de uma vez ele enfatiza esse aspecto da independência dos funcionários públicos: "Ninguém tem mais liberdade do que os funcionários públicos (...) me sinto no dever de defender minha classe. Temos absoluta independência". ${ }^{310}$ Assim procura construir a reputação de uma burocracia "autônoma", em relação à cúpula do Estado e às "classes produtoras", portanto, isenta em suas ações.

\footnotetext{
${ }^{307}$ Idem, p. 161.

${ }^{308}$ Idem, p. 152.

${ }^{309}$ Idem, p. 152.

${ }^{310}$ Idem, p. 128.
} 


\subsubsection{Projetos para o Brasil}

Os discursos de Paulo Martins, Renato Barbosa, Bias Fortes e de outros membros desse grupo, nos possibilitam delinear a concepção de um projeto nacional baseado na visão de um Brasil essencialmente agroexportador, mas com uma policultura diversificada, menos dependente de um único produto: "o Brasil, com os mais variados climas e zonas geologicamente diferentes, bem andaria se enveredasse pela policultura". ${ }^{311}$ Isto não significa, porém, que se desconsiderassem outras atividades econômicas. De fato, a indústria ocupa um lugar em suas concepções acerca da economia nacional, ainda que claramente secundário e subordinado.

Para este grupo, o setor externo era de longe o mais relevante na economia brasileira, sendo o "polo dinâmico de crescimento", tendo o comércio livre como seu mecanismo fundamental. Daí reforçarem a relevância dos tratados de liberalização comercial. $^{312}$ Também ressaltam a importância da proximidade com os EUA para que o Brasil se inserisse de maneira mais vantajosa nos mercados do mundo, afinal, a importância política crescente daquele país andava junto com a sua importância econômica. É nesse sentido, que, ao discorrer sobre as vantagens do Tratado de 1935, Martins ressalta, além dos ganhos em termos de saldos comerciais, a sua "conveniência por motivos de ordem política". 313

\subsection{Apontamentos gerais}

Ao analisarmos o discurso de Paulo Martins, é possível afirmar que este representante da elite burocrática brasileira mais não fez do que posicionar-se no debate de forma a se alinhar às posições oficiais do governo quanto ao Tratado, exatamente como o acusam seus detratores. Mas talvez o mais interessante seja a forma como o fez. A estrutura de seus argumentos busca sempre o recurso a um saber tido como "consensual" sobre a realidade econômica brasileira. Sua fala se reveste de autoridade científica e evoca muitos dados numéricos. Mas sempre o faz para reforçar a ideia de que

\footnotetext{
${ }^{311}$ Idem, p. 121.

312 Idem, p. 125.

${ }^{313}$ Idem, p. 164.
} 
o Brasil não deveria desviar-se de seus rumos históricos, de sua tradicional forma de inserção na economia mundial.

Devido à semelhança evidente das manifestações de outros representantes do grupo, assim como a força de seus próprios argumentos, tomamos Martins como representativo desse grupo para os fins dos apontamentos que faremos. Assim como outros participantes desse grupo, Martins expressa várias ideias compatíveis com o que Leme chama de "pensamento da Lavoura". ${ }^{314}$ Assim, se situa no campo de uma concepção sobre o mundo (e o Brasil) muito próxima à ideologia do consenso hegemônico, forjado em torno da supremacia das frações mercantis e agroexportadoras brasileiras. ${ }^{315}$ Mas não há nada, seja em sua conduta parlamentar, sua origem social ou em sua carreira que o ligue diretamente a estas frações de classe.

Nem sequer é correto dizer que o que visa - diretamente, ao menos - é defender o que podemos identificar como interesses dessas frações. Como veremos adiante, em meio a esta enxurrada de argumentos derivados da ideologia agrarista, Martins sustenta sua defesa do Tratado mais propriamente em considerações acerca do interesse de sua assinatura para a manutenção das rendas aduaneiras do Estado. Como os impostos do comércio internacional eram a principal fonte de receitas estatais, tratava-se de um elemento de interesse direto para a burocracia que dela dependia. Assim, ao invés de ser mero "representante dos interesses da agroexportação", nos parece que o grupo que defendia a ratificação do Tratado respondia também a demandas, interesses e projetos próprios.

Porém, tão importante quanto definir as motivações de sua posição, nos parece ser a simples constatação de que o arcabouço ideológico que a sustenta permanecia bastante eficaz. Isto pode ser afirmado, tendo-se em vista a recorrência desses argumentos no debate. De fato, à exceção do caso dos deputados industriais, princípios como o da predominância "vocacional" da agropecuária na economia brasileira, bem como da forma tradicional de inserção do Brasil na economia mundial parecem ter sido partilhados pela maioria - até mesmo pelos demais opositores do tratado.

\footnotetext{
${ }^{314}$ LEME, op. cit. Ver Introdução da presente dissertação.

315 ARRUDA, Pedro F. Liberalismo, direito e dominação da burguesia agrária na Primeira República brasileira (1889-1930). In: Revista ponto-e-vírgula, 1: 161-188, São Paulo, 2007.
} 
Assim, cabe apontar para o fato de que o consenso em torno da ideologia "da lavoura" era ainda em boa medida operacional, ainda que fosse cada vez mais questionado pelos intelectuais orgânicos ligados à fração industrial e até mesmo por intelectuais de corte tradicional, porém nacionalista e modernizador (e muitas vezes autoritário), como Azevedo Amaral. ${ }^{316}$ Tal questionamento se deu inclusive crescentemente no seio do Estado. ${ }^{317}$ Mas nos parece relevante ressaltar o quanto estes elementos de um novo consenso (um "projeto hegemônico"), em torno da industrialização, estavam ainda em disputa com outros, ainda dominantes. A construção da hegemonia deve, portanto, ser vista como um processo, com sua própria temporalidade, marcada por avanços, recuos, acordos e conflitos.

Isto nos permitiria inclusive matizar as interpretações que tendem a caracterizar como "industrialista" o Estado brasileiro pós-revolução de 1930. Ainda que seja bem certo que havia nele defensores ativos dessas concepções "modernizadoras" - e entre eles talvez possamos listar o próprio presidente Getúlio $\operatorname{Vargas}^{318}$-, também é fato que não se deve confundi-los com o próprio Estado. Afinal, no seio da burocracia que constitui o aparelho desse mesmo Estado, havia setores que esposavam outras concepções que ainda retinham clara vitalidade em meados da década de 1930.

\footnotetext{
${ }^{316}$ OLIVEIRA, Lúcia Lippi et al. (orgs.). Estado Novo: ideologia poder. Rio Janeiro: Zahar Ed., 1982.

${ }^{317}$ Cf. FONSECA, Pedro C. D. Instituições e política econômica: crise e crescimento do Brasil na década de 1930; CANO, Wilson. Crise de 1929, soberania na política econômica e industrialização In: BASTOS e FONSECA (orgs.), op. cit.

${ }^{318}$ FONSECA, Pedro Cezar Dutra. Vargas: o capitalismo em construção. São Paulo: Brasiliense, 1999.
} 


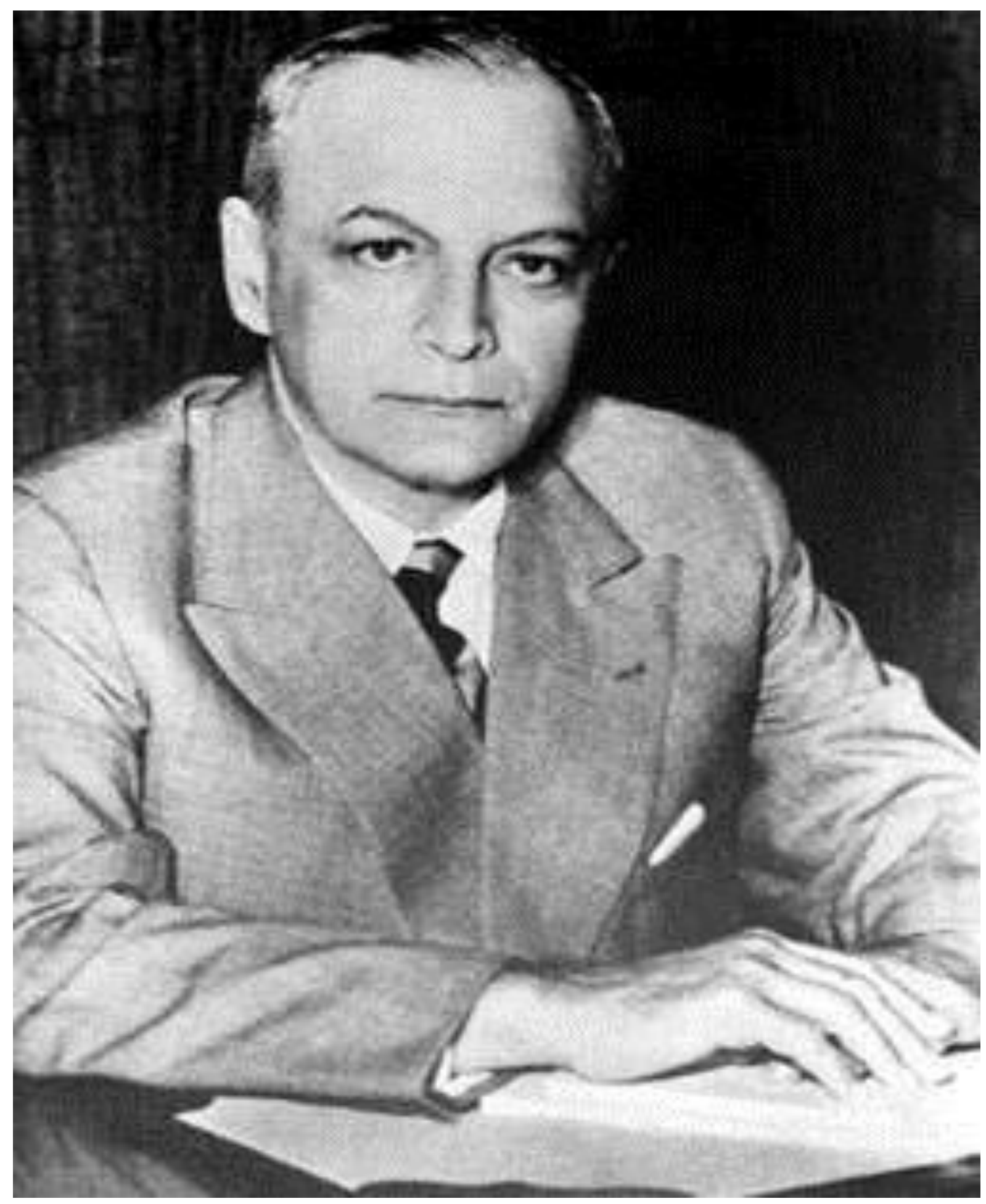

Figura 7.2. - Fotografia de Roberto Simonsen (c. 1937).

Fonte: Blog Arquitetura, URL: http://maquete-9d.blogspot.com.br/. (acessado em 20/05/2014) 


\section{Capítulo 8 - O Debate nas Associações de Classe e na Imprensa}

A fim de verificar a pertinência da interpretação, proposta nos capítulos anteriores, de que a defesa do Tratado ficou a cargo dos membros da elite política que ocupava posições na cúpula do Estado e de elementos de uma burocracia estatal em formação e que, portanto, não teria sido levada a cabo diretamente por representantes da "agroexportação" (como afirma a maior parte da literatura), cabe verificar a atuação das associações representativas das classes (ou frações) ligadas aos supostos interesses em contraposição.

Com este intuito, investigamos as atas de reuniões da Associação Comercial de São Paulo (ACSP) e da Sociedade Rural Brasileira (SRB), principal associação ligada à grande cafeicultura paulista - um dos interesses que, se supõe, seriam mais diretamente afetados pela ratificação do Tratado -, bem como as posições expostas oficialmente pela Federação das Indústrias do Estado de São Paulo (FIESP). Além disso, verificamos se e como os grupos se manifestaram em seus próprios periódicos associativos.

Finalmente, neste capítulo, analisamos a posição da grande mídia impressa, a partir da leitura de artigos publicados em alguns jornais de ampla circulação, naquele contexto, verificando as possíveis relações com as posições dos grupos já indicados.

\subsection{As associações de classe e o Tratado: o silêncio da Agricultura e a mobilização da}

\section{Indústria}

A Sociedade Rural Brasileira (SRB), associação representativa da classe rural, fundada no dia 19 de maio de 1919, na cidade de São Paulo, era o principal órgão associativo de classe da grande cafeicultura paulista, um dos grupos mais importantes para a economia agroexportadora do Brasil, bem como de outros produtores agrícolas, tais como os plantadores de algodão do estado de São Paulo e ambos eram grupos cujos interesses poderiam ser diretamente afetados pelo desenlace da ratificação do Tratado.

Contudo, a análise das atas das reuniões de conselho da SRB, relativas ao período de $1935-1936,{ }^{319}$ atesta que esta questão foi simplesmente ignorada por aquela entidade de classe. Não encontramos sequer uma menção ao Tratado, neste período crítico para os

\footnotetext{
${ }^{319}$ Atas das Reuniões da Diretoria, Sociedade Rural Brasileira, fev/1935 a jan/1936. Nota: algumas atas de reuniões foram extraídas de livros manuscritos, mantidos no arquivo histórico da SRB. Quando disponíveis, utilizamos as atas transcritas nos volumes da Revista da Sociedade Rural Brasileira, São Paulo: 1935-1936.
} 
debates sobre a sua ratificação. Vale notar que, de forma muito diversa dessa omissão quanto ao Tratado, outras questões relativas à política econômica nacional, que afetavam seus interesses de classe, tais como a "defesa do café", eram temas recorrentes de suas discussões. ${ }^{320}$

Por exemplo, o editorial da Revista da Sociedade Rural Brasileira critica a política de defesa do café tal como vinha sendo levada a cabo pelo Departamento Nacional do Café (DNC), pois seria esta baseada em uma doutrina abstrata e sustentando preços em demasiado elevados, estaria impedindo a colocação dos cafés de valor inferior e sustentando a superprodução do café. ${ }^{321}$ Novas críticas voltam a ser direcionada a atuação do DNC, em artigo de autoria do então presidente da SRB, Bento Sampaio Vidal, veiculado no jornal Folha da Manhã. ${ }^{322}$

Este fato, no mínimo curioso, se partirmos da interpretação corrente na historiografia acerca do Tratado, de que a defesa deste teria sido feita pelos representantes da agroexportação, a omissão por parte desta entidade representativa do segmento mais importante da cafeicultura nacional, o capital cafeeiro paulista, certamente coloca em questão essa interpretação, ao menos em sua versão mais simples e direta. Acreditamos, portanto, que seria necessário matizá-la. Se houve "representação" dos interesses da agroexportação no debate acerca do Tratado de 1935, esta não foi levada a cabo diretamente por representantes da produção agrícola no Estado de São Paulo.

Quanto a outras dimensões do pensamento dos líderes dessa classe, mostra-se interessante a análise do artigo, publicado no periódico da SRB, de autoria de seu presidente, Sampaio Vidal, o qual versa sobre o entendimento daquela associação acerca das origens da crise mundial. Neste artigo, a crise é atribuída ao "reajustamento pósPrimeira Guerra Mundial”, pois o excesso de capacidade produtiva instalada nos EUA durante a guerra teria gerado uma inflação monetária na economia norte-americana.

No caso brasileiro, a crise, denominada no referido artigo "a maior tempestade econômica que jamais se desencadeou sobre o mundo" chegou ao país através do abalo do mercado mundial do café e gerou uma evasão do ouro alocado na caixa de estabilização. Vidal ainda estende uma crítica à política de defesa do café do Governo Federal, afirmando que "o instituto de café andou mal em sustentar preço tão alto e não procurando dar saída ao estoque de café paulista”. Apregoa como solução uma disciplina

\footnotetext{
${ }^{320}$ Cf., por exemplo, Atas, op. cit., jan./1936.

321 "Estratégia cafeeira". In: Revista da Sociedade Rural Brasileira. Ano XV, no179, julho de 1935.

${ }^{322}$ Folha da Manhã, São Paulo, 29/06/1936.
} 
orçamentária e uma campanha de promoção da expansão e diversificação da produção, principalmente a do algodão. ${ }^{323}$

Em artigo de autoria de Mario Beni, na revista da SRB, há um exemplo da oposição de interesses percebida por aquela associação agrícola com relação à indústria. Segundo este artigo, "a política econômica do Brasil, já não resta dúvida, pende mais para as novas forças de produção [indústrias] que para as antigas (...) se analisarmos a legislação econômica nacional, (...) chegaremos à conclusão que, da complexa manifestação das vantagens e desvantagens aí descritas, a corrente mais sacrificada em benefício da sua concorrente é a da agricultura, da lavoura, do campo, enfim. E isso, então, torna-se tanto mais irônico quando se sabe que é ainda do campo que vivem o Brasil e os brasileiros". 324

Quanto à Federação das Indústrias do Estado de São Paulo (FIESP), foi notório o seu engajamento e mobilização, na figura de seus representantes classistas na Câmara, como Paulo Assumpção e Roberto Simonsen. Esta associação da classe industrial paulista, fundada em 1931, a partir do Centro das Indústrias do Estado de São Paulo (CIESP), congregava alguns dos principais líderes dos industriais, com destaque para o principal intelectual orgânico de sua fração de classe, Roberto Simonsen. Representava o núcleo dinâmico da industrialização nacional e, como visto no capítulo anterior, era também um centro de difusão do pensamento industrialista e de defesa da indústria nacional. A figura 8.8. mostra os índices acelerados de crescimento da indústria nacional - e, principalmente, da indústria paulista - no contexto da década de 1930, a partir do fenômeno da substituição de importações.

A indisponibilidade para consulta direta aos seus arquivos, no período em que realizamos a coleta de documentos para a presente dissertação, não nos permitiu uma análise mais extensa das fontes pertinentes para melhor caracterizar o teor do debate no interior desta associação da classe industrial paulista, uma das que mais se engajou no debate parlamentar contra a ratificação do tratado.

Contudo, há outras fontes que evidenciam sua atuação e posicionamento públicos. Por exemplo, a FIESP fez publicar, na Revista dos Tribunais, um artigo no qual expõe sua posição oficial, contrária ao Tratado. O posicionamento exposto segue, em linhas gerais, a argumentação de Roberto Simonsen em seu discurso, no plenário da câmara. O

\footnotetext{
${ }^{323}$ VIDAL, S. "A situação Atual”. in: Revista da Sociedade Rural Brasileira. Ano XVI, no188, São Paulo, abril de 1936.

324 BENI, M. "Economia nacional: problemas que escapam à meditação dos nossos homens públicos”. in: Revista da Sociedade Rural Brasileira. Ano XVI, no191, São Paulo, julho de 1936.
} 
ataque ao tratado se faz em nome da "ameaça aos interesses nacionais", representada pela redução tarifária indiscriminada sobre produtos manufaturados. O apelo é feito para que toda a Nação se sensibilize a esta causa comum. Não se pode verificar a autoria, de vez que o artigo é assinado pela entidade, mas devido ao teor dos argumentos e a forma da escrita, nos parece plausível a hipótese de que poderia ter saído da pena do próprio Simonsen. ${ }^{325}$

Há ainda uma circular da FIESP, datada de 30 de maio de 1935, a qual é citada nos debates da Câmara dos Deputados por vários dos participantes dos debates (inclusive pelo deputado Paulo Martins, que como vimos se alinhava ao campo dos defensores do Tratado). As inúmeras menções ao documento dão conta de que este teria servido como texto preparatório para os representantes da indústria no Congresso Nacional, a fim de municiá-los com argumentos e dados para embasar seu posicionamento. A referida circular trazia análises econômicas, entre as quais figura um quadro que procurava demonstrar como as mercadorias dos EUA, cujas taxas seriam as mais reduzidas pelo Tratado, em boa parte teriam similares de produção nacional, enquanto que aquelas de menor redução não possuiriam tais similares. Mais uma vez, não se pode auferir a exata autoria do documento. ${ }^{326}$

Finalmente, o já analisado discurso de Roberto Simonsen, no plenário da câmara, foi, segundo o próprio Simonsen, baseado em um artigo de sua lavra, que teria circulado nas reuniões da FIESP. Devido à notável influência das ideias de Simonsen no seio daquela associação e devido à semelhança dos argumentos com os dois documentos citados, parecem claras as linhas de força do posicionamento das associações de classe dos industriais. Tratava-se de uma critica ao livre-cambismo, pautada por reivindicações de proteção para a indústria nacional, representando seus interesses como sinônimos dos “interesses da Nação”. A exemplo da FIESP, o Centro Industrial do Brasil (CIB) também atuou por meio de seus representantes, tanto no Congresso Nacional, como no CFCE.

\footnotetext{
${ }^{325}$ FIESP, "O Tratado de Comércio com os Estados Unidos e a indústria Nacional". in: Revista dos Tribunais, São Paulo, 1935.

326 “Circular 6", 30/05/1930, FIESP-CIESP, Livro de Circulares (1929-1949), São Paulo, s.d.
} 


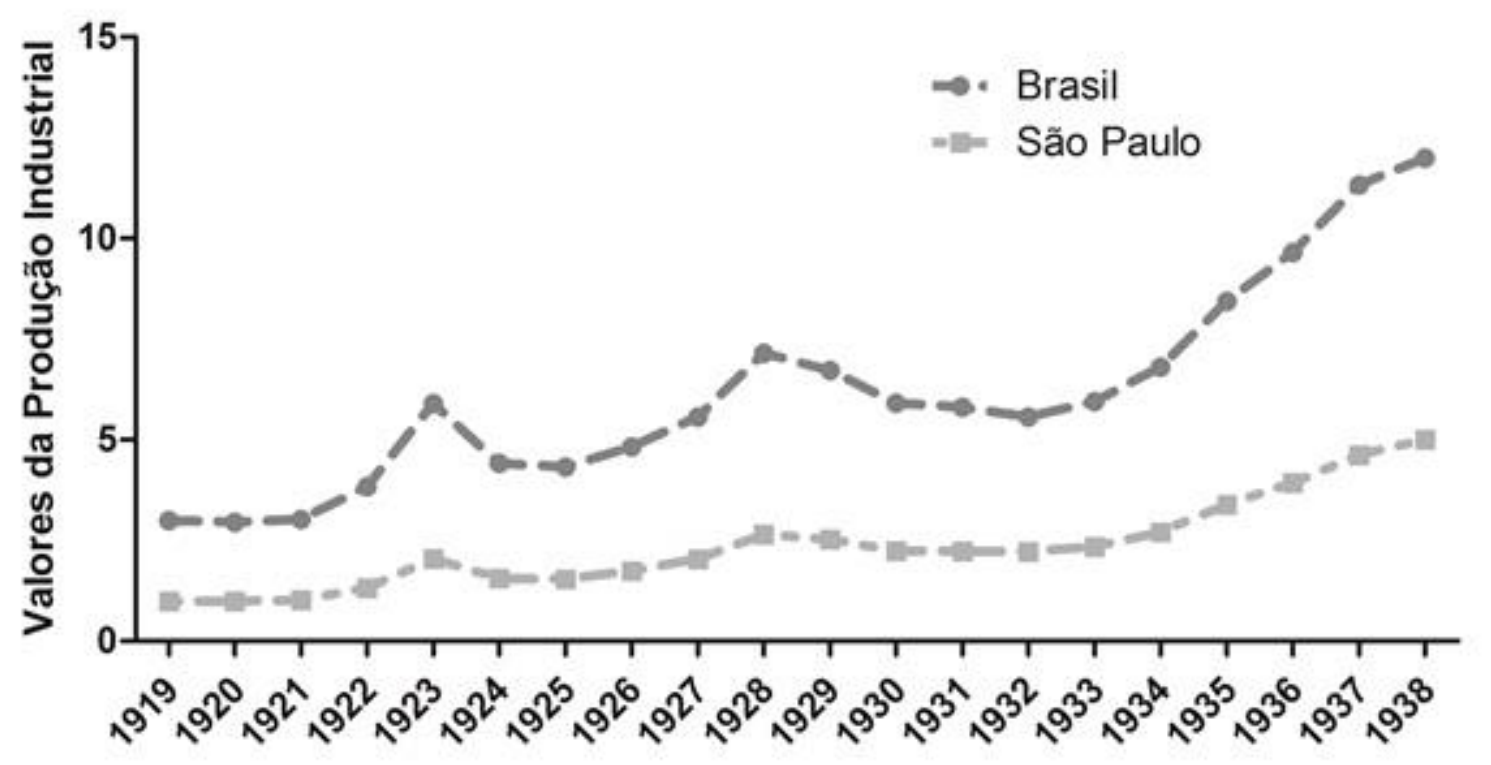

Figura 8.1. - Valores estimados totais da produção industrial - para o Brasil e para o estado de São Paulo (1919-1938).

Fonte: SIMONSEN, Roberto. Evolução Industrial do Brasil e outros estudos. São Paulo: Cia. Ed. Nacional, 1975.

Notas: * Valores em mil-réis de 1938.

8.2 A Associação Comercial de São Paulo e a representatividade da posição de Valentim Bouças

Se, de um lado, é claro o envolvimento, no debate extraparlamentar, de uma figura importante ligada ao comércio de exportação, Valentim Bouças, por outro, tanto os deputados classistas representantes do comércio, quanto as associações de classe ligadas ao comércio exportador - notadamente a Associação Comercial de São Paulo - pouco se envolveram no debate e quase nenhuma atenção a ele dedicaram, ${ }^{327}$ o que nos leva a crer que não se tratava, portanto, de uma representação de interesses mais amplos do comércio exportador, como esperamos será demonstrado mais à frente.

Em artigo publicado no Observador Econômico e Financeiro, órgão ligado às associações de classe do comércio, Valentim Bouças dirige seu ataque aos críticos da política comercial do Itamaraty. Defende ainda o plano comercial norte-americano "do Secretário [de Estado Cordell] Hull, de levar o mundo inteiro à adoção da cláusula de reciprocidade comercial, capaz de ativar o intercambio dos países hoje prisioneiros das

\footnotetext{
${ }^{327}$ Cf. Atas de reuniões da Associação Comercial de São Paulo (1935) e o único artigo acerca do Tratado que pode encontrado no periódico O Observador Econômico, n. 1, v.1, 1935.
} 
próprias muralhas alfandegárias". Defende também a "liquidação dos créditos congelados estrangeiros, principalmente os norte-americanos", que teria importância "sobretudo moral", e exalta a atuação de Osvaldo Aranha na embaixada. Rejeita por fím, veementemente, a "tese protecionista, que não se coaduna com as suas [do Brasil] necessidades fiscais, nem consulta os mais legítimos interesses de sua lavoura". ${ }^{228}$

Em outro artigo, também publicado no Observador Econômico e Financeiro, Valentim Bouças responde diretamente ao discurso proferido por Roberto Simonsen no plenário da Câmara dos Deputados, em 11/09/1935 - portanto, durante as sessões que discutiam a retificação do Tratado -, acerca da proposta de criação de um "Instituto Nacional de Exportação", consubstanciada em projeto de lei. Bouças se posiciona contrariamente à proposta de Simonsen. Neste longo artigo, ele rejeita "as teorias [econômicas]" nas quais se fundamentava a proposta.

Essencialmente, Bouças ecoa a condenação emitida oficialmente pela diretoria da SRB, em comunicado. Com argumentos de cunho liberal, quase "fisiocrático" ("jamais se poderá dizer que existe uma questão econômica num país sem inverno, de terra quase totalmente arável e fertilíssima"), ataca a ênfase de Simonsen no favorecimento ao mercado interno e desqualifica sua crítica à permanência estrutural da "monocultura" cafeeira no Brasil. Tudo isto se articula finalmente na defesa do Tratado de 1935, o qual, segundo Bouças, "veio a ser auspiciosamente ratificado" e na crítica à criação do referido Instituto de Exportação, o qual viria, segundo ele, a violar os termos do acordo com os EUA. $^{329}$

Contudo, questionamos aqui a representatividade da posição pessoal de Bouças, no que concerne ao posicionamento "de classe" do comércio exportador paulista. Bouças era o representante brasileiro da International Business Machines (IBM), grande corporação de máquinas e equipamentos, e devido a este vínculo com uma empresa norte-americana ele possuía interesse pessoal na manutenção de boas relações econômicas com os EUA. Contudo, a julgar pelas posições contidas nas atas de reunião a ACSP, sua posição não era representativa daquela do comércio Paulista como um todo. Outras manifestações dos diretores da ACSP, acerca do Tratado, questionam sua “pertinência para os interesses nacionais", sem, contudo, dar-lhe qualquer destaque. ${ }^{330}$

\footnotetext{
${ }^{328}$ BOUÇAS, V. "A política do Itamaraty”, in: Observador Econômico e Financeiro, Rio de Janeiro, n. 1, fev/1936, p. 24.

${ }^{329}$ BOUÇAS, V. “Aspectos da Política Econômica Brasileira”, Observador Econômico e Financeiro, Rio de Janeiro, n. 1, fev/1936, p. 49-67.

${ }^{330}$ Cf. Ata de reuniões da Associação Comercial de São Paulo, set/1935.
} 
Em ata de reunião da Associação Comercial do Estado de São Paulo (ACSP), em 1937, o seu presidente, Mário Azevedo, trouxe à pauta um relatório elaborado por aquela associação, a pedido do consulado dos EUA em São Paulo, acerca da "repercussão que na balança comercial vem tendo o Tratado de Comércio entre o Brasil e os Estados Unidos". Tal relatório teria sido elaborado a partir de uma consulta supostamente com "várias firmas (...) entre associados, industriais e importadores". Entre suas conclusões, destaca que:

Não se pode daí [do resultado auferido] afirmar, porém que tenha sido muito apreciável o aumento de importação de mercadorias de procedência americana, em vista de terem sido as vantagens do tratado estendidas aos demais países que com o Brasil mantem tratados de nação mais favorecida. Por outro lado, não existem dados que possam elucidar sobre os efeitos do tratado na atividade industrial, mas acredita-se que as indústrias locais não se tenham ressentido, de vez que das mercadorias favorecidas, poucas tem similares de fabricação nacional (...) [também] o tratado não teve não teve grande influência na exportação de produtos nacionais para os Estados Unidos. (...) Com relação às importações procedentes dos EUA, se é verdade que acusam aumento em relação a certas mercadorias é certo que o foi com desvantagem para o nosso país que não teve a desejada compensação na balança comercial. ${ }^{331}$

O documento acima demonstra claramente a percepção do pequeno impacto concreto do Tratado na economia nacional, tanto do comércio de importação e exportação, quanto na produção agrícola ou industrial, apesar de reconhecer a falta de uma mensuração adequada para auferir tais efeitos. Além disso, mostra como a ACSP não se inclinou favoravelmente ao Tratado, percebendo-o como, na melhor das hipóteses inócuo e, na pior delas, prejudicial à economia nacional.

\subsection{O Tratado na imprensa}

Os grupos de interesse, conformados em torno da questão da ratificação do tratado, procuraram sensibilizar a opinião pública por intermédio de campanhas de ampla repercussão na imprensa. A maior parte dos jornais se colocou contra o tratado ou, pelo menos, contra a forma pelo qual ele foi negociado, isto é, sem consulta aos grupos interessados.

O Jornal, órgão de propriedade do empresário Assis Chateaubriand, por exemplo, afirmava que vários produtos nacionais seriam prejudicados, tais como o algodão (devido

${ }^{331}$ Ata da 28a Reunião Ordinária do exercício de 1937, ACSP, São Paulo, 30/09/1937. 
às reduções de tarifas para roupas de algodão americanas) e o açúcar (devido às reduções de tarifas para doces). ${ }^{332}$

O Jornal liderou a crítica da impressa ao tratado, com uma série de artigos assinados por "Um Observador Industrial”, o qual questionava a justeza do acordo, "a proteção intransigente dos EUA à sua própria produção" e "a ameaça à industrialização brasileira" transformando o Brasil "num satélite dos EUA (...), afetando cerca de 600 fábricas e 8 mil trabalhadores". 333

Um artigo em outro jornal, o carioca A Pátria, alertou quanto aos "danos causados à produção e ao emprego nacionais" pelo Tratado, principalmente em São Paulo, onde, em decorrência de sua entrada em vigor, seriam fechadas cerca e 300 fábricas, o que resultaria, segundo o artigo, na perda de mais de 5.000 empregos. ${ }^{334}$

A linha argumentativa desses artigos procurava ressaltar a "ameaça aos interesses nacionais" que o Tratado representaria se ratificado. Presa ainda fundamentalmente a concepções liberais, os argumentos, contudo, enaltecem a indústria nacional e o seu papel para a renda do país. A condenação maior, porém, recai sobre o "autoritarismo" do governo federal e, principalmente, de Vargas, uma vez que haviam conduzido as negociações do Tratado em segredo e "sem consulta às classes produtoras".

Do outro lado, Valentim Bouças, de forma coerente com sua atuação junto ao governo e à ACSP, empreendeu campanha pessoal na imprensa, a fim de mobilizar forças a favor do tratado, escrevendo sob o pseudônimo "Um Observador Brasileiro", no jornal paulista Correio da Manhã. Segundo ele, as únicas indústrias que sofreriam com a concorrência estadunidense eram "manufaturas parasíticas enquistadas em nosso sistema econômico, dependentes de barreiras protecionistas". 335

Em carta de junho de 1935, endereçada a Osvaldo Aranha, Bouças deixou clara sua disposição de iniciar uma campanha na imprensa contra os "jornais que, pagos pelos 'Senhores de Indústria' se espalhavam por todo o Brasil atacando a sua pessoa [Osvaldo Aranha] e o tratado americano". Anuncia ainda a intenção de imprimir 5 mil panfletos para "atingir os congressistas e todos aqueles que podem influir na opinião pública". 336

Apesar dessas manifestações de Valentim Bouças, fica patente a tendência desfavorável ao Tratado, exibida pela maior parte dos artigos da imprensa analisados.

\footnotetext{
332 O Jornal, Rio de Janeiro, 06/03/1035.

333 O Jornal, 08/06/1935.

${ }^{334}$ A Pátria, Rio de Janeiro, 08/06/1935.

${ }^{335}$ Correio da Manhã, São Paulo, 25/06/1935.

${ }^{336}$ Carta de Bouças a OA, Rio de Janeiro, 28/06/1935, Arquivo AO.
} 
Segundo D’Araújo e Moura, ${ }^{337}$ a ação da FIESP e outras associações ligadas à classe industrial, tais como o CIB, inclusive através da encomenda direta de artigos a estas publicações, teriam sido os motivadores desse alinhamento. Contudo, não pudemos verificar documentalmente tal fato, visto que não foi possível localizar referências documentais que atestem que tais artigos tivessem sido "encomendados" por tais entidades.

${ }^{337}$ D'ARAÚJO e MOURA, op. cit., p. 60. 


\section{CONCLUSÃO}

A partir dos argumentos apresentados no presente trabalho, verificamos que nos documentos relativos ao debate sobre a ratificação do Tratado de Comércio Brasil-EUA, havia elementos que podem nos servir para problematizar ou qualificar algumas das interpretações presentes na historiografia. Entre elas, figura em destaque a visão sobre a conformação de grupos de interesse em torno do projeto de ratificação parlamentar do Tratado.

O mapeamento dos grupos que se enfrentaram no debate, observado na historiografia, em geral se apresenta nos seguintes moldes: aponta-se para um quadro político configurado, de um lado, pela representação classista industrial junto à "oposição" ao governo e, do outro, à "situação". Contudo, este último grupo é vagamente definido e diretamente associado aos "interesses das elites agrárias" ou "elites tradicionais", ainda que isto seja feito sem grande respaldo na documentação disponível.

É interessante então notar que, nos documentos analisados na presente dissertação, nenhuma das manifestações em defesa do Tratado foi encaminhada por qualquer um dos deputados da bancada classista representante da "lavoura e pecuária". Apenas um representante do "comércio" participou, porém, timidamente. De fato, os principais defensores foram essencialmente os deputados classistas representantes do funcionalismo público e outros burocratas de carreira, tais como Paulo Martins e Diniz Júnior. Ao considerarmos suas trajetórias biográficas, não encontramos evidências de uma relação direta destes com as ditas "elites agrárias".

Este simples fato já nos parece em si suficiente para que seja necessário qualificar as afirmações da literatura quanto aos grupos constituintes do debate. Ao invés da tradicionalmente proposta oposição indústria versus agroexportação, talvez seja mais correta a alternativa indústria versus burocracia estatal.

Foi possível identificar, durante a análise dos discursos dos defensores do Tratado, a presença de visões sobre a natureza da economia e da sociedade brasileiras e concepções de política econômica, as quais podem ser associadas ao pensamento que fora 
predominante neste período de clara hegemonia das elites agroexportadoras. ${ }^{338}$ São exemplos dessas visões, uma política comercial fundamentada no liberalismo econômico, de viés clássico, a defesa do caráter essencialmente agrário do Brasil e o postulado da complementaridade entre a economia brasileira e a dos centros industriais.

Tais concepções eram então ainda muito fortes - talvez predominantes - no seio da elite política e da burocracia estatal, contribuindo para configurar uma formação ideológica particular de uma parcela dos agentes do Estado, ${ }^{339}$ a qual não poderíamos caracterizar como "industrialista". Não seria também pura e simplesmente "liberal", tendo em vista os aportes de ideias positivistas e outras de origens diversas. Além disso, tendo em vista a natureza das fontes das receitas fiscais do Estado, o incentivo às exportações - e o café era de longe o principal produto da pauta brasileira - era sem dúvida de grande interesse para a sustentação política da burocracia estatal. ${ }^{340}$

Assim, sugerimos uma hipótese interpretativa alternativa para o episódio estudado: os principais defensores do Tratado faziam parte de uma elite política ou da burocracia estatal, ambas formadas e educadas em um período de forte hegemonia do pensamento liberal. Empenharam-se nessa defesa, em nome de uma ideologia particular afinada em vários aspectos com os interesses das elites agrárias -, ainda que não necessariamente motivados pela defesa direta de tais interesses.

Nesse sentido é que procuramos compreender a inação de representantes diretamente ligados às frações das classes proprietárias, cujos interesses seriam supostamente os mais afetados (positivamente) pela ratificação parlamentar do Tratado. E também a atuação dos membros da burocracia estatal, em defesa daquele acordo comercial. A hipótese que sugerimos é a de que as frações ligadas à produção agrícola - e em especial o grupo dos cafeicultores - ainda gozavam de posição hegemônica, mesmo que esta já não fosse inconteste. Além disso, muitas das ideias dominantes ainda eram as suas. Portanto, a defesa de certos interesses objetivos destes grupos, por parte de membros da elite política ou da burocracia que ocupavam postos-chave na estrutura do

\footnotetext{
${ }^{338}$ ARRUDA, Pedro Fassoni. Liberalismo, direito e dominação da burguesia agrária na Primeira República brasileira (1889-1930). in: Revista ponto-e-vírgula, 1: 161-188, São Paulo, 2007.

339 Idem, ibdem.

340 “(...) os estados tinham a disposição os imensos recursos gerados pelos impostos gerados pela exportação de mercadorias. Uma parte considerável deste valor, contudo, escoava diretamente para os cofres do Governo Federal já que este se apropriava dos impostos sobre as importações [tornadas possíveis pelas divisas obtidas com as exportações]". Cf. ARRUDA, 2012, op. cit., p. 261.
} 
Estado, por vezes acabava sendo feita sem que fosse necessária a participação direta de elementos oriundos de suas fileiras ou de suas instituições representativas.

Quanto aos Industriais, estes se organizaram sob a liderança de alguns de seus intelectuais orgânicos - notadamente Roberto Simonsen - e partiram em ação coesa contra a ratificação do Tratado, representando-o como "nocivo aos interesses nacionais". Na argumentação destes líderes industriais durante o debate estudado, foi possível identificar uma preocupação com a defesa da posição da indústria frente aos ataques de seus opositores, uma vez que estes consideravam a indústria nacional "parasitária", ou "artificial", pouco contribuindo para o engrandecimento nacional.

É certo que não se deve exagerar na proposição de que havia grande oposição de interesses entre as diversas frações da burguesia brasileira, uma vez que conflitos entre elas eram quase sempre limitados e resolvidos pela via da conciliação. Todavia, em certos momentos, essas disputas pela liderança do bloco no poder e, portanto, também pela direção do Estado, tornaram-se elementos constitutivos da política nacional, dando caráter às cisões e conflitos no seio das frações das classes dominantes e elites políticas brasileiras.

Nos chama a atenção o número de vezes em que a expressão "interesse nacional” é empregada ao longo deste debate, a fim de legitimar uma ou outra posição. Nossa interpretação é a de que se tratava de um período no qual a hegemonia do pensamento ligado às frações agrárias ainda podia ser sentida, mas se encontrava em crise. Seus projetos nacionais eram crescentemente questionados, abrindo espaço para novos projetos, como parte de uma disputa pela construção de uma nova hegemonia.

A crise deste consenso construído fundamentalmente a partir das ideias, concepções e valores associados às frações agrárias, contudo, não significa necessariamente que estes tivessem sido suplantados, de forma rápida, definitiva, ou inequívoca, por outro consenso hegemônico de caráter industrialista. A hegemonia de uma classe ou fração e a conquista da supremacia política, tal como propõe Gramsci, é construída historicamente, ${ }^{341}$ podendo ser melhor compreendida, portanto, como um processo e não como mero evento, ou "momento" de clara ruptura.

\footnotetext{
${ }^{341}$ Ver nossa discussão no Capítulo 1.
} 


\section{BIBLIOGRAFIA}

ABREU, Alzira Alves et. al. (coord.). Dicionário Histórico-Biográfico Brasileiro. $2^{a}$ ed. Rio de Janeiro: FGV, 2001. Disponível on-line. URL: http://cpdoc.fgv.br/acervo/dhbb. Acessado em 21/12/2011.

ABREU, Marcelo de Paiva. O Brasil e a Economia Mundial, 1930-1945: políticas econômicas externas e relações econômicas internacionais. Rio de Janeiro: Civilização Brasileira, 1999.

(org.). A ordem do progresso: cem anos de política econômica republicana (1889-1989). Rio de Janeiro: Campus, 1989.

La Argentina y Brasil en los años treinta: efectos de la política económica internacional británica y estadounidense. In: Desarrollo Económico, v. 24 , n. 96 , jan-mar, 1985 , p. 543-559.

ALBULQUERQUE, José; SEITENFUS, Ricardo; Castro Sergio. (orgs) Sessenta anos de política externa brasileira (1930-1990). Rio de Janeiro: Editora Lúmen Júris, 2006.

ALVERGA, Carlos F. R. P. de. Teoria marxista do estado capitalista: uma comparação entre Gramsci e Poulantzas. In: Jus Navigandi, abr/2011. URL: http://jus.com.br/revista/texto/18964/teoria-marxista-do-estado-capitalista-umacomparacao-entre-gramsci-e-poulantzas, acessado em 16/08/2012.

AQUILES, Affonso C. O conceito de classe em Ricardo Antunes e Edward Thompson: algumas aproximações. In: Acta Scientiarum. Human and Social Sciences. Maringá, v. 33 , n. 1, p. 13-19, 2011

ARÓSTEGUI, Julio. A pesquisa histórica: teoria e método. Bauru: EDUSC, 2006.

ARRIGHI, Giovanni. O Longo Século XX. São Paulo: Editora UNESP, 1996.

ARRUDA, Pedro F. Liberalismo, direito e dominação da burguesia agrária na Primeira República brasileira (1889-1930). In: Revista ponto-e-vírgula, 1: 161-188, São Paulo, 2007.

Capitalismo Dependente e Relações de Poder no Brasil: 1889-1930.

São Paulo: Expressão Popular, 2012.

BANDEIRA, Luiz Alberto Moniz. Presença dos Estados Unidos no Brasil. Rio de Janeiro: Civilização Brasileira, 2007.

BASTOS, Pedro P. Z. e FONSECA, P. C. D. (orgs.) A Era Vargas: desenvolvimentismo, economia e sociedade. São Paulo: EDUNESP, 2012. 
BARBOSA, Wilson do N. O problema da metodologia na prática da pesquisa social. Palestra em 30.04.1992. Programa de Pós-Graduação. Departamento de História. FFLCH-USP.

- Acerca da Superestrutura. Palestra proferida no Departamento de História da Faculdade de Filosofia, Letras e Ciências Humanas da USP. 03.08.1989.

BARRETO, Fernando P. de Mello. Os sucessores do Barão: relações exteriores do Brasil, 1912-1964. São Paulo: Paz e Terra, 2001.

BARROS, José D’Assunção. Teoria da História. vol. 1: Princípios e conceitos fundamentais. Petrópolis: Vozes, 2011 Os Campos da História - uma introdução às especialidades da História. In: Revista HISTEDBR On-line. Campinas, n.16, p. 17 -35, dez. 2004.

BEIRED, José Luis Bendicho. Sob o signo da nova ordem: intelectuais autoritários no Brasil e na Argentina (1914-1945). São Paulo: Edições Loyola, 1999.

BIANCHI, Álvaro. Empresários e ação coletiva: notas para um enfoque relacional do associativismo. In: Revista Sociologia Política. Curitiba, 28, jun/2007a.

Estratégia do contratempo: notas para uma pesquisa sobre o conceito gramsciano de hegemonia. In: Cadernos CEMARX. Campinas, nº 4, $2007 \mathrm{~b}$.

BIELSCHOWSKY, Ricardo. Pensamento econômico brasileiro: 1930-1964 O ciclo ideológico do desenvolvimentismo. Rio de Janeiro: Contraponto, 2001.

BORGES, Vavy P. “Anos trinta e política: conceitos, imagens e temas". In.: LusoBrazilian Review, XXXVI II (1999) pp. 109-126.

BOTTOMORE, Tom. (ed.) Dicionário do pensamento marxista. Rio de Janeiro: Jorge Zahar ed., 2001.

BRANDÃO, Gildo Marçal. Linhagens do pensamento político brasileiro. São Paulo: Aderaldo \& Rotschild Ed., 2007.

BRANDÃO, Nágela A. e DIAS, Edmundo F. A questão da ideologia em Antonio Gramsci. In: Trabalho \& Educação, vol.16, n 2, 2007.

BRAUDEL, Fernand. Civilização Material, Economia e Capitalismo: séculos XV-XVIII. São Paulo: Martins Fontes, 1996.

CAMARGO, Aspásia; DE ARAÚJO, João Hermes Pereira; SIMONSEN, Mário Henrique (orgs). Osvaldo Aranha: a estrela da revolução. São Paulo: Mandarim, 1996.

CAPELATO, Maria Helena. Os Arautos do Liberalismo: imprensa paulista (1920-1945). São Paulo: Brasiliense. 1989. 
CARDOSO, Ciro Flamarion S. História e paradigmas rivais. In: VAINFAS, Ronaldo e CARDOSO, Ciro F. S. (orgs).Domínios da história. SP: Campus, 2011.

. CARDOSO, C. F. (org.) Domínios da História - Ensaios de Teoria e Metodologia. São Paulo: Editora Campus, 1997.

e Héctor P B.. Os métodos da História. $6^{\mathrm{a}}$ Ed. Rio de Janeiro: Edições Graal, 2002.

CARDOSO Fernando H. Empresário industrial e desenvolvimento econômico no Brasil. São Paulo, Difusão Européia do Livro: 1972.

CARONE, Edgard. Pensamento industrial no Brasil. São Paulo: Difel, 1977. A República Nova (1930 - 1937). São Paulo: Difel, 1974.

CARNOY, Martin. Estado e teoria política. 16ª ed. Campinas: Papirus, 2011.

CEPÊDA, Vera. Limites e impasses: Roberto Simonsen e a formação da ideologia industrialista no Brasil. São Paulo: FFLCH/USP, 2003 - Tese de Doutorado.

CERVO, Amado e BUENO, Clodoaldo. História da Política Exterior do Brasil. Brasília: EdUnB, 2002.

CHARTIER, Roger. A História Cultural entre práticas e representações. Rio de Janeiro: Bertrand Brasil, 1990.

CHAUI, Marilena. O que é Ideologia. São Paulo: Brasiliense, 1981.

CODATO, Adriano N. Elites e instituições no Brasil: uma análise contextual do Estado Novo. Tese de Doutorado apresentada ao Programa de Pós-Graduação em Ciência Política do Instituto de Filosofia e Ciências Humanas da Universidade Estadual de Campinas, Campinas, 2008.

e PERISSINOTTO, Renato M. O Estado como instituição. Uma leitura das 'obras históricas' de Marx. In: Crítica Marxista n. 13, out. 2001.

Elitismo versus marxismo? Por uma agenda empírica de pesquisa. In: Anais do 32 Encontro Anual da ANPOCS, 2008.

CORSI, Francisco Luiz. Estado Novo: política externa e projeto nacional. São Paulo: UNESP, 2003.

Brasil e Argentina: uma análise das políticas econômicas do período 1930-1945. In: Revista de Economia Política e História Econômica, número 05, julho de 2006. p. 46-47. 
COUTINHO, Carlos Nelson. Gramsci: um estudo sobre seu pensamento político. Rio de Janeiro: Civilização Brasileira, 2007.

2011.

. O leitor de Gramsci. Rio de Janeiro: Civilização Brasileira,

D’ARAÚJO, Maria Celina Soares. O Estado Novo. Rio de Janeiro: Jorge Zahar, 2000.

(org.) As instituições brasileiras da Era Vargas. Rio de

Janeiro: Ed. UERJ: Ed. Fundação Getulio Vargas, 1999.

DEAN, Warren. A industrialização de São Paulo, 1880-1945. 3a ed., São Paulo: Difel, 1971.

DINIZ, Eli. Empresário, Estado e Capitalismo No Brasil: 1930/1945. Rio de Janeiro, Paz e Terra, 1978.

O Estado Novo: estrutura de poder e relações de classe. In FAUSTO, Boris (ed.). História geral da civilização brasileira. O Brasil Republicano. $3^{a}$ ed., São Paulo: Difel, 1986, tomo III, vol. 3.

DRAIBE, Sônia. Rumos e Metamorfoses: um estudo sobre a constituição do Estado e as alternativas da industrialização no Brasil. Rio de Janeiro: Paz e Terra, 2004.

EAGLETON, Terry. Ideologia: uma introdução. São Paulo: Boitempo, 1997.

FAUSTO, Boris (ed.). História geral da civilização brasileira. O Brasil Republicano. $3^{\text {a }}$ ed., São Paulo: Difel, 1986, tomo III, vol. 3.

Companhia das Letras, 1997.

Jorge Zahar, 2001.

O pensamento nacionalista autoritário (1920-1940). Rio de Janeiro:

FERREIRA, Jorge; DELGADO, Lucília de Almeida Neves (orgs.). O tempo do nacionalestatismo: do inicio da década de 1930 ao apogeu do Estado Novo. $2^{\mathrm{a}}$ Ed. Rio de Janeiro: Civilização Brasileira, 2007.

FONSECA, Pedro Cezar Dutra. Vargas: o capitalismo em construção. São Paulo: Brasiliense, 1999.

Sobre a intencionalidade da política econômica industrializante do Brasil na década de 1930. In: Revista de Economia Política. 23 (1), janeiro/março 2003, p. 141.

FONT, Mauricio A. "Cofee planters, politics and development in Brazil" in: Latin American Research Review. Vol. 22, n. 3 (1987) pp. 69-90.

FURTADO, Celso. Formação econômica do Brasil. 20a Ed. São Paulo: Ed. Nacional, 1985. 
GAMBINI, Roberto. O duplo jogo de Getúlio Vargas: influência americana e alemã no Estado Novo. São Paulo: Ed. Símbolo, 1977.

GRAMSCI, Antonio. Cadernos do cárcere. Tradução e edição de Carlos Nelson Coutinho. Rio de Janeiro: Civilização Brasileira, 2003.

GRESPAN, Jorge. Considerações sobre o método. In: PINSKY, C. B. e DE LUCA, T. R. (orgs.) O Historiador e suas fontes. São Paulo: Contexto, 2009.

FARIAS, Francisco P. de. Frações burguesas e bloco no poder: uma reflexão a partir do trabalho de Nicos Poulantzas. In: Crítica Marxista, n. 28, 2009.

HILTON, Stanley E. O Brasil e as grandes potências: aspectos políticos da rivalidade comercial. Trad. Carlos Nelson Coutinho. Rio de Janeiro: Civilização Brasileira, 1977.

Vargas and Brazilian economic development, 1930-1945: A reappraisal of his attitude toward industrialization and planning. Journal of Economic History. 35, Dez 1975.

HUNT, E. K. História do pensamento econômico. Trad. José Ricardo Brandão Azevedo e Maria José Cyhlar Monteiro. Rio de Janeiro: Elsevier, 2005.

JESSOP, Bob. Putting the capitalist state in its place. Oxford: Blackwell Publishing, 1990.

LAMOUNIER, Bolivar. "Formação de um pensamento político autoritário na primeira república: uma introdução". In: FAUSTO, B. (org.) Historia Geral da Civilização Brasileira. T. III, v. 2. Rio de Janeiro: Bertrand Brasil, 1997. pp. 343-374.

LAUERHASS, Júnior Ludwig. Getúlio Vargas e o triunfo do nacionalismo brasileiro. São Pualo: Editora da Universidade de São Paulo, 1986.

LEFORT, Claude. O que é burocracia? In CARDOSO, F. H. e MARTINS, C. E. (Orgs.) Política \& Sociedade. São Paulo: Nacional, 1979.

LEOPOLDI, M. A. P. Política e Interesses na Industrialização Brasileira. As associações dos industriais, a política econômica e o Estado. 1. ed. São Paulo: Paz e Terra, 2000.

LEME, Mariza Saenz. O Pensamento Industrial no Brasil. Tese de Mestrado apresentada ao Departamento de História da FFLCH-USP, em 1976.

LIMA, Heitor Ferreira. História do Pensamento Econômico no Brasil. São Paulo: Cia. Editora Nacional, 1976.

LIMONCIC, Flavio; MARTINHO, Francisco Carlos Palomares (orgs.). Intelectuais do Antiliberalismo: projetos e políticas para outras modernidades. Rio de Janeiro: Civilização Brasileira, 2010. 
LUZ, Nícia Villela. A luta pela industrialização do Brasil, 1808 a 1930. $2^{\text {a }}$ Ed. São Paulo: Alfa-Omga, 1975.

MANCUSO, Wagner P. "O Empresariado como ator político no Brasil: Balanço da Literatura e agenda de pesquisa". In.: Revista Sociologia Política. Curitiba: 28, jan/2007.

MARX, Karl. Manifesto do Partido Comunista. Lisboa: Editorial Avante, 1997.

. O 18 de Brumário de Luís Bonaparte. Trad. Nélio Schneider. São Paulo: Boitempo, 2011.

Critica da filosofia do direito de Hegel. São Paulo, 1977.

e ENGELS, Friedrich. A ideologia alemã. São Paulo: Boitempo, 2007.

MARTUSCELLI, Danilo Enrico. Elite e classe dominante: notas sobre o marxismo inspirado na teoria das elites. In: Marxismo: teoria, história e política. São Paulo: Alameda, 2011.

MAZA, Fábio. O idealismo prático de Roberto Simonsen: ciência, tecnologia e indústria na construção da nação. São Paulo: Instituto Roberto Simonsen, 2004.

MELLO, João M. Cardoso de. O capitalismo tardio. 11 ${ }^{\text {a }}$ Ed. Campinas: Facamp, 2009.

MOTTA, Rodrigo P. S. Em guarda contra o "perigo vermelho": O anticomunismo no Brasil (1917-1964). São Paulo: Perspectiva, 2002.

MOURA, Gerson. Autonomia na dependência: A política externa Brasileira de 19351942. Rio de Janeiro: Nova Fronteira, 1980.

NASCIMENTO, Benedicto Heloiz. A ordem Nacionalista Brasileira: o nacionalismo como política de desenvolvimento durante o Governo Vargas (1930-1945). São Paulo: Humanitas, 2002.

NOVAIS, Fernando A. e FORASTIERI, Rogério (org.). Nova História em perspectiva. V. 1. São Paulo: Cosac Naify, 2011.

OLIVEIRA, Lúcia Lippi. A questão nacional na Primeira República. São Paulo: Brasiliense, 1990.

; VELLOSO, Mônica Pimenta; GOMES, Ângela Maria de Castro. Estado Novo: ideologia poder. Rio Janeiro: Zahar Ed., 1982.

PANDOLFI, Dulce (org.). Repensando o Estado Novo. São Paulo: FGV, 1999.

POULANTZAS, Nicos. O Estado, o poder, o socialismo. Rio de Janeiro/RJ: Graal, 1985. Poder político e classes sociais. São Paulo, ed. Martins Fontes,

1977.

PRADO Jr. Caio. História Econômica do Brasil. São Paulo: Brasiliense, 1977. 
PRADO, Maria L. C. Uma introdução ao conceito de identidade. In. Cadernos de Seminário Cultura e Política nas Américas, vol. 1, 2009, p. 66-71.

REIS, José Carlos. "Marxismos e Annales: 'programas históricos' complementares antagônicos ou diferenciados." in: Varia Historia, Belo Horizonte, n 19, Nov./98, p.6891.

RICARDO, David. Princípios de economia política e tributação. Trad. Paulo Sandroni. São Paulo: Editora Nova Cultural, 1996.

ROSANVALLON, Pierre. O Liberalismo Econômico: história da idéia de mercado. Trad. Antonio Penalves Rocha. Bauru: EDUSC, 2002.

SADER, Emir. Estado e política em Marx. São Paulo: Cortez, 1998.

SAES, Décio. Estado capitalista e classe dominante. In: Crítica Marxista, n.12, 2001.

SARAIVA, José F. S (org.). História das relações internacionais contemporâneas: da sociedade internacional do século XIX à era da globalização. São Paulo: Saraiva, 2007.

SCHLESSENER, Anita Helena. Hegemonia e cultura em Gramsci. 3. ed. Curitiba: Ed. UFPR, 2007.

SCHOULTZ, Lars. Estados Unidos: poder e submissão: uma história da política norte americana em relação à América Latina. Trad. Raul Fiker. Bauru: EDUSC, 2000.

SCREPANTI, Ernesto \& ZAMAGNI, Stefano. An Outline of the History of Economic Thought. Oxford: Oxford University Press, 2005.

SECCO, Lincoln. Gramsci e a Revolução. São Paulo: Alameda, 2006.

SILVA, Francisco C. T. da; MEDEIROS, Sabrina E. ; VIANNA, Alexander M. (orgs.). Dicionário crítico do pensamento da direita: idéias instituições e personagens. Rio de Janeiro: FAPERJ: MAUAD, 2000.

SILVA, Ricardo. Ideologia de Estado e autoritarismo no Brasil. In: Cadernos de Pesquisa PPGSP/UFSC, n. 21, junho 2000.

SILVA, Sérgio. Expansão cafeeira e origens da indústria no Brasil. São Paulo: AlfaÔmega, 1976.

SILVA, Kalina V. e SILVA, Maciel H. Dicionário de conceitos históricos. $2^{\mathrm{a}}$ ed. São Paulo: Contexto, 2006.

SIMONSEN, Roberto C. Evolução Industrial do Brasil e outros estudos. São Paulo: Cia. Editora Nacional, 1975.

SILVA, Sérgio S. Expansão Cafeeira e Origens da Indústria no Brasil. São Paulo: AlfaOmega, 1985. 
SKIDMORE, Thomas. Brasil: de Getúlio a Castelo (1930-1964). 5ª Ed. São Paulo: Paz e Terra, 1976.

SUZIGAN, Wilson. Indústria brasileira: origens e desenvolvimento. São Paulo: Brasiliense, 1986.

SZMRECSÁNYI, Tamás. História econômica, teoria econômica e economia aplicada. In: História econômica \& história de empresas XI. 2 (2008), 21-30 . e GRANZIERA, Rui G. (orgs.). Getúlio Vargas e a economia contemporânea. Campinas: Editora da Unicamp, 2004.

THOMPSON, Edward P. A formação da classe operária inglesa. $1^{\mathrm{a}}$ ed. Rio de Janeiro: Paz e Terra, 1987.

A miséria da teoria ou um planetário de erros: uma crítica ao pensamento de Althusser. Rio de Janeiro: Zahar Editores, 1981.

VITORINO, Arthur J. R. Notas sobre a teoria da formação de classe em E. P. Thompson. In: Historia Social. Campinas: No 4/5 1997/1998, p. 157-173.

WEBER, Max. Ciência e Política: Duas vocações. São Paulo: Martin Claret, 2005.

WEFFORT, Francisco C. Formação do pensamento político brasileiro: idéias e personagens. São Paulo, Ática, 2006.

WIRTH, John D. A politica do desenvolvimento na era de Vargas. Trad. Jefferson Barata. Rio de Janeiro: Fundação Geúlio Vargas, 1973.

WOOD, Ellen Meiksins. Democracia contra capitalismo: a renovação do materialismo histórico. São Paulo: Boitempo, 2003, p. 27-72.

Site do Centro de Pesquisa e Documentação Histórica da Fundação Getúlio Vargas do Rio de Janeiro. URL: http://www.cpdoc.fgv.br/ 